\title{
Improved Energy Efficiency and Fuel Substitution in the Iron and Steel Industry
}

MARIA T. JOHANSSON

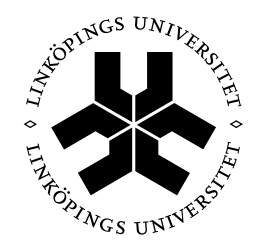

\section{Linköping University INSTITUTE OF TECHNOLOGY}

Division of Energy Systems

Department of Management and Engineering

LINKÖPING UNIVERSITY

SE-581 83 Linköping, Sweden

Linköping, April 2014 
Improved energy efficiency and fuel substitution in the iron and steel industry MARIA T. JOHANSSON

(C) MARIA T. JOHANSSON, 2014

Linköping Studies in Science and Technology

Dissertation No. 1586

ISBN 978-91-7519-367-0

ISSN 0345-7524

Distributed by:

LINKÖPING UNIVERSITY

Department of Management and Engineering

SE-581 83 Linköping

Sweden

Phone: +46 (0)13-28 1000

Printed by:

LiU-Tryck, Linköping, Sweden, 2014

Cover photography:

Pig iron poured from the blast furnace at SSAB Strip Products, Luleå, Sweden. Photograph taken by Stig-Göran Nilsson, 2002. Jernkontoret's picture archive. Steel mill silhouette at Redcar, England, UK.

Photograph taken by Michael Marston. www.flickr.com, license:

creativecommons.org/licenses/by/2.0/

Cover design:

Tomas Hägg, LiU-Tryck, Linköping, Sweden 
This thesis is based on work conducted within the interdisciplinary graduate school Energy Systems. The national Energy Systems Programme aims at creating competence in solving complex energy problems by combining technical and social sciences. The research programme analyses processes for the conversion, transmission and utilisation of energy, combined together in order to fulfil specific needs.

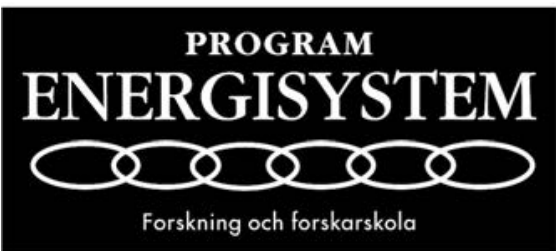

The research groups that constitute the Energy Systems Programme are the Department of Engineering Sciences at Uppsala University, the Division of Energy Systems at Linköping Institute of Technology, the Research Theme Technology and Social Change at Linköping University, the Division of Heat and Power Technology at Chalmers University of Technology in Göteborg as well as the Division of Energy Processes at the Royal Institute of Technology in Stockholm. Associated research groups are the Division of Environmental Systems Analysis at Chalmers University of Technology in Göteborg as well as the Division of Electric Power Systems at the Royal Institute of Technology in Stockholm.

www.liu.se/energi 


\section{ABSTRACT}

IPCC reported in its climate change report 2013 that the atmospheric concentrations of the greenhouse gases (GHG) carbon dioxide $\left(\mathrm{CO}_{2}\right)$, methane, and nitrous oxide now have reached the highest levels in the past 800,000 years. $\mathrm{CO}_{2}$ concentration has increased by $40 \%$ since pre-industrial times and the primary source is fossil fuel combustion. It is vital to reduce anthropogenic emissions of GHGs in order to combat climate change. Industry accounts for $20 \%$ of global anthropogenic $\mathrm{CO}_{2}$ emissions and the iron and steel industry accounts for $30 \%$ of industrial emissions. The iron and steel industry is at date highly dependent on fossil fuels and electricity. Energy efficiency measures and substitution of fossil fuels with renewable energy would make an important contribution to the efforts to reduce emissions of GHGs.

This thesis studies energy efficiency measures and fuel substitution in the iron and steel industry and focuses on recovery and utilisation of excess energy and substitution of fossil fuels with biomass. Energy systems analysis has been used to investigate how changes in the iron and steel industry's energy system would affect the steel plant's economy and global $\mathrm{CO}_{2}$ emissions. The thesis also studies energy management practices in the Swedish iron and steel industry with the focus on how energy managers think about why energy efficiency measures are implemented or why they are not implemented. Indepth interviews with energy managers at eleven Swedish steel plants were conducted to analyse energy management practices.

In order to show some of the large untapped heat flows in industry, excess heat recovery potential in the industrial sector in Gävleborg County in Sweden was analysed. Under the assumptions made in this thesis, the recovery output would be more than three times higher if the excess heat is used in a district heating system than if electricity is generated. An economic evaluation was performed for three electricity generation technologies for the conversion of low-temperature industrial excess heat. The results show that electricity generation with organic Rankine cycles and phase change material engines could be profitable, but that thermoelectric generation of electricity from low-temperature industrial excess heat would not be profitable at the present stage of technology development. With regard to fossil fuels substituted with biomass, there are opportunities to substitute fossil coal with charcoal in the blast furnace and to substitute liquefied petroleum gas (LPG) with bio-syngas or bio synthetic natural gas (bio-SNG) as fuel in the steel industry's reheating furnaces. However, in the energy market scenarios studied, substituting LPG with bio-SNG as fuel in reheating furnaces at the studied scrap-based steel plant would not be profitable without economic policy support. The development of the energy market is shown to play a vital role for the outcome of how different measures would affect global $\mathrm{CO}_{2}$ emissions.

Results from the interviews show that Swedish steel companies regard improved energy efficiency as important. However, the majority of the interviewed energy managers only worked part-time with energy issues and they experienced that lack of time often was a barrier for successful energy management. More efforts could also be put into engaging and educating employees in order to introduce a common practice of improving energy efficiency at the company. 


\section{SAMMANFATTNING}

Halterna av växthusgaserna koldioxid $\left(\mathrm{CO}_{2}\right)$, metan och kväveoxider har under de senaste 800000 åren aldrig varit högre i atmosfären än vad de är idag. Detta resultat redovisades i IPCCs klimatrapport år 2013. $\mathrm{CO}_{2}$-koncentrationen har ökat med 40 \% sedan förindustriell tid och denna ökning beror till största delen på förbränning av fossila bränslen. Ökade koncentrationer av växthusgaser leder till högre global medeltemperatur vilket i sin tur resulterar i klimatförändringar. För att bromsa klimatförändringarna är det viktigt att vi arbetar för att minska utsläppen av växthusgaser. Industrin står för $20 \%$ av de globala utsläppen av $\mathrm{CO}_{2}$ och järn- och stålindustrin står för $30 \%$ av industrins utsläpp. Järn- och stålindustrin är i dag till stor del beroende av fossila bränslen och el för sin energiförsörjning. Energieffektiviseringsåtgärder och byte av fossila bränslen mot förnybar energi i järn- och stålindustrin skulle kunna bidra till minskade utsläpp av växthusgaser.

Denna avhandling studerar åtgärder för effektivare energianvändning och möjligheter för bränslebyte i järn- och stålindustrin. Avhandlingen fokuserar på återvinning och utnyttjande av överskottsenergier och ersättning av fossila bränslen med biomassa. Energisystemanalys har använts för att undersöka hur förändringar i järn- och stålindustrins energisystem skulle påverka ekonomin och de globala utsläppen av $\mathrm{CO}_{2}$. Avhandlingen studerar också betydelsen av energiledning och nätverkande för att uppnå en effektivare energianvändning. Fokus har här varit på att studera hur energiansvariga resonerar kring varför energieffektiviseringsåtgärder genomförs eller varför de inte genomförs. Djupintervjuer med energiansvariga vid elva svenska stålverk genomfördes för att analysera denna fråga.

För att ge ett exempel på den stora outnyttjade potentialen av överskottsvärme från industrin analyserades potentialen i Gävleborgs län. Möjligheterna att använda överskottsvärmen som fjärrvärme eller för att producera el analyserades. Här visar resultaten att fjärrvärmeproduktionen skulle bli mer än tre gånger så stor som elproduktionen. En ekonomisk utvärdering gjordes där tre tekniker för produktion av el från lågtempererad industriell överskottsvärme jämfördes. Resultaten visar att elproduktion med organisk Rankine-cykel eller en så kallad fasändringsmaterialmotor kan vara lönsam, men att termoelektrisk elproduktion inte är lönsam med dagens teknik och prisnivåer. Det är möjligt att ersätta en del av det fossila kolet i masugnen med träkol och på detta sätt introducera förnybar energi i stålindustrin. Man kan också ersätta gasol som används som bränsle i stålindustrins värmningsugnar med syntesgas eller syntetisk naturgas (SNG) som produceras genom förgasning av biomassa. Under de antaganden som gjorts i avhandlingen skulle det dock inte vara lönsamt för det skrotbaserade stålverk som studerats att ersätta gasolen med bio-SNG. För att uppnå lönsamhet behövs i detta fall ekonomiska styrmedel. Hur olika åtgärder påverkar de globala utsläppen av $\mathrm{CO}_{2}$ beror till stor del på hur framtidens energimarknad ser ut. Elproduktion från industriell överskottsvärme skulle minska de globala $\mathrm{CO}_{2}$-utsläppen i alla scenarier som studerats, men för de andra åtgärderna varierar resultaten beroende på vilka antaganden som gjorts. Resultaten från intervjustudien visar att svensk stålindustri anser att energifrågan är viktig, men det finns fortfarande mycket att göra för att effektivisera energianvändningen i denna sektor. Flera av de intervjuade arbetade bara deltid med energifrågor och de upplevde att tidsbrist hindrade dem från ett effektivt energiledningsarbete. En rekommendation till företagen är därför att anställa en energiansvarig på heltid och/eller 
fler personer som kan arbeta med energifrågor. Det bör också läggas mer resurser på att engagera och utbilda anställda för att på så sätt introducera en företagskultur som främjar effektiv energianvändning. 
Ora my framily 
"All men by nature desire knowledge"

- Aristotle (384 BC-322 BC)

"Our problems are man-made; therefore they may be solved by man. Na problem of human destiny is beyond human beings"

- John 7. Kennedy (1917-1963)

$\mathrm{xi}$ 


\section{Appended papers}

This thesis is based on the work described in the following papers. The papers are not listed in chronological order based on date of publishing, but rather in the order that follows the order of the research questions of this thesis.

I. Maria T. Johansson, Mats Söderström

Options for the Swedish steel industry - Energy efficiency measures and fuel conversion

Energy 2011; 36:191-198, Elsevier

II. Sarah Broberg Viklund, Maria T. Johansson

Technologies for utilization of industrial excess heat - potentials for energy recovery and $\mathrm{CO}_{2}$ emission reduction

Energy Conversion and Management 2014; 77:369-379, Elsevier

III. Maria T. Johansson, Mats Söderström

Electricity generation from low-temperature industrial excess heat - an opportunity for the steel industry

Energy Efficiency 2014; 7(2):203-215, Springer

IV. Maria T. Johansson, Mats Söderström

Bio-syngas as fuel in the steel industry's heating furnaces - a case study on feasibility and $\mathrm{CO}_{2}$ mitigation effects

Proceedings of the International Conference on Efficiency, Cost, Optimization, Simulation and Environmental Impact of Energy System (ECOS) 2011, Novi Sad, Serbia, July 4-7, 2011.

V. Maria T. Johansson

Bio-synthetic natural gas as fuel in steel industry reheating furnaces - A case study of economic performance and effects on global $\mathrm{CO}_{2}$ emissions

Energy 2013; 57:699-708, Elsevier

VI. Maria T. Johansson

Improved energy efficiency within the Swedish steel industry - the importance of energy management and networking

Submitted to Energy Efficiency, Springer 


\section{Acknowledgements}

This project has been part of the Energy Systems Programme, which is financed by the Swedish Energy Agency. Additional funding has been provided by Stiftelsen den Göranssonska fonden which is a trust fund. The fund was established by Göran Fredrik Göransson, the founder of the steel company Sandvik AB. I gratefully acknowledge them for the financial support.

I would like to express my gratitude to Professor Bahram Moshfegh, for giving me the opportunity to be a PhD student at the Division of Energy Systems. I took my scooter to the job interview, but the weather was terrible and extremely windy and I almost ended up in a ditch. I arrived at Linköping University a bit late and out of breath. However, Bahram was very understanding and despite my late arrival the interview turned out well and I got the offer to be a member of the Energy Systems team.

Many people have enriched my time as a $\mathrm{PhD}$ student. First, I would like to thank my supervisor Associate Professor Mats Söderström for his guidance, support and encouraging pep talks. I would also like to thank my co-supervisors Associate Professor Magnus Karlsson and Professor Jenny Palm. Magnus introduced me to the modelling tool reMIND and even though I did not use the tool in this thesis, I could come across problems in the future where the tool could be of use. Jenny has been a great support during my interview study. It was a new experience for me, as an engineer, not to be able to quantify my results and Jenny guided me through the area of qualitative research methods.

Thank you to all my colleagues at the Division of Energy System for good cooperation, enjoyable coffee breaks and fun evening activities. I would especially like to thank Elisabeth Larsson for her help with administrative issues and for all our private talks about children, travels and food, and to Danica Djuric Ilic for always encouraging me and being the perfect neighbour in the corridor and for taking me to nice and tasty lunches. Thanks also to Sarah Broberg Viklund for stimulating discussions and good cooperation during the process of writing our paper and to Jakob Rosenqvist for help with measurement issues. Jakob, I am glad that you share my need for regular meals and I enjoyed our three-course dinners on the train between Linköping and Sandviken.

My years as a $\mathrm{PhD}$ student have been very inspiring and I have learned so much. I especially appreciated being a member of the Energy Systems Programme, which gave me the opportunity to meet and collaborate with researchers and PhD students from other universities and other academic disciplines. I would like to thank all D08 for the great time during our mandatory course period. Special thanks to Daniella Johansson, Kersti Karltorp, Hanna Ljungstedt and Julia Schwabecker for good collaboration and enjoyable time during the work with our multidisciplinary project report. Daniella, Kersti and Hanna, you always made my stays in Gothenburg a joy.

Many thanks to the personnel at Sandvik AB in Sandviken who provided information and knowledge that was invaluable for my research. In particular, I would like to thank Susanne Lindqvist, my contact person at Sandvik AB, for always being available when I had questions. Your cheerful and helpful nature made my visits to Sandviken a pure 
pleasure. Thanks also to Mats Johansson who helped me with the installation of measurement equipment and provided production statistics.

I am very grateful that the respondents took their time to meet me and answer my questions. Without them there would not have been a study on energy management.

I would like to express my gratitude to Adjunct Professor Mikael Larsson for reading and commenting the draft of my thesis. His knowledge about the iron and steel industry's processes and its energy flows was valuable help for me in my work to finalize the thesis. Many thanks also to my colleagues at the Division of Energy Systems who provided insightful feedback on the thesis.

Last but not least I would like to thank my family for always believing in me and for setting my mind on other things than work. All my love to my husband Jörgen and to our wonderful children Ida, Ylva and Oskar. You are the centre of my world! 


\section{Thesis outline}

This thesis gives an introduction to and a summary of the six appended papers. The thesis' outline is as follow:

Chapter 1 gives an introduction to the conducted research and poses the aim and research questions. An overview of the appended papers and co-author statement are presented.

Chapter 2 is the first chapter in the background part. This chapter presents the iron and steel industry, its production processes, energy use and $\mathrm{CO}_{2}$ emissions.

Chapter 3 presents previous research about measures for improving energy efficiency in the iron and steel industry and options to substitute fossil fuels with biomass. The chapter gives a background to the issue of industrial excess heat and options to recover the heat. Heat-driven electricity production is described.

Chapter 4 describes the processes of biomass gasification and presents an overview of present European biomass gasification projects. Previous studies of integration of biomass gasification with industry are presented.

Chapter 5 describes different methods of assessing $\mathrm{CO}_{2}$ emissions from electricity and biomass use.

Chapter 6 presents theory about energy management in industry and barriers to and driving forces for improving industrial energy efficiency. European directives and policy instruments affecting the European iron and steel industry are described.

Chapter 7 describes the systems studied in this thesis.

Chapter 8 presents the methodologies used.

Chapter 9 presents a summary and analysis of the results from the appended papers.

Chapter 10 discusses the results.

Chapter 11 provides conclusions of the thesis.

Chapter 12 gives suggestions for further work. 


\section{Abbreviations}

AOD

ASU

BAT Best available technology

BF $\quad$ Blast furnace

BFG Blast furnace gas

BG Biomass gasification

BOF Basic oxygen furnace

CCP Coal condensing power

CCS Carbon capture and storage

CFB Circulated fluidized bed

CHP Combined heat and power

COG Coke oven gas

CRF Capital recovery factor

CDQ Coke dry quenching

DH District heating

DHS District heating system

DME Dimethyl ether

DR Direct reduction

DRI Direct reduced iron

EAF Electric arc furnace

EED
Energy efficiency directive
EMS Energy market scenarios

ENPAC Energy price and carbon balance

EU ETS The European Union emissions trading system

FT Fischer Tropsch

GHG Greenhouse gas

HOB Heat-only boiler

IED Industrial emissions directive

LPG Liquefied petroleum gas

$\mathbf{M W}_{\text {th }} \quad$ Megawatt thermal

NAP Net annual profit

NGCC Natural gas combined cycle

NPV Net present value

ORC Organic Rankine cycle

PCM Phase change material

PDCA Plan-Do-Check-Act

SNG Synthetic natural gas

TEG Thermoelectric generator

TES Thermal energy storage

TPV Thermophotovoltaic

TRT Top pressure recovery turbine

ULCOS Ultra-low carbon dioxide steelmaking 


\section{Table of Contents}

1 Introduction $\quad 1$

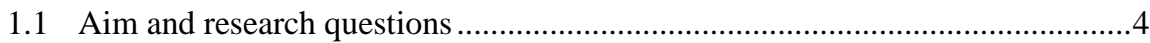

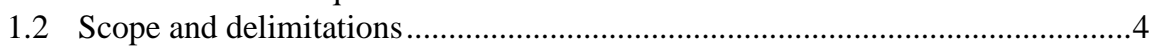

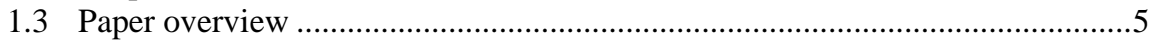

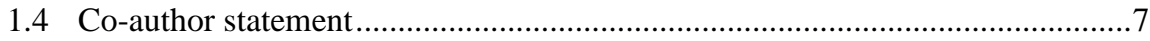

1.5 Other publications not included in the thesis.................................................

$2 \quad$ Iron and steel industry $\quad 9$

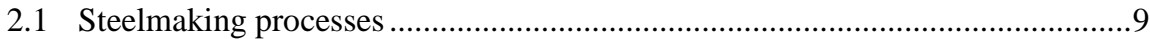

2.2 Energy use and $\mathrm{CO}_{2}$ emissions in the iron and steel industry .........................11

2.3 New technologies for steelmaking............................................................... 14

$3 \quad$ Energy efficiency and fuel substitution $\quad \mathbf{1 5}$

3.1 Energy efficiency potential in existing steel plants .........................................15

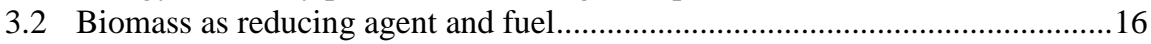

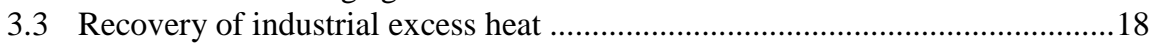

3.4 Electricity production from excess heat ......................................................19

4 Biomass gasification $\quad 25$

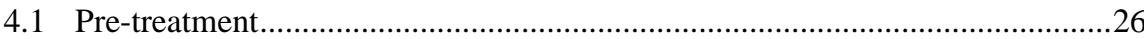

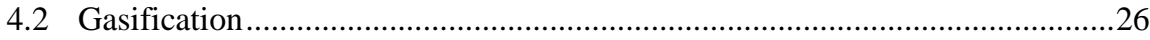

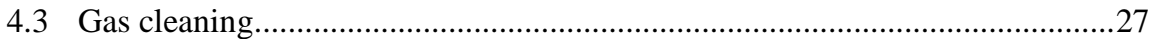

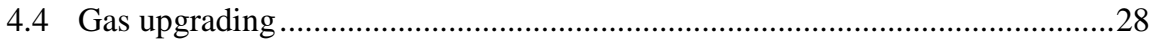

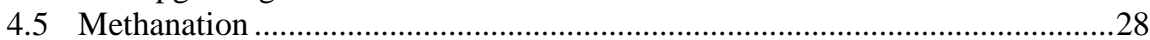

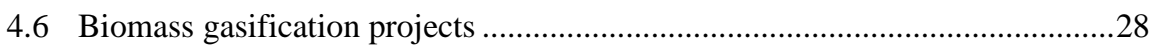

4.7 Integration of biomass gasification with industry ........................................29

5 Assessment of $\mathrm{CO}_{2}$ emissions 31

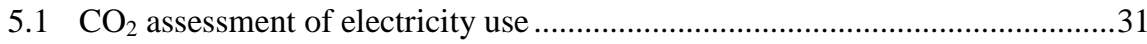

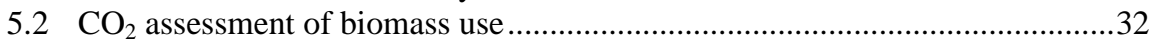

$6 \quad$ Energy management in industry 33

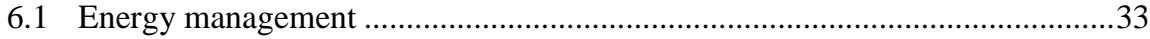

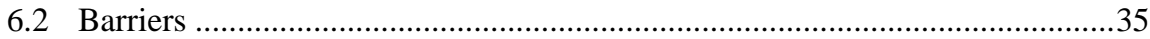

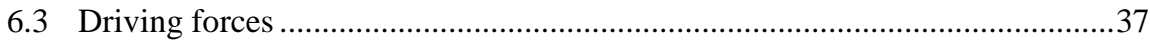

6.3.1 European directives and policy instruments ......................................39

7 Systems studied $\quad 43$

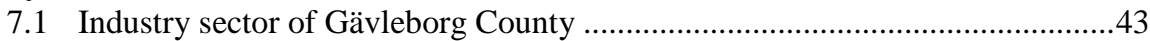

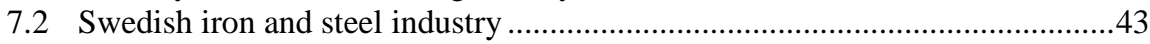

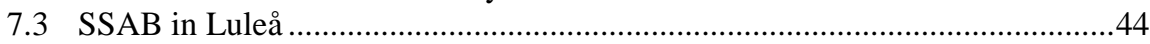

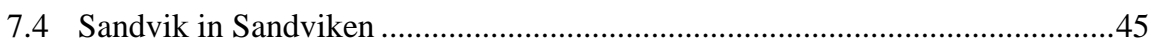

7.4.1 Gasification and methanation system at Sandvik in Sandviken ............45

8 Methodology $\quad 47$

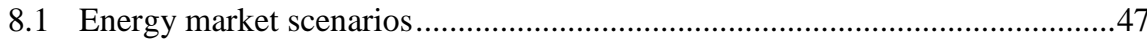

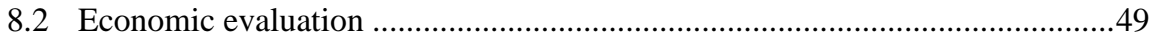




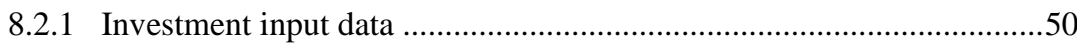

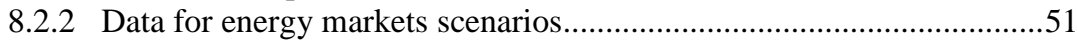

$8.3 \mathrm{CO}_{2}$ emissions evaluation and input data ..................................................52

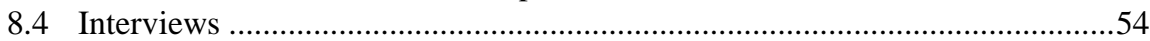

$9 \quad$ Results and analysis $\quad 55$

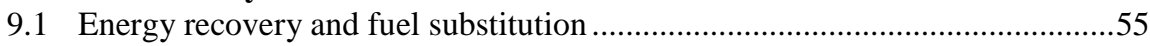

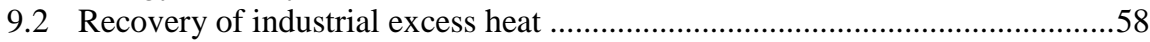

9.2.1 Economic evaluation of electricity production from low-temperature

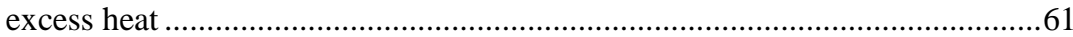

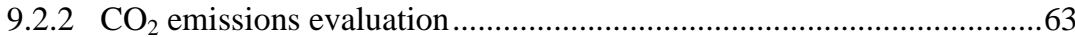

9.3 Bio-syngas and bio-SNG as fuel in reheating furnaces ..................................65

9.3.1 Economic evaluation of bio-SNG as fuel in reheating furnaces ...........65

9.3.2 $\mathrm{CO}_{2}$ emissions evaluation....................................................................68

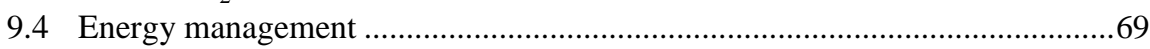

$\begin{array}{lll}10 & \text { Discussion } & 73\end{array}$

11 Conclusions $\quad 77$

12 Further work $\quad 81$

$\begin{array}{lc}\text { References } & 83\end{array}$

$\begin{array}{lr}\text { Appendix } 1 & 95\end{array}$ 


\section{Introduction}

This chapter begins with a short introduction to the thesis. Then the chapter continues with the aim of the thesis, a description of the research questions posed, the scope of the thesis and the delimitations of the appended papers on which this thesis is based. The chapter ends with an overview of the appended papers.

Global climate change and anthropogenic greenhouse gas (GHG) emissions have during the last decade attracted increased attention. The main GHGs are carbon dioxide $\left(\mathrm{CO}_{2}\right)$, methane $\left(\mathrm{CH}_{4}\right)$, nitrous oxide $\left(\mathrm{N}_{2} \mathrm{O}\right)$, and fluorinated gases (EPA, 2011). Total global primary energy supply was $148.5 \mathrm{PWh}$ and global $\mathrm{CO}_{2}$ emissions from fuel combustion was 30.3 Gtonnes in 2010 (IEA, 2012a). Forty-three percent of these emissions originated from coal, $36 \%$ from oil and $20 \%$ from gas. Industry accounted for $20 \%$ of the global $\mathrm{CO}_{2}$ emissions, see Figure 1. In 2011, total Swedish primary energy supply was 577 TWh (Swedish Energy Agency, 2013a). Total Swedish emissions of GHGs were 61.4 million tonnes of $\mathrm{CO}_{2}$ equivalents $\left(\mathrm{CO}_{2}\right.$-eq) and $\mathrm{CO}_{2}$ emissions were 48.7 million tonnes (Swedish Environmental Protection Agency, 2013b). The industry sector accounted for 26\% of the Swedish GHG emissions, see Figure 2.

To cut the trend of increased concentrations of GHGs in the atmosphere and to combat global climate change, fossil fuel combustion must decrease. This could be accomplished through energy efficiency measures, which reduce the demand for primary energy, and by conversion to renewable energy sources. In recent years, governments have increased their efforts to address energy-related environmental issues (IEA, 2012a). As an example, the European Commission has set a goal for 2020 to reduce GHG emissions by $20 \%$ compared to the 1990 level and to improve energy efficiency by 20\% compared to 2005 (Eurostat, 2013). The share of renewable energy sources in final energy use should increase to $20 \%$. 


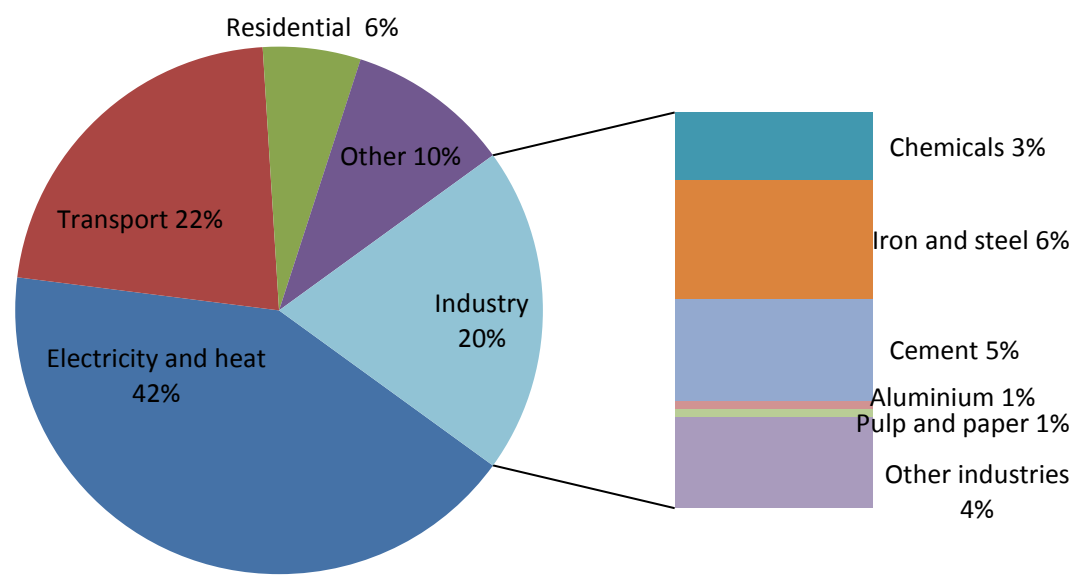

Figure 1. World $\mathrm{CO}_{2}$ emissions by sector in 2010 (IEA, 2012a; IEA, 2010). "Other" includes commercial/public services, agriculture/forestry, fishing, energy industries other than electricity and heat generation, and other emissions not specified elsewhere.

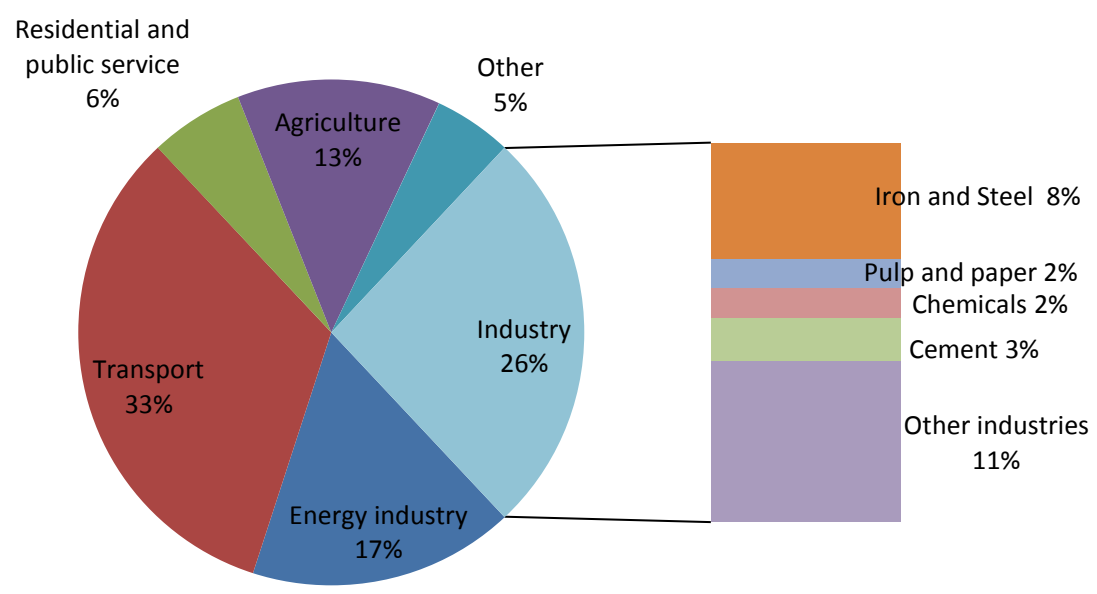

Figure 2. Emissions of GHGs $\left(\mathrm{CO}_{2}\right.$-eq) by sector in Sweden 2011 (Swedish Environmental Protection Agency, 2013a; Swedish Environmental Protection Agency, 2013b). “Other” includes military, solvent use, and waste disposal. 
World crude steel production was 1.6 billion tonnes in 2013 (Worldsteel Association, 2014). The iron and steel industry is energy-intensive and consumes large amounts of fossil fuels and electricity. This industry sector accounted for $6 \%$ of total global $\mathrm{CO}_{2}$ emissions (IEA, 2013a). The iron and steel industry in Sweden produced 4.4 million tonnes of crude steel in 2013 (Jernkontoret, 2014b) and accounted for about 8\% of the Swedish GHG emissions (Swedish Environmental Protection Agency, 2013a). To meet policy demands and to maintain competiveness it is important for the iron and steel industry to improve energy efficiency and to reduce the dependency on fossil fuels. It is important that the primary energy demand is reduced and that excess energy generated in industrial processes is recovered and utilised. Recovery of excess heat should be done after any other energy conservation measures have been taken. Large amounts of heat are generated in steel production processes and recovering the excess heat would result in more efficient use of energy resources. Several Swedish steel companies export some of their excess heat to district heating systems (DHS), but there is additional heat not being recovered today. Substituting fossil fuels with biomass would introduce a renewable fuel into the steelmaking process. The first blast furnaces (BF) used charcoal to produce iron, but in the nineteenth-century they started to use fossil coal in the form of coke instead. The coke was cheaper and could allow for larger BF because coke is harder than charcoal and can sustain heavier weights without causing a collapse of the bed structure in the BF. Additionally, countries with scarce forest resources could produce steel on a large scale and compete on the world market. Today, the interest in charcoal production to the BF process has increased, due to the climate change debate. Besides the $\mathrm{BF}$, reheating furnaces use large quantities of fossil fuels. Firing these furnaces with biofuels would offer an additional opportunity for the steel industry to reduce the dependency on fossil fuels and reduce its emissions of fossil $\mathrm{CO}_{2}$. However, biomass is a limited resource and when the demand for the resource increases it is important that it is efficiently utilised. This highlights the need for systems analysis in which alternative use of the biomass resources is examined. Moreover, there are other concerns with regard to biomass that have to be considered before implementing a fuel substitution, e.g. structural heterogeneity of biomass, mass density, ash content, energy density, volatile matter and oxygen content.

Even though technologies, methods and processes for saving energy in industry exist, there are barriers that sometimes prevent their implementation. The gap between current or expected future energy use and the optimal current or future energy use is called the energy efficiency gap (Jaffe and Stavins, 1994). It is not obvious that companies act economically rational and the paradox of cost-effective technologies not being implemented is known as the energy efficiency paradox. The research about barriers to and driving forces for implementing energy efficiency measures is important when developing action plans that could reduce the energy efficiency gap.

In this thesis, energy systems analysis has been used to investigate how changes in the iron and steel industry's energy system would affect the steel plant's economy and global $\mathrm{CO}_{2}$ emissions. Besides techno-economic aspects, the thesis also analyses organisational and behavioural aspects of improving energy efficiency in the steel industry. 


\subsection{Aim and research questions}

The aim of this thesis is to analyse opportunities for the iron and steel industry to become more energy efficient and to reduce global $\mathrm{CO}_{2}$ emissions. The thesis studies technical measures for improved energy efficiency and reduced $\mathrm{CO}_{2}$ emissions, and the importance of energy management and networking for the implementation of energy efficiency measures. The study of technical measures focuses on two pathways: recovery of excess energy and in particular excess heat, and substitution of fossil fuels with biomass.

Five research questions guide the analysis:

1. Which technologies could be used to recover excess energy from the steel industry?

2. Could electricity generation from low-temperature excess heat be profitable?

3. Would it be technically and economically feasible for a steel plant to substitute fossil fuels with biomass?

4. How would recovery and utilisation of excess heat, and fuel substitution affect global $\mathrm{CO}_{2}$ emissions?

5. Why are energy efficiency measures implemented or why are they not implemented in the Swedish iron and steel industry?

Table 1 shows which research question is investigated in which of the appended papers.

Table 1 . The table shows in which of the appended papers the research questions are investigated.

\begin{tabular}{ll} 
Research question & Paper \\
\hline 1 & I, II, III \\
2 & III \\
3 & IV, V \\
4 & II, III, IV, V \\
5 & VI \\
\hline
\end{tabular}

\subsection{Scope and delimitations}

This thesis is based on systems studies of energy efficiency measures and fuel substitution in the Swedish iron and steel industry. The focus is on recovery and utilisation of excess energy and substitution of fossil fuels with biomass. The thesis also 
studies energy management practices in the Swedish iron and steel industry with the focus on how energy managers reason about why energy efficiency measures are implemented or why they are not implemented.

In the economic studies, required investments for auxiliary equipment, such as new distribution systems, were not included in the analysis. These costs are site-specific and the results in this thesis present investment opportunities for such investments.

In the study of production of bio-syngas and bio-SNG to the steel plant's reheating furnaces, only wood fuel pellets was considered as feedstock to the gasifier.

In the analysis of GHG emissions, only $\mathrm{CO}_{2}$ emissions were considered since they represent the major part of the iron and steel industry's GHG emissions (World Steel Association, 2012b). Moreover, $\mathrm{CO}_{2}$ is the most important anthropogenic GHG in the atmosphere and contributes approximately $64 \%$ to radiative forcing by long-lived GHGs (WMO, 2013). 1990 to 2012 radiative forcing by long-lived GHGs increased by 32\% and $\mathrm{CO}_{2}$ accounted for $80 \%$ of this increase.

Externalities such as health benefits and other environmental impact besides $\mathrm{CO}_{2}$ emissions were not included in the analysis.

The studied systems are Swedish, but the energy systems analysis has a European perspective because it was assumed that in the time frame studied there will be a European market for electricity and fuels. However, the market for heat will be local and therefore two different DHS were analysed, representing a small Swedish heat system and a large Swedish heat system respectively.

\subsection{Paper overview}

This thesis is based on the following six papers.

\section{Paper I}

Maria Johansson, Mats Söderström

Options for the Swedish steel industry - Energy efficiency measures and fuel conversion

Energy 2011; 36:191-198, Elsevier

This paper identifies different options for the iron and steel industry to improve energy efficiency and reduce $\mathrm{CO}_{2}$ emissions. The paper investigates technologies for efficient energy use and technologies for substitution of fossil fuels with renewable alternatives. Options are presented for iron ore-based as well as scrap-based steel production. Excess energy can e.g. be used for electricity generation, space heating, production of syngas from coke oven gas and heat delivery to district heating systems or other facilities in an industrial symbiosis. Reductions in $\mathrm{CO}_{2}$ emissions if fuel substitution is implemented are calculated for two Swedish steel plants, one iron ore-based and one scrap-based. The study showed that there are great potentials to reduce direct emissions of $\mathrm{CO}_{2}$. 


\section{Paper II}

Sarah Broberg Viklund, Maria Johansson

Technologies for utilization of industrial excess heat - potentials for energy recovery and $\mathrm{CO}_{2}$ emission reduction

Energy Conversion and Management 2014; 77:369-379, Elsevier

This paper presents technologies for recovery and utilisation of industrial excess heat. The technologies are divided into four categories: heat harvesting technologies, heat storage technologies, heat utilisation technologies, and heat conversion technologies. Conversion efficiency, temperature of heat source, medium of heat source and stage of development are studied. Industrial excess heat utilisation potential in Gävleborg County and its effects on global $\mathrm{CO}_{2}$ emissions are calculated.

\section{Paper III}

Maria Johansson, Mats Söderström

Electricity generation from low-temperature industrial excess heat - an opportunity for the steel industry

Energy Efficiency 2014; 7(2):203-2015, Springer

In this paper three technologies for generation of electricity from low-temperature industrial excess heat are compared and evaluated. The technologies chosen for evaluation are thermoelectric generator (TEG), organic Rankine cycle (ORC) and phase change material engine (PCM-engine). The technologies are evaluated with regard to preferred temperature range of heat source, efficiency, capacity and economy. Potential electricity production from low-temperature excess heat from a steel plant is calculated. Reductions in global $\mathrm{CO}_{2}$ emissions as a result of this electricity production are presented.

\section{Paper IV}

Maria Johansson, Mats Söderström

Bio-syngas as fuel in the steel industry's heating furnaces - a case study on feasibility and $\mathrm{CO}_{2}$ mitigation effects

Proceedings of ECOS 2011, Novi Sad, Serbia, July 4-7, 2011.

This paper is a feasibility study of the substitution of LPG with bio-syngas as fuel in steel industry reheating furnaces. Effects on $\mathrm{CO}_{2}$ emissions in case of a fuel substitution are also calculated. Two cases are studied: a full-scale fuel substitution and a partial fuel substitution. A fuel substitution would require larger gas flows and therefore gas distribution systems and exhaust gas cleaning systems must be dimensioned to handle larger flows. Moreover, burners in the reheating furnaces have to be replaced with burners designed for gases with low heating value.

\section{Paper V}

Maria Johansson

Bio-synthetic natural gas as fuel in steel industry reheating furnaces - A case study of economic performance and effects on global $\mathrm{CO}_{2}$ emissions

Energy 2013; 57:699-708, Elsevier

In this study four future energy market scenarios predicting 2030 are used to analyse if it could be profitable for the steel plant Sandvik in Sandviken to invest in a biomass gasifier 
and substitute liquefied petroleum gas (LPG) with bio-synthetic natural gas as fuel in the reheating furnaces. Moreover, effects on global $\mathrm{CO}_{2}$ emissions are analysed from a perspective where biomass is considered a limited resource. Results show that investment in a biomass gasifier and fuel substitution would not be profitable in any of the scenarios studied. Effects on global $\mathrm{CO}_{2}$ emissions depend on who is the marginal user of wood fuel.

\section{Paper VI}

Maria Johansson

Improved energy efficiency within the Swedish steel industry - the importance of energy management and networking

Submitted to Energy Efficiency

In this study, energy managers at eleven Swedish steel plants are interviewed in order to investigate energy management practices and to understand why energy efficiency measures are or are not implemented. The study also analyses how networking affects the work with improving energy efficiency. According to the respondents, barriers to improved energy efficiency are e.g. too long a pay-back period, lack of personnel, lack of time, lack of personnel with higher education in the energy field, people with no commitment to energy savings and risk of production disruption. Networking contributed to knowledge transfer and inspiration, but unfortunately lack of time often prevented new ideas from being implemented in practice.

\subsection{Co-author statement}

Paper I and Papers III-VI were written entirely by this thesis author and Mats Söderström contributed valuable comments on the drafts of the papers.

Paper II was planned and written in collaboration with PhD student Sarah Broberg Viklund. The input data about industrial excess heat in Gävleborg County was taken from a questionnaire developed and completed by Sarah Broberg Viklund and Sandra Backlund, Linköping University. All parts of the paper were written jointly with Sarah Broberg Viklund.

The work in Paper I-III and Paper IV was supervised by Associate Professor Mats Söderström. Associate Professor Magnus Karlsson supervised the work in Paper II and Paper V, and Professor Jenny Palm supervised the work in Paper VI.

\subsection{Other publications not included in the thesis}

Hanna Ljungstedt, Daniella Johansson, Maria Johansson, Kersti Karltorp

Options for increased use and refining of biomass - the case of energy-intensive industry in Sweden

Publication in Linköping Electronic Conference Proceedings, No. 57. World Renewable Energy Congress 2011, Linköping, Sweden, May 8-13, 2011. 
Maria T. Johansson, Magnus Karlsson

Bio-SNG as fuel in steel industry heating furnaces - integration of a biomass gasifier with a steel plant.

Proceedings of Asia Steel International Conference 2012, Beijing, China, September 2326, 2012.

Maria Johansson

Systemanalys av industriella symbioser - potentialer för VSM, fallstudier och MIND. (Systems analysis of industrial symbiosis - potentials for VSM, case studies and MIND) In: Karlsson, M \& Palm, J (Eds.) På spaning efter systemteori och tvärvetenskaplig metod.

Arbetsnotat Nr 41. Program Energisystem. Linköping University. 2009. (In Swedish)

Daniella Johansson, Maria Johansson, Kersti Karltorp, Hanna Ljungstedt, Julia Schwabecker

Pathways for increased use and refining of biomass in Swedish energy-intensive industry - Changes in a socio-technical system.

Arbetsnotat Nr 43. Program Energisystem. Linköping University. 2009.

Maria Johansson, Daniella Johansson, Kersti Karltorp, Hanna Ljungstedt.

Räcker biomassan till svensk energiintensiv industri? (Will the amount of biomass be sufficient for Swedish energy-intensive industry?)

Energimagasinet EM7/2011, Årgång 33, 2011. (In Swedish)

Jean-Christian Brunke, Maria T. Johansson, Patrik Thollander

Improving energy efficiency in the Swedish iron and steel industry - barriers, drivers, energy management and energy services

Submitted to Journal of Cleaner Production, Elsevier

Maria T. Johansson, Joakim Wren, Mats Söderström

Quantification and recovery of excess heat from cooling beds: A case study at a steel plant

To be submitted 


\section{Iron and steel industry}

This chapter presents a description of the steelmaking processes, energy use and $\mathrm{CO}_{2}$ emissions in the iron and steel industry and some of the ongoing research on breakthrough technologies for iron and steelmaking.

\subsection{Steelmaking processes}

There are two main routes for the production of steel; iron ore-based steel production and scrap-based steel production. The most common process for iron ore-based steel production in the world is the blast furnace-basic oxygen furnace (BF-BOF) route, but there is also the less common direct reduced iron-electric arc furnace route (DRI-EAF). The most common route for scrap-based steelmaking is the scrap-based EAF route. Twothirds of the steel production in the world uses the BF-BOF route (EIA, 2013). Figure 3 shows a schematic flow sheet over the steel production processes. A steel plant which has all the processes for iron and steelmaking, i.e., coke production, ironmaking, steelmaking, casting and rolling is called an integrated steel mill.

In iron ore-based steelmaking, steel is produced from iron ore. The first step is ironmaking and the main route for iron production is the BF process; 95\% of the world's iron production in 2012 (World Steel Association, 2012a). In the BF process, iron ore is fed to the BF in the form of pellets or sinter, together with coke and limestone. The coke acts as a fuel and a reducing agent in the process when iron oxides in the ore are melted and reduced into liquid iron at high temperatures; there are different reaction zones in a $\mathrm{BF}$ with temperatures ranging between $200^{\circ} \mathrm{C}$ (at the top) and $2100^{\circ} \mathrm{C}$ (at the tuyères ${ }^{1}$ ). Coal in the solid coke and reducing gas reacts with oxygen in the iron oxides forming metallic iron and carbon oxides. Many steel mills inject pulverised coal, natural gas, oil or sometimes plastics into the $\mathrm{BF}$ to reduce the demand for coke and improve energy efficiency of the BF process. However, it is not possible to substitute all of the coke because the coke acts as a physical support material in the BF and ensures gas permeability and process drainage. The added limestone serves as a fluxing agent and removes silica impurities in the iron ore when calcium oxides in the limestone react with silica and silicon dioxide in the iron ore. Limestone, gangue material in the iron ore and ash from the coke form a slag that floats on top of the molten iron. The molten iron dissolves some carbon and also other elements such as silicon, phosphorous and vanadium which comes with the gangue. The liquid iron is transferred to a BOF and

\footnotetext{
${ }^{1}$ Tuyères are the nozzles in the $\mathrm{BF}$ where hot blast (air + additional $\mathrm{O}_{2}$ ) is blown into the furnace together with additional reductants, e.g. pulverised coal, oil or natural gas, to facilitate generation of hot reducing gas.
} 
oxygen is blown into the vessel. The main objective of the BOF process is to reduce the carbon content of the liquid iron. In the process, oxygen reacts with carbon in the liquid iron forming carbon oxides, and when the carbon content of the iron is reduced to below $2 \%$ the iron becomes steel. Silicon, phosphorous and vanadium are also oxidized, forming a slag. Because the decarburisation process is highly exothermic, some amount of steel scrap can be added and melted in the BOF without additional energy supply. The crude steel from the BOF is transferred to ladle metallurgy where the temperature and chemical composition of the steel is adjusted to fit subsequent processes. The steel is then cast and transported to rolling mills for shaping and forming into finished products (Ekerot, 2000).

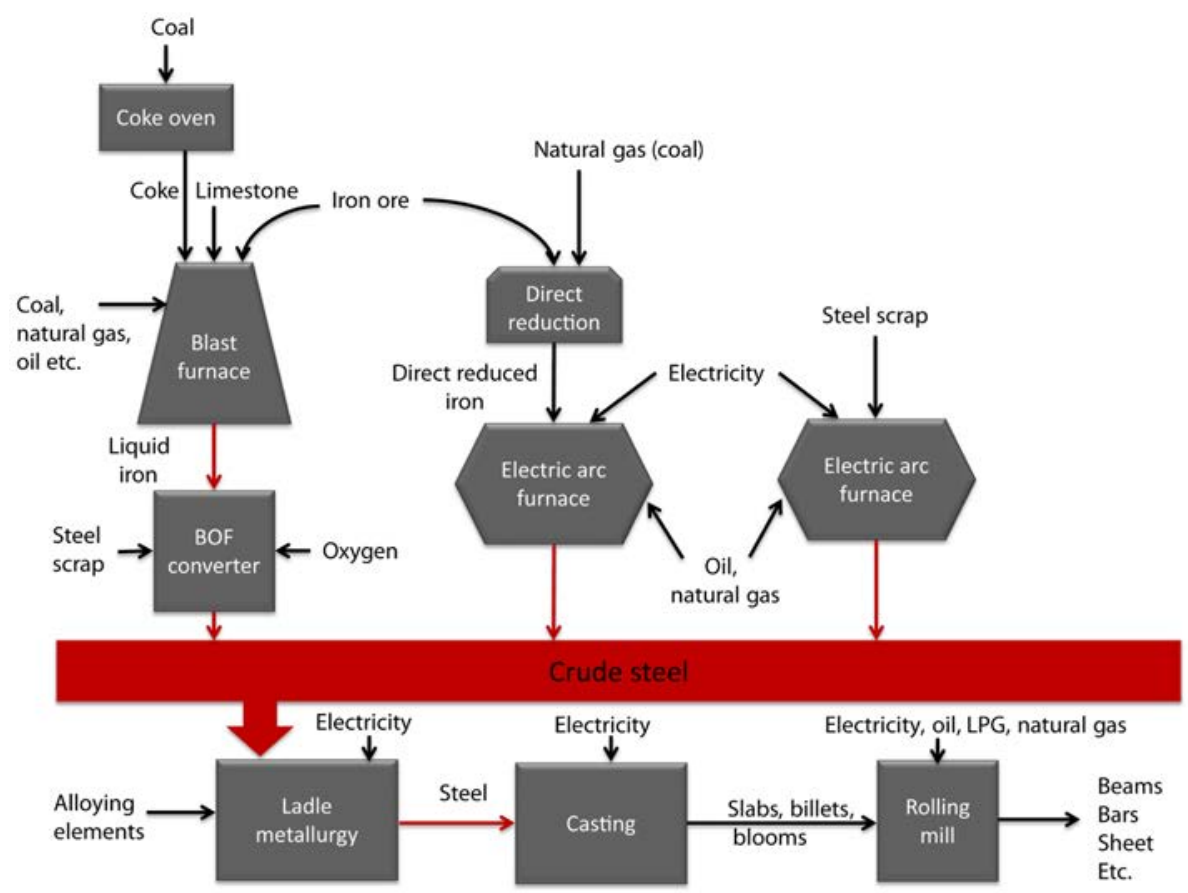

Figure 3. Flow sheet over the steelmaking processes. Steel can be produced from iron ore or from scrap. The reuse of process gases is not included in the flow sheet.

In the direct reduction (DR) process, iron oxides in the ore are reduced to metallic iron in solid state at lower temperatures $\left(900-1000^{\circ} \mathrm{C}\right)$ compared to the $\mathrm{BF}$ process. The reducing agent is coal or a gas comprised mainly of hydrogen and carbon monoxide produced from natural gas. The DRI is charged into an EAF and melted. The carbon content of the liquid iron is reduced by blowing oxygen into the EAF or adding some amount of iron ore. Limestone is also added to remove phosphorus in the iron. To improve efficiency and reduce melting time, additional energy is supplied through oxy-fuel burners fuelled with oil or natural gas. The temperature and composition of the crude steel is then adjusted in ladle metallurgy where e.g. the sulphur content is reduced and different alloys are added. After casting, the steel is formed into finished products in rolling mills. Advantages with 
DRI are that DRI plants have no need for coke ovens and the DRI can be charged directly into an EAF. For small-scale iron production ( $<1$ million tonnes per year) it would be more economically advantageous to invest in DRI production than in a new BF (Ekerot, 2000). Moreover, it is possible to use natural gas which makes it an attractive production route in areas with natural gas reservoirs and cheap natural gas. Instead of charging the DRI into an EAF, the DRI can be charged into a BF to improve productivity or a BOF as cooling agent instead of scrap.

In scrap-based steelmaking, steel is produced from steel scrap. The steel scrap is melted with electricity in an EAF. The principles of the EAF are described in the section about DRI production above. The liquid steel is transferred to ladle metallurgy where the temperature and composition of the crude steel is adjusted to satisfy specified demands. The steel is then cast and transported to rolling mills (Widmark, 2000).

In the production of stainless steel from scrap the main decarburisation process is the argon oxygen decarburisation (AOD) process. Liquid crude steel from the EAF is charged into the AOD converter and oxygen and argon are blown through the steel bath producing steel with very low carbon and sulphide content (Widmark, 2000).

Recycling of steel scrap to produce new steel products is a well-established business. However, the steel consumption is so large that the recycled steel cannot cover more than $30 \%$ of the steel demand in the world (Stålkretsloppet, 2012). To cover the remaining steel demand, steel must be produced from iron ore.

\subsection{Energy use and $\mathrm{CO}_{2}$ emissions in the iron and steel industry}

The iron and steel industry is the second-largest user of energy in the world industrial sector. It accounted for 15\% of the energy distributed to the industrial sector in 2010 (EIA, 2013). In Sweden, the iron and steel industry accounted for $14 \%$ of the industrial energy use and was the second-largest industrial sector regarding energy use (Swedish Energy Agency, 2013b). The energy intensity of steelmaking depends on the production route, type of iron ore and coal used, the steel composition of the steel products, operation control technology and material efficiency (World Steel Association, 2008). In addition, $8 \%$ of the total life cycle energy required to produce the steel is used for mining, preparation and transportation of material. Iron ore-based steel production is more energy intensive than scrap-based steel production due to the chemical energy required to reduce iron ore to iron.

Figure 4 presents energy intensity of steel production in different EU-27 ${ }^{2}$ countries. The average value of energy use of hot rolled products from the BF-BOF route in Europe is 5.8 MWh/tonne, whereas the average energy used in the scrap-EAF route is 1.2 MWh/tonne (European Commission, 2010). The apparently high energy intensity of

\footnotetext{
${ }^{2}$ Belgium (BE), Denmark (DK), France (FR), Germany (DE), Greece (EL), Ireland (IE), Italy (IT), Luxembourg (LU), Netherlands (NL), Portugal (PT), Spain (ES), United Kingdom (UK), Austria (AT), Finland (FI), Sweden (SE), Cyprus (CY), Czech Republic (CZ), Estonia (EE), Hungary (HU), Latvia (LV), Lithuania (LT), Malta (MT), Poland (PL), Slovakia (SK), Slovenia (SI), Bulgaria (BG) and Romania (RO).
} 
Swedish steel production, shown in Figure 4, can be explained by the fact that Sweden has niched its steel production into advanced steel grades, e.g. high-strength steel, which requires higher specific energy use than conventional steel. Moreover, the steel is processed into specialised steel products, which requires high energy use per tonne product. There is an ongoing research project in Sweden, funded by the Swedish Energy Agency, with the aim to define energy indicators that would better reflect the actual energy intensity in the steel industry, taking into account high value-added products.

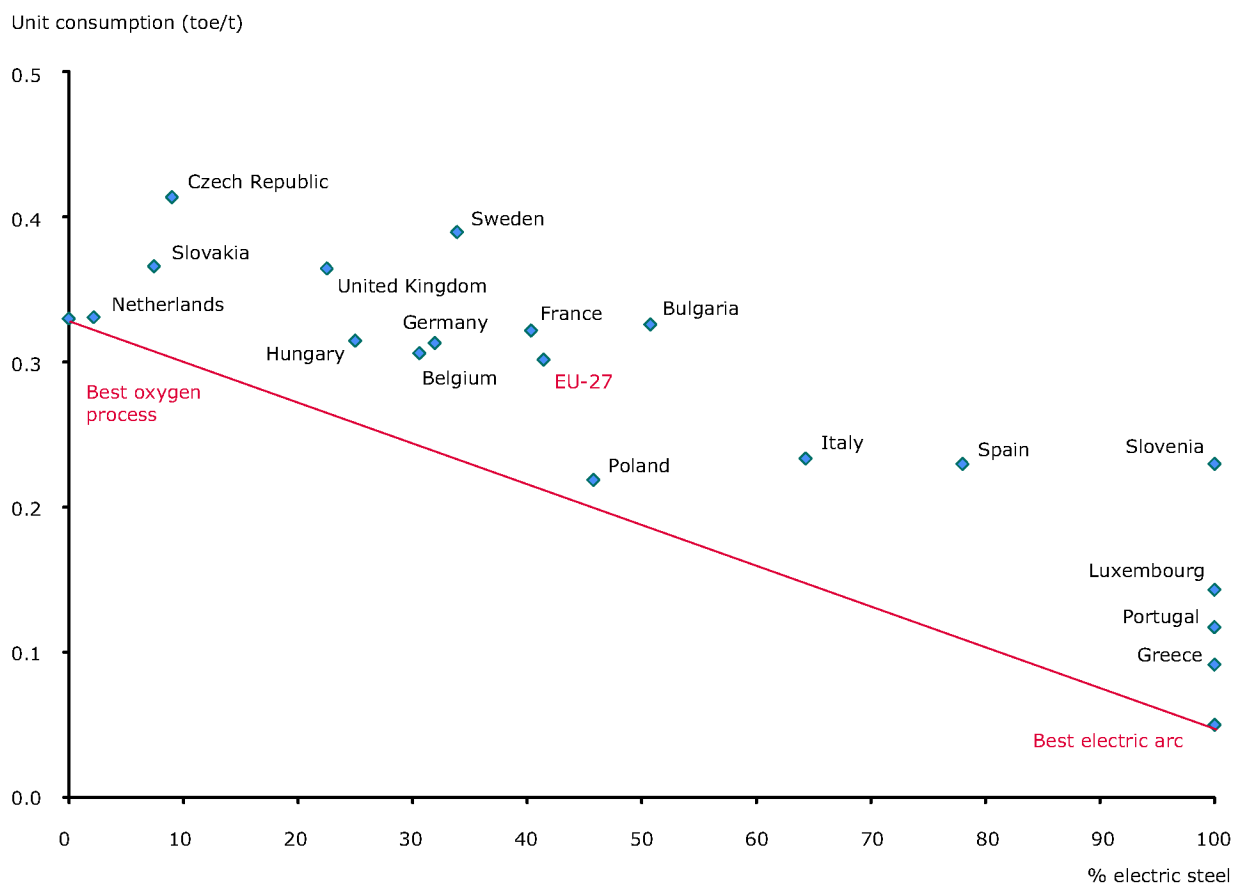

Figure 4. Energy intensity of steel production in different EU-27 countries in 2010, taking into account the relative share of EAF steel production. The red line shows energy intensity of best available technology (BAT). 1 toe=11.63 MWh. Source: European Environment Agency (EEA, 2012)

The iron and steel industry relies to a large extent on fossil fuels and electricity. In 2011, $5 \%$ of the world coal production was consumed in BF (IEA, 2013b). Table 2 shows the main energy inputs to steel production and their applications as energy and reducing agents. By-product gases from coke ovens, BF and BOF can be reused as fuel in furnaces and for electricity and heat production. Typically, these gases contribute about $40 \%$ of total energy use in the iron and steel industry (World Steel Association, 2008). As an example, in Sweden 2007, 4.6 TWh of by-product gases were used internally in steel processes and 2.8 TWh was used for electricity and heat production externally (Jernkontoret, 2013b). This was about 32\% of the total energy used by the iron and steel industry in Sweden in 2007 (Swedish Energy Agency, 2009). A rough description of the 
energy flows in an integrated steel plant ${ }^{3}$ is (Lindeström et al., 2008): 95\% of the energy input is coke and coal to coke ovens and $\mathrm{BF}, 3 \%$ is electricity and the rest is chemical energy in scrap. Approximately 35\% of the energy input in BF-BOF production is bound in the steel slabs, $20 \%$ in energy-rich process gases, $10 \%$ in energy-rich by-products (tar, benzene etc.) and 35\% is heat. The heat constitutes of 30\% cooling water, $25 \%$ hot steel products and slag, 25\% steam and exhaust gases and $20 \%$ unidentified sources. With regard to scrap-based steel production in $\mathrm{EAF}^{4}$, approximately $80 \%$ of the energy input is electricity and the rest is fossil fuels such as oil, LPG and natural gas (Åbyhammar and Östergård, 2001). About 30\% of the energy input in the scrap-based EAF production is found as heat in cooling water, hot materials and exhaust gases. Detailed Sankey diagram of energy flows in an integrated iron and steel mill can be found in Remus et al. (2013).

Table 2. Energy input to the iron and steel industry and its application. Energy carriers generated in production processes e.g. energy-rich process gases are not presented. Source: (World Steel Association, 2008; Jernkontoret, 2013b)

\begin{tabular}{lll} 
Energy source & Application as energy & $\begin{array}{l}\text { Application as energy and } \\
\text { reducing agent }\end{array}$ \\
\hline Coal & - & $\begin{array}{l}\text { Coke production, } \\
\text { pulverised coal injection } \\
\text { into BF, DRI production }\end{array}$ \\
Natural gas & Furnaces & $\begin{array}{l}\text { BF injection, DRI } \\
\text { production }\end{array}$ \\
LPG & Furnaces & - \\
Oil & Furnaces, steam production & BF injection \\
Electricity & EAF, rolling mills, motors, & - \\
\hline
\end{tabular}

During the time period 2007-2011, average $\mathrm{CO}_{2}$ emissions from the iron and steel industry were 1.8 tonnes $\mathrm{CO}_{2}$ /tonne crude steel (World Steel Association, 2012b). Only $\mathrm{CO}_{2}$ emissions were reported since these make up approximately $93 \%$ of the steel industry's GHG emissions (World Steel Association, 2012b). According to Birat (2010) a benchmark integrated steel plant has specific direct fossil $\mathrm{CO}_{2}$ emissions of 1.81 tonnes per tonne of product (hot rolled coils, bars etc.) and when including emissions from electricity production the emissions are 1.84 tonnes of $\mathrm{CO}_{2}$ /tonne product (1.66 $\mathrm{CO}_{2}$ /tonne crude steel). In this case, a European electricity mix generating $370 \mathrm{~g} \mathrm{CO}_{2} / \mathrm{kWh}$ electricity was used. A benchmark steel plant based on the scrap-EAF route has direct specific fossil emissions of 0.10 tonnes of $\mathrm{CO}_{2}$ per tonne of product and if $\mathrm{CO}_{2}$ emissions from electricity production (European mix) are included the emissions are 0.30 tonnes of $\mathrm{CO}_{2} /$ tonne product ( 0.27 tonnes of $\mathrm{CO}_{2} /$ tonne crude steel).

\footnotetext{
${ }^{3}$ Energy use in rolling mills is not included.

${ }^{4}$ Energy use in rolling mills is not included.
} 


\subsection{New technologies for steelmaking}

There are extensive investments in research to find alternative steelmaking processes with less $\mathrm{CO}_{2}$ emissions. ULCOS (Ultra-Low Carbon dioxide Steelmaking) is a European cooperative research and development initiative to find new steelmaking technologies that will enable drastic reduction in $\mathrm{CO}_{2}$ emissions from steel production (Birat et al., 2012; ULCOS, 2013). ULCOS is supported by the European commission and consists of all major EU steel companies, energy and engineering partners, research institutes and universities. The programme is planned to continue at least until 2025. Since the ULCOS programme started in 2004, over 80 technologies have been studied and four breakthrough technologies have been identified to reduce $\mathrm{CO}_{2}$ emissions by at least $50 \%$ compared to best practice of 2004. These technologies are (ULCOS, 2013):

1. Top Gas Recycling Blast Furnace with $\mathrm{CO}_{2}$ Capture and Storage (CCS) Separation of the BF off-gases and recycling of useful components to be used as reducing agent in the $\mathrm{BF}$. Injection of $\mathrm{O}_{2}$ instead of air into the $\mathrm{BF} . \mathrm{CO}_{2}$ in offgases are captured and sent to storage.

2. HIsarna with CCS - Technology based on bath-smelting. Uses pre-heated coal instead of coke. Iron ore is melted and the iron oxides in the melted iron ore are reduced to metallic iron. $\mathrm{CO}_{2}$ in off-gases is captured and sent to storage.

3. ULCORED with CCS - Direct reduction of iron ore with reducing gas produced from natural gas. $\mathrm{CO}_{2}$ in off-gases is captured and sent to storage.

4. Ulcowin and Ulcolysis - Production of iron through electrolysis.

The American Iron and Steel Institute (AISI) is investing in a research and development programme called the AISI $\mathrm{CO}_{2}$ Breakthrough program. This programme is currently funding two projects (AISI, 2013):

1. Molten Oxide Electrolysis (MOE) - Reduction of iron ore through electrolysis.

2. Hydrogen Flash Smelting - Reduction of iron ore in a suspension, with hydrogen as reducing agent.

The Japan Iron and Steel Federation initiated a research programme called $\mathrm{CO}_{2}$ Ultimate Reduction in Steelmaking Process by Innovative Technology for Cool Earth 50 (COURSE 50) with the aim to develop technologies that can reduce $\mathrm{CO}_{2}$ emissions from steelmaking by $30 \%$. New technologies that are investigated in this programme are CCS and reduction of iron ore with hydrogen (JISF, 2011).

The POSCO $\mathrm{CO}_{2}$ Breakthrough Framework programme in Korea aims at developing technologies for reduced $\mathrm{CO}_{2}$ emissions from steel industry. Projects within this programme are: CCS using ammonia and excess heat, $\mathrm{CO}_{2}$ fixation using marine bio-slag, hydrogen production from by-product gases from the steelmaking process, and heat recovery from sintered ore (POSCO, 2013).

The research programmes mentioned above involve several actors and large investments. It is noticeable that a majority of the programmes mentioned rely on the development of the CCS technology. 


\section{Energy efficiency and fuel substitution}

This chapter presents previous studies on energy efficiency potentials, when introducing energy-efficient technology in existing steel plants. The chapter also discusses fuel substitution options and the availability of biomass resources. A short introduction to the subject of industrial excess heat is given and technologies for electricity generation from excess heat are described.

The definition of improved energy efficiency is "reduction in the energy used for a given service (heating, lighting, etc.) or level of activity” (Eichhammer, 2004; World Energy Council, 2008). Therefore, the concept of improved industrial energy efficiency implies that the use of primary energy is reduced and that excess energy is recovered and recycled into the industrial processes or used in other processes. Improved industrial energy efficiency can be accomplished by for example (1) production planning, (2) energyefficient technology, (3) recovery of excess heat, and (4) energy-efficient behaviour or energy conservation.

\subsection{Energy efficiency potential in existing steel plants}

Best available technology (BAT) is defined in the EU Council Directive 96/61/EC (Council of the European Union, 1996) as "the most effective and advanced stage in the development of activities and their methods of operation which indicate the practical suitability of particular techniques for providing in principle the basis for emission limit values designed to prevent and, where that is not practicable, generally to reduce emissions and the impact on the environment as a whole”. BAT for the iron and steel industry has been identified by the European Commission (Remus et al., 2013) and by deploying these technologies, energy savings could be accomplished. The deployment of BAT at all existing steel plants in Europe would result in improved energy efficiency of about $10-15 \%$ in the next $15-20$ years (European Commission, 2010). However, further improvements demand the development of breakthrough innovative technologies, because the BATs used today have already been improved and developed and operate close to their thermodynamic limits (European Commission, 2010). Worrell et al. (2010) completed an energy guide that presents energy efficiency practices and energy-efficient technologies that are available today and could be implemented at iron and steel plants.

There are several recent studies that have investigated energy efficiency potential in the iron and steel industry, see for example (Hasanbeigi et al., 2013; Morrow Iii et al., 2013; Moya and Pardo, 2013; Pardo and Moya, 2013). Hasanbeigi et al. (2013) investigated cost-effective fuel and electricity saving technologies and they concluded that by 
implementing these in the Chinese iron and steel industry, in total 3.3 PWh fuel and 251 TWh electricity could be saved during the time period 2010-2030. Morrow Iii et al. (2013) estimated the total cost-effective energy saving potential for the Indian iron and steel industry at 213 TWh for the same time period. The study by Moya and Pardo (2013) showed that regardless of payback period (1-16 years) the reductions in specific energy use (GJ/tonne crude steel) would be 5\% in EU27 iron and steel industry in 2020 compared to 2010. This moderate decrease was explained by the maturity of the integrated route in Europe. Pardo and Moya (2013) simulated the evolution of the EU27 iron and steel industry up to 2030. They analysed the implementation of BAT and diffusion of innovative technologies, and how the evolution would be affected by increased energy and resource prices and $\mathrm{CO}_{2}$ emissions charges. Their results showed that in the integrated steel production route, BAT has low impact on energy use and $\mathrm{CO}_{2}$ emissions, while innovative technologies could substantially reduce both; up to $12 \%$ decreased specific energy use and $21 \%$ reduction in $\mathrm{CO}_{2}$ emissions. For the scrap-based route, the corresponding specific energy use and $\mathrm{CO}_{2}$ emissions would decrease by $6 \%$ and $11 \%$ respectively in 2030 compared to 2010 .

During 2006-2011, the Swedish steel producers' association (Jernkontoret) organised an energy research programme. The programme was supported by the Swedish Energy Agency. The goal of the research programme was to reduce total energy use, the use of fossil fuels and $\mathrm{CO}_{2}$ emissions (Jernkontoret, 2013a). It was expected that within a tenyear period the programme would result in energy savings of about $4.5-5 \%$ of the Swedish steel industry's total energy demand. There were eight research projects within the programme and they can be summarised as: lowest possible coke consumption in the $\mathrm{BF}$, control and monitoring of slag formation in EAF, energy-efficient refining of pig iron, development of soft-cooled mould for continuous casting of slabs, energy-efficient operation for rolling advanced steel profiles, faster reheating and annealing, furnace control and process analysis, high-temperature biomass gasification and substitution of fossil fuels in the steel industry. The successor of this research programme is a collaboration programme between Jernkontoret and the Swedish Energy Agency called “The iron and steel industry's energy use - research and development". This research programme will run from 2013-2017 and the purpose is to support projects that will increase the steel industry's energy efficiency, to maintain excellence research groups at Swedish universities and research institutes, and to disseminate program results to the industry.

\subsection{Biomass as reducing agent and fuel}

Fuel substitution and reductant substitution in the iron and steel industry would have the potential to significantly reduce $\mathrm{CO}_{2}$ emissions from steel production. As mentioned in Section 2.1, some amounts of coke in the BF can be replaced by injection of auxiliary reductants like pulverised coal. To increase the BF productivity, it is advantageous to have a reducing agent with low ash content; high ash content means that the BF has to be charged with more fluxing agents and hence the slag volume will increase. It is also desired to have a reducing agent with low sulphur content in order to reduce the amount of sulphur which is dissolved in the liquid iron. Biomass has low ash and sulphur content, but high moisture and oxygen content. High moisture content means that energy is needed 
to vaporise the water. Fuels with high oxygen content reduce the flame-temperature in the $\mathrm{BF}$, which limits the amount of biomass that can be fed into the BF without increasing the energy use. Another concern is the heterogeneous structure and low mass density of biomass, which obstructs its feed into the BF.

Several studies have analysed injection of pulverised charcoal into the BF (see e.g. (Helle et al., 2010; Helle et al., 2009; Gupta, 2003; Suopajärvi and Fabritius, 2012; Suopajärvi et al., 2013) . Helle et al. (2010) and Helle et al. (2009) simulated partial substitution of fossil reducing agents with biomass in the BF. They concluded that the biomass had to be pre-processed through pyrolysis, because the high oxygen content and low heating value of raw biomass would reduce the productivity of the BF. Partial pyrolysis of the biomass at $250^{\circ} \mathrm{C}$, prior to injection into the $\mathrm{BF}$, was shown to be the most economical option. Gupta (2003) discussed advantages and limitations with biomass use in iron and steelmaking and predicted future technologies for steelmaking from 2020 to beyond 2041. Advantages discussed were that charcoal is excellent as reducing agent because of low sulphur and ash content, it is a renewable resource, and biomass handling and charcoal production would provide jobs. Reported limitations with biomass use were land management (conflict with agriculture), high moisture content, lower physical strength of charcoal compared to coke, and economy. According to Suopajärvi and Fabritius (2012), injection of pulverised charcoal into BF would reduce direct fossil $\mathrm{CO}_{2}$ emissions by up to $26 \%$ compared to a scenario with heavy oil injection. In this case charcoal production was integrated with iron production and off-gases from the pyrolysis process were used together with BFG and COG to generate electricity. Suopajärvi et al. (2013) reviewed options to replace part of the fossil reducing agents in the BF with different bio-based reducing agents. The bio-reducers evaluated were charcoal, bio-oil, bio-syngas and bioSNG. The review included technological concerns, economy, biomass availability and policy instruments. Results from the study indicated that the most promising bio-based reducing agent in the $\mathrm{BF}$ would be charcoal. The implications of charcoal use were reduced $\mathrm{CO}_{2}$ emissions, better quality of metal, enhanced productivity and decreased slag amounts. Bio-oil produced from wood had high water and oxygen content which made it less suitable as reducing agent in the $\mathrm{BF}$. In order not to reduce the productivity of the $\mathrm{BF}$, auxiliary reducing agents should not be diluted with e.g. nitrogen or $\mathrm{CO}_{2}$. Therefore, bio-syngas as auxiliary reducing agent would require upgrading of the product gas to reach a gas composition of at least 90 vol\% CO and $\mathrm{H}_{2}$ (Suopajärvi et al., 2013). Injection of bio-SNG would be comparable with the injection of natural gas, which is applied at several BF processes worldwide.

There are options to replace fossil reductants in the production of DRI from iron ore. For example, Buergler and Di Donato (2009) investigated integration of biomass gasification with the production of DRI. The bio-syngas was used as reducing agent in the direct reduction process. Requirements were that the bio-syngas should be free of tar, dust, sulphur and nitrogen.

The iron and steel industry is energy-intensive and to convert its energy system from fossil fuels to biofuels would require large volumes of biomass. Substitution of coke with charcoal in the BF has been studied within the ULCOS programme, but the process route was considered unfeasible within a reasonable time horizon; large-scale charcoal 
production would require large land plantations (Birat et al., 2012). It was considered that competition for land between charcoal production, food production and other industrial biomass utilisation would leave the charcoal production with insufficient volumes of biomass. However, Suopajärvi and Fabritius (2013) analysed the biomass availability in Finland and they concluded there would be sufficient amounts of wood energy available, both for current users and for charcoal production to iron and steelmaking in Finland. Several studies have addressed the issue of future primary energy demand and the potential of renewable energy. Moriarty and Honnery (2012) reviewed publications which estimated global technical potential of renewable energy in 2050. The results showed that the estimates for global renewable energy potential in the reviewed studies ranged between 68 and 1,345 PWh, while biomass potential was estimated at 8-417 PWh. Forecasts for estimated primary energy demand in 2050 ranged between 118 and $326 \mathrm{PWh}$. In conclusion, the estimates of technical potential of biomass energy differed greatly between the reviewed publications.

Production of methanol from iron and steel industry by-product gases has been studied (Lundgren et al., 2008; Lundgren et al., 2013; Ghanbari et al., 2011; Ghanbari et al., 2012). Ghanbari et al. (2011) and Ghanbari et al. (2012) studied a polygeneration system comprised of an integrated steel plant with top gas recycling BF and CCS, a combined heat and power (CHP) plant and a methanol plant. Their results showed that the costs of producing liquid steel were reduced when the steel plant was integrated with methanol production and that process integration and increased top gas recycling could reduce $\mathrm{CO}_{2}$ emissions from the system. The latter study also included analysis of injection of auxiliary fuels (biomass, natural gas and oil) into the BF and the results showed best performance for biomass injection. Lundgren et al. (2008) and Lundgren et al. (2013) studied methanol production at an integrated steel plant, where the by-product gases were used together with bio-syngas as feedstock to the methanol production. The production was integrated with the DHS system. The studies showed that the polygeneration system could be economically feasible, and result in reduced energy use and direct emissions of $\mathrm{CO}_{2}$.

\subsection{Recovery of industrial excess heat}

Industrial excess heat is defined in this thesis as heat energy that is generated in an industrial process and wasted to the surroundings without being recovered. Lowtemperature excess heat is defined as heat sources with temperatures below $230^{\circ} \mathrm{C}$ (US Department of Energy, 2008; Crook, 1994).

The excess heat can be differentiated into high-grade heat and low-grade heat. Ammar et al. (2012) defined high-grade heat as heat which is possible to reuse in the industrial processes, while low-grade heat was defined as heat which is not viable to recover within the processes. They presented high-grade heat recovery methods, such as pre-heating feed water or combustion air through heat exchange. They discussed different heat exchangers as well as heat integration based on pinch analysis and total site analysis. Their study also described options for low-grade heat recovery. Some of these options were heating buildings and greenhouses, heat delivery to a DHS, cooling by adsorption and absorption cooling processes, electricity generation and desalinating water. There are several DHS in the world which import industrial excess heat and then distribute the thermal energy to 
customers (Rezaie and Rosen, 2012). Supply temperature in DHS varies in different part of the world. For example, in Sweden the supply temperature varies between $70^{\circ}$ in summer to $120^{\circ} \mathrm{C}$ in winter (Ericsson, 2009).

Bendig et al. (2013) presented a method for identifying, characterising and quantifying industrial excess heat that would be viable to recover. They distinguished between avoidable and unavoidable excess heat and stated that the avoidable excess heat should not be used for external applications, because it could prevent investments in energy efficiency measures. They defined "true" excess heat as "the sum of the exergy that is available in a process after pinch analysis, heat recovery, process integration and energy conversion (hot and cold utility) integration with the help of exergy analysis”. Energy conversion utilities in the study were e.g. gas boilers, cooling water and heat pumps. The definition may guide engineers in quantifying the potential for excess heat recovery for external use without using avoidable excess heat. However, in this thesis no distinction between avoidable and unavoidable excess heat has been made.

In another study, Law et al. (2013) reviewed BAT for recovery of industrial excess heat and they concluded that the most economical option would be heat exchange in the industrial process or with nearby processes. Other options such as electricity generation, cooling through absorption chillers and heat pumps were found to be less economical.

Villar et al. (2012) analysed technologies for excess energy recovery in continuous process industries, with the focus on the iron and steel industry. Options for excess heat recovery presented were: excess heat to DHS, coke dry quenching (CDQ) to recover heat for on-site use or electricity generation, recuperation system in the $\mathrm{BF}$, regenerative burners in furnaces, exhaust gas cooling system with steam recovery boiler, and scrap preheating.

A case study at a Chinese integrated steel plant was performed by Zhang et al. (2013a) and they estimated excess heat recovery potential at $26 \%$ of the steel plant's total energy use. They suggested for example utilisation as $\mathrm{DH}$ and heat-driven electricity production. Slag is a large source of excess energy in the iron and steel industry. The slag is tapped at temperatures of up to $1650^{\circ} \mathrm{C}$ and the heat energy is generally not recovered (Barati et al., 2011). Energy recovery from high-temperature slag in the iron and steel industry has been studied by e.g. Barati et al. (2011); Zhang et al. (2013b). Options analysed were recovery as thermal energy (steam and hot air), utilisation of the heat in endothermic chemical reactions to produce $\mathrm{CO}$ and $\mathrm{H}_{2}$ from coal and methane (gasification and methane reforming), and production of electricity. Slag has low thermal conductivity and to achieve efficient heat recovery the slag must be granulated to increase the surface area. Gutiérrez Trashorras et al. (2013) designed a heat recuperator for heat recovery from molten slag and calculated its performance. They concluded that the recuperator could have an efficiency of about $92 \%$.

\subsection{Electricity production from excess heat}

There are different technologies that can be used to produce electricity from industrial excess heat (Goswami and Kreith, 2007). Power cycles convert heat energy into mechanical energy and then the mechanical energy is converted into electricity. Examples 
of power cycles are Stirling cycle, Rankine cycle, organic Rankine cycle (ORC), Kalina cycle and phase change material (PCM) engine.

The Stirling cycle features a closed system in which a working gas (air, helium or hydrogen) is alternatively heated and cooled when moving between different temperatures locations in the engine (Goswami and Kreith, 2007; Keveney, 2013). There are different configurations of the Stirling engine and the main forms are alpha, beta, gamma and double-acting Stirling engines (Electropaedia, 2014). In a two-cylinder Stirling engine (alpha configuration), one cylinder is kept hot and the other is kept cold and the working gas contracts at the cold cylinder and expands at the hot cylinder resulting in a movement of the gas. The transfer of working gas between the hot and cold cylinders makes the pistons in the cylinders move. The kinetic energy is converted to electricity in a generator. The working principle of a two-cylinder Stirling engine is shown in Figure 5.

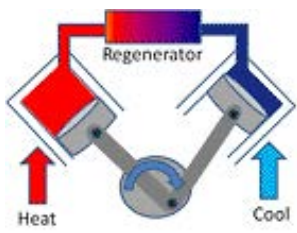

(2)

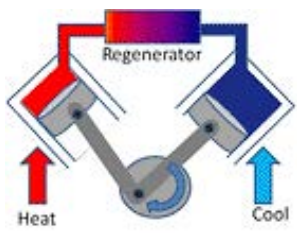

(3)

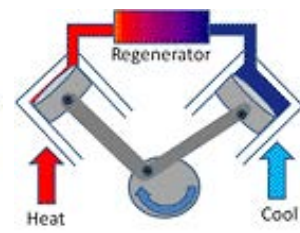

(4)

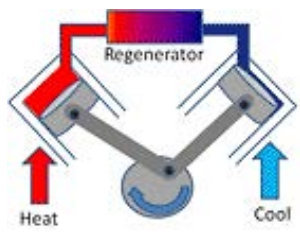

Figure 5. A schematic picture of the working principle of a two-cylinder Stirling engine. A working gas, e.g. air, is enclosed within two cylinders. One cylinder is kept hot and the other cold and the working gas moves between these two. (1) The working gas in the hot cylinder is heated and expands, pushing the piston down. This causes the crank shaft to move, generating mechanical energy. (2) A momentum of a flywheel on the crank shaft pushes the piston in the hot cylinder up and the gas is forced into the cold cylinder pushing the piston in the cold cylinder down. (3) The gas in the cold cylinder contracts as its temperature drops. This causes the piston to rise and the momentum of the flywheel forces the gas back to the hot cylinder.

(4) The gas is heated again and expands, pushing the piston in the hot cylinder down and the cycle starts again. The regenerator between the two cylinders is not necessary but improves the efficiency of the engine. Reprinted with permission from

Electropaedia (2014).

The Rankine cycle, the ORC and the Kalina cycle have the same energy conversion mechanism, but use different working media; the Rankine cycle uses water, the ORC uses an organic liquid with lower boiling point than water, and the Kalina cycle uses a mixture of ammonia and water. The working medium circulates in a closed loop and one power cycle can be described as (Goswami and Kreith, 2007): (1) the working medium is pressurised and pumped into a boiler where it is heated and vaporised; (2) the gaseous working medium expands in a turbine; (3) the mechanical energy is converted into electricity in a generator; (4) the working medium is cooled into liquid form in a condenser; and (5) the working medium is pumped back to the boiler. Figure 6 presents the working principles of an ORC. 


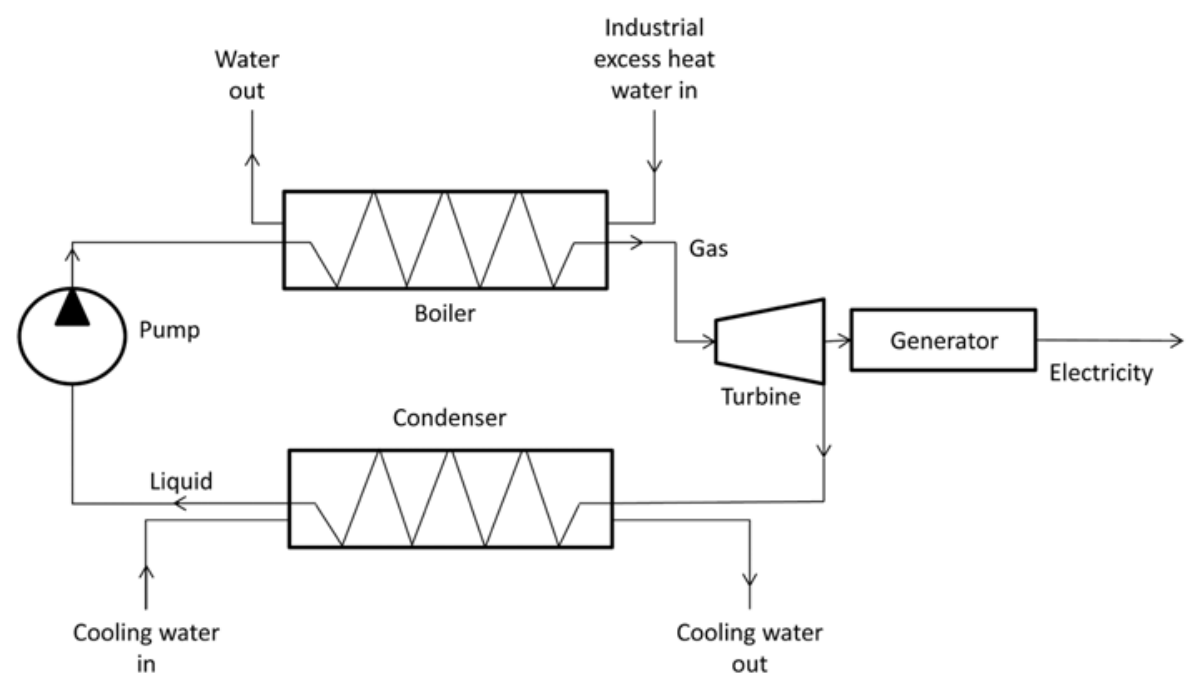

Figure 6. A schematic picture of the organic Rankine cycle. The organic working medium circulates in a closed loop. In a power cycle, the fluid is pumped to a boiler where it is heated to above boiling point under pressure. The gaseous working medium is then expanded in a turbine and the mechanical energy is converted into electricity in a generator. The working medium is cooled in a condenser and the fluid is again pumped into the boiler.

The PCM engine uses a paraffin mixture as working medium and its power cycle can be described as: (1) the solid paraffin is heated into liquid form in an energy cell and expands under high pressure; (2) the liquid paraffin is cooled into solid form and contracts; (3) the mechanical energy in the form of volume expansions and contractions are captured in a hydraulic system; and (4) the mechanical energy is converted into electricity in a generator. The technology requires cooling water to operate. A schematic picture of the PCM engine system is presented in Figure 7.

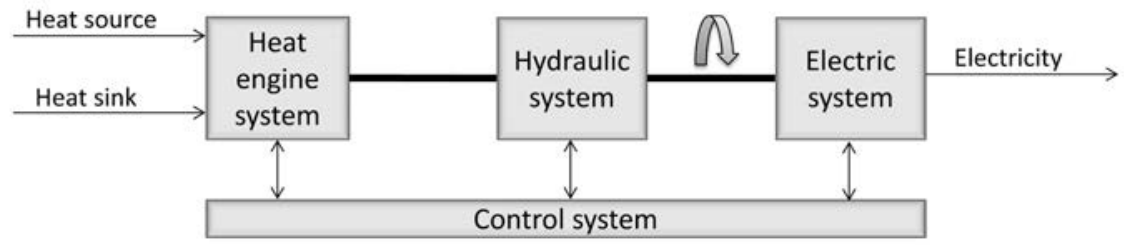

Figure 7. In the energy cell in the heat engine system, heat is absorbed by a paraffin mixture which changes from solid to liquid phase under high pressure. This results in a volume expansion. The liquid paraffin is then cooled and changes back to solid state and the volume is reduced. The work of volume expansion and contraction is captured in a hydraulic system and the mechanical energy is then converted into electricity in a generator. 
There are also solid state energy converters. TEG is a solid state energy converter that uses the Seebeck effect to generate electricity (Rowe, 1995; Minea, 2012). A TEG is comprised of a cooling system with air or water and one or more thermoelectric modules. The modules are comprised of a large number of thermocouples connected electrically in series and thermally in parallel. A thermocouple consists of two semiconductors with different Seebeck coefficients ${ }^{5}$. When one side of the thermocouple is heated and the other side is cooled, electrical power is generated because electrons at the hot end become more energetic and start to move towards the cold end. The optimal TE material is a good electrical conductor and a poor thermal conductor. Figure 8 shows the working principle of electricity generation in a semiconductor thermocouple.

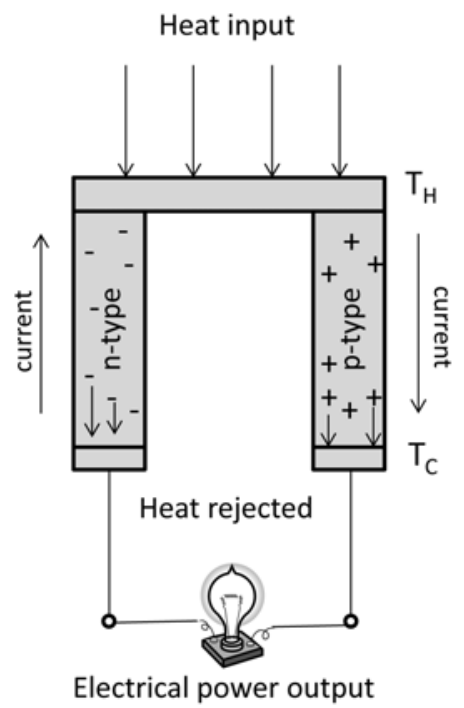

Figure 8. A semiconductor thermocouple. Heat energy causes the charge carriers (electrons in the n-type material and holes in the p-type material) at the hot end $\left(\mathrm{T}_{\mathrm{H}}\right)$ to be transferred to the conduction band. The charge carriers start to repel each other and move towards the cold end $\left(\mathrm{T}_{\mathrm{C}}\right)$, which produces a current flowing from the cold side to the hot side in the n-type material and from the hot side to the cold side in the p-type material. By connecting the two junctions, a current will flow in an external circuit. Several thermocouples can be connected forming a module.

Another solid state energy converter is thermophotovoltaic (TPV) (Chubb, 2007). This technology produces electricity from heat radiation emitted from a high-temperature material $\left(1000-1800^{\circ} \mathrm{C}\right.$ ) (Bauer et al., 2004). The photovoltaic (PV) cell is made of a semiconductor material. Photons can excite electrons from the valence to the conduction band in the PV cell, thus producing electricity. The gap between the valence band and the conduction band is called the band gap. In order to excite electrons to the conduction 5 The Seebeck coefficient is the thermoelectric potential difference developed per unit
temperature difference in the material. 
band, the photons must have higher energy than the band gap energy. A TPV generator consists of a heat source, an emitter, a filter and an array of PV cells (Ferrari et al., 2014). In addition, there is a cooling system which prevents the PV cells from being overheated, which would reduce the efficiency of the TPV generator. The cooling water (or air) could be used as heat source in other heat recovery options. A schematic picture of a TPV generator is shown in Figure 9.

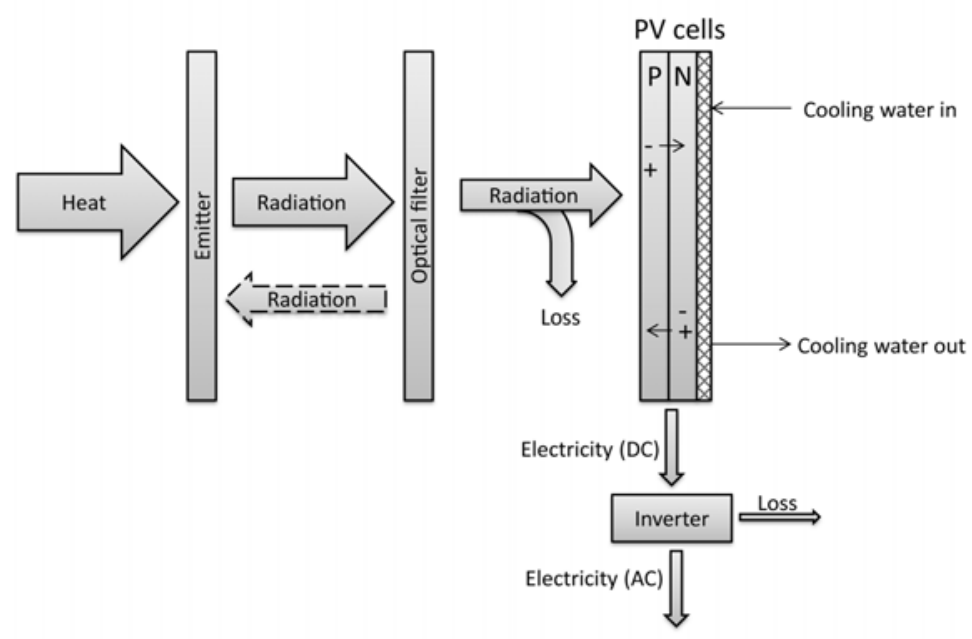

Figure 9. The principles of a thermophotovoltaic generator. The hot surface, the emitter, sends out radiation energy which is filtered in an optical filter. The optical filter selectively lets photons with energy higher than the PV cell band gap pass through and blocks photons with energy lower than the PV cell band gap. In the PV cell, the photons excite electrons to the conduction band, generating a current. An inverter transforms the DC current into AC current. Heat energy generated by the PV cell is absorbed by cooling water which can be used for other applications, e.g. DH, ORC or TEG. (Adapted from (Ferrari et al., 2014)) 


\section{Biomass gasification}

This chapter gives an introduction to biomass gasification and describes the different steps in the production process from biomass feedstock to final product. An overview of European biomass gasification projects and some recent research about integration of biomass gasification in industry are presented.

Gasification is thermochemical conversion of carbonaceous material into an energy-rich gaseous fuel. The cleaned and upgraded product gas is called syngas or synthesis gas. Gasification and combustion are closely related, but in the gasification process the oxygen supply is reduced, resulting in a partial combustion of the feedstock. Syngas produced through gasification of biomass consists of carbon monoxide (CO) and hydrogen gas $\left(\mathrm{H}_{2}\right)$, with smaller amounts of $\mathrm{CO}_{2}$, methane $\left(\mathrm{CH}_{4}\right)$, heavier hydrocarbons and steam. Gasification of fossil feedstock is a well-established technology that has been used commercially for decades, but biomass gasification for advanced applications is still at the development stage.

There are a number of reasons for the increased interest in the development of the biomass gasification technology (Spellman, 2011):

- A gaseous fuel is more flexible than a solid fuel as it can be used in many applications, e.g. boilers, turbines, engines, fuel cells. It can also be blended with other gaseous fuels like natural gas.

- Gasification can produce a clean fuel and remove contaminants found in the biomass.

- Gasification can handle a wide range of biomass feedstock without any major changes in the process.

- Waste fuels containing hazardous compounds and heavy metals can be gasified and the hazards can be safely removed.

Some of the disadvantages with biomass gasification are the high investment cost and the large building area required for reactors and biomass handling. Other concerns are that biomass is inhomogeneous material and fuel size, moisture content etc. have to be controlled to fulfil requirements for the specific gasifier. This heterogeneity of the biomass feedstock may also result in that chemical and physical properties of the product gas, such as energy density, gas composition and impurities, vary over time. 
Thermochemical conversion of biomass into syngas principally includes four steps: 1) pre-treatment of biomass; 2) gasification; 3) gas-cleaning; and 4) gas upgrading. The bio-syngas can be used as fuel for electricity and heat production, but can also be converted into a number of products such as Fischer Tropsch (FT) diesel, SNG, methanol, ethanol, dimethyl ether (DME) and ammonia. This thesis studies a gasification system with production of bio-SNG and therefore a description of the conversion of syngas into SNG (methanation) is presented. Bio-SNG is bio-methane produced from bio-syngas and should not be confused with biogas produced through anaerobic digestion of biomass.

\subsection{Pre-treatment}

Biomass is a heterogeneous material and the group includes both solids and liquids. Sources of biomass are virgin terrestrial and aquatic biomass but also organic waste such as forest residues and agricultural, municipal and industrial wastes. The performance of the gasification process is influenced by physical and thermodynamic properties of the biomass. For example, uneven structure and high moisture content cause difficulties in maintaining constant feed rates into the gasifier and high moisture content requires large amounts of heat for vaporization. This will reduce the amount of energy delivered from the gasifier. Therefore biomass is often pre-treated before gasification. The pre-treatment step can include removal of foreign materials (e.g. rocks and metal), drying to reduce the moisture content, and size reduction (e.g. chipping, grinding and pulverization) (Basu, 2010). There are also thermal pre-treatment methods which increase the energy density of biomass e.g. torrefaction (slow pyrolysis) and fast pyrolysis (van der Stelt et al., 2011; Engvall et al., 2011; Bridgwater, 2012). Torrefaction is performed at $200-300^{\circ} \mathrm{C}$ and degrades the fibrous structure of biomass, reduces oxygen content and increases energy density. In fast pyrolysis, the biomass is converted into bio-oils and char at $500^{\circ} \mathrm{C}$. Torrefied and pyrolysed biomass can be ground to powder (or slurry if the char from pyrolysis is ground together with the bio-oil) suitable as feedstock to entrained flow gasification.

\subsection{Gasification}

In the gasification process, air, steam and/or oxygen are used as gasifying agent and syngas is produced when the gasifying agent reacts with solid carbon and hydrocarbons in the biomass. The choice of gasifying agent affects the heating value of the product gas. Air as gasifying agent results in a product gas with a heating value of $1-2 \mathrm{kWh} / \mathrm{Nm}^{3}$ (4-7 MJ/Nm${ }^{3}$, while steam and oxygen generate a syngas with a heating value of 3-5 $\mathrm{kWh} / \mathrm{Nm}^{3}\left(10-18 \mathrm{MJ} / \mathrm{Nm}^{3}\right)$ and 3-8 $\mathrm{kWh} / \mathrm{Nm}^{3}\left(12-28 \mathrm{MJ} / \mathrm{Nm}^{3}\right)$ respectively (Basu, 2010). There are different types of gasifiers and they can be directly or indirectly heated, and work at atmospheric or pressurised conditions. Low-temperature gasification is carried out at temperatures below $1,000^{\circ} \mathrm{C}$ and high-temperature gasification is carried out at temperatures above $1,200^{\circ} \mathrm{C}$. In low-temperature gasification, heavier hydrocarbons are produced together with $\mathrm{CO}$ and $\mathrm{H}_{2}$, while high-temperature gasification mainly produces $\mathrm{CO}$ and $\mathrm{H}_{2}$. 
There are three main gasification technologies (Basu, 2010; Spellman, 2011; Knoef and Ahrenfeldt, 2005):

- $\quad$ Fixed-bed/Moving-bed reactor, e.g., Updraft, Downdraft, Crossdraft - fuel particles are supported on a grate, reaction zone temperature is $1090^{\circ} \mathrm{C}$, feed size $<51 \mathrm{~mm}$, small capacities $10 \mathrm{~kW}_{\mathrm{th}}-10 \mathrm{MW}_{\text {th }}$, suitable for biomass gasification

- $\quad$ Fluidized bed reactor, e.g., Bubbling, Circulating, Twin bed - fuel particles are conveyed through the reactor by the gasifying agent, reaction zone temperature is typically $800-1000^{\circ} \mathrm{C}$, feed size $<6 \mathrm{~mm}$, medium-size capacities $5 \mathrm{MW}_{\text {th- }}$ $100 \mathrm{MW}_{\text {th }}$, can operate with a wide range of fuels and is excellent for biomass gasification

- Entrained-flow reactor, e.g., Coaxial downflow, Opposed jet - fuel particles are conveyed through the reactor by the gasifying agent, reaction zone temperature is $1990^{\circ} \mathrm{C}$, feed size $<0.15 \mathrm{~mm}$, large capacities $>50 \mathrm{MW}_{\text {th }}$, not suitable for biomass gasification without pre-treatment such as pyrolysis due to requirement for fine structured feedstock.

Fixed-bed gasifiers are normally simpler and less expensive and produce a syngas with a lower heating value. Fluidized-bed gasifiers and entrained-flow gasifiers are more complex and more expensive and produce a syngas with a higher heating value (Spellman, 2011). To date, the installed technologies for biomass gasification into biofuels (presented in Table 3) split equally between fluidized bed gasifiers and entrained-flow gasifiers (Bacovsky et al., 2013).

\subsection{Gas cleaning}

The produced bio-syngas contains impurities including particulates, tars, sulphur compounds, nitrogen compounds and alkali compounds. There are different gas cleaning systems and which to use depends on the downstream application of the bio-syngas (Basu, 2010; Laudal Iversen and Gøbel, 2005; Rezaiyan and Cheremisinoff, 2005; Spellman, 2011). A simple gas cleaning technique for removal of particulates is a cyclone. Different types of mechanical filters can also be used to remove particulates. If the purpose is to use the bio-syngas as feedstock for synthesis of chemicals or transportation fuel, a more thorough cleaning of the gas has to be performed. Wet scrubber with condensation removes tars and water and one recently developed method is OLGA which uses oil as a scrubbing medium (Engvall et al., 2011). Alkali compounds can be removed with wet scrubbing or by cooling the gas below condensation temperature and removing the alkali particles with barrier filters. Methods for removal of chlorine and sulphur compounds are physical and chemical washing methods such as the Rectisol process and the Selexol process. These processes also remove $\mathrm{CO}_{2}$. Hot gas cleaning such as catalytic cracking can be used to remove tars and ammonia. 


\subsection{Gas upgrading}

In the gas upgrading step, the main gas composition of the bio-syngas is adjusted to meet demands of subsequent gas applications (Basu, 2010; Boerrigter and Rauch, 2005). The main processes in gas upgrading are adjustment of the $\mathrm{H}_{2} / \mathrm{CO}$ ratio and $\mathrm{CO}_{2}$ removal. To increase the $\mathrm{H}_{2} / \mathrm{CO}$ ratio, the water-gas shift reaction is used and $\mathrm{CO}_{2}$ can be removed by chemical and physical absorption, e.g. Pressure Swing Adsorption (PSA) and Selexol (Engvall et al., 2011).

\subsection{Methanation}

Production of $\mathrm{CH}_{4}$ from bio-syngas involves a methanation step. In the methanation reaction, $\mathrm{CO}$ and $\mathrm{CO}_{2}$ react with $\mathrm{H}_{2}$ and produces $\mathrm{CH}_{4}$ and water (Basu, 2010; Bacovsky et al., 2010). The reaction is highly exothermic and heat has to be removed in order to achieve a high reaction rate. Moreover, the catalyst used in the methanation reaction is sensitive to sulphur and chlorine which means that the bio-syngas has to be cleaned from these elements before methanation (Engvall et al., 2011). The produced raw bio-SNG is cleaned and upgraded. The upgrading step includes removal of $\mathrm{CO}_{2}$ and drying to remove water.

\subsection{Biomass gasification projects}

There are commercial facilities that produce bio-syngas for CHP production, but there is no commercial production of second-generation liquid biofuels through gasification in Europe (Bacovsky et al., 2013; Janssen et al., 2013). Table 3 presents an overview of liquid biofuel production plants in Europe. Due to economic reasons, several initiatives have been abandoned in recent years (Janssen et al., 2013).

Table 3. Biomass gasification plants for synthetic liquid fuels in Europe. Source (Bacovsky et al., 2013; Held, 2012; Hellsmark, 2010; Janssen et al., 2013; Johansson, 2013)

\begin{tabular}{|c|c|c|c|c|c|}
\hline Company & Location & $\begin{array}{l}\text { Size } \\
\text { (biomass } \\
\text { input) } \\
\end{array}$ & Development phase & Product & $\begin{array}{l}\text { Start- } \\
\text { up } \\
\text { year } \\
\end{array}$ \\
\hline $\begin{array}{l}\text { Biomasse- } \\
\text { kraftwerk and }\end{array}$ & $\begin{array}{l}\text { Güssing, } \\
\text { Austria }\end{array}$ & $8 \mathrm{MW}$ & Operational demo & CHP & 2002 \\
\hline Vienna & & & & SNG & 2008 \\
\hline $\begin{array}{l}\text { University of } \\
\text { Technology }\end{array}$ & & & & FT diesel & 2009 \\
\hline $\begin{array}{l}\text { Chalmers } \\
\text { University of } \\
\text { Technology }\end{array}$ & $\begin{array}{l}\text { Gothenburg, } \\
\text { Sweden }\end{array}$ & $6 \mathrm{MW}$ & Operational pilot & SNG & 2007 \\
\hline ECN & $\begin{array}{l}\text { Petten, } \\
\text { Netherlands }\end{array}$ & $0.8 \mathrm{MW}$ & Operational pilot & SNG & 2008 \\
\hline Chemrec/ LTU & Piteå, Sweden & $3 \mathrm{MW}$ & Operational pilot & DME & 2011 \\
\hline
\end{tabular}




\begin{tabular}{|c|c|c|c|c|c|}
\hline Company & Location & $\begin{array}{l}\text { Size } \\
\text { (biomass } \\
\text { input) } \\
\end{array}$ & Development phase & Product & $\begin{array}{l}\text { Start- } \\
\text { up } \\
\text { year } \\
\end{array}$ \\
\hline Göteborg Energi & $\begin{array}{l}\text { Gothenburg, } \\
\text { Sweden }\end{array}$ & $32 \mathrm{MW}$ & Operational demo & SNG & 2013 \\
\hline $\begin{array}{l}\text { Karlsruhe Institute } \\
\text { of Technology }\end{array}$ & $\begin{array}{l}\text { Karlsruhe, } \\
\text { Germany }\end{array}$ & $5 \mathrm{MW}$ & $\begin{array}{l}\text { Pilot, under } \\
\text { construction }\end{array}$ & DME & 2013 \\
\hline TUBITAK & Gebze, Turkey & & $\begin{array}{l}\text { Pilot under } \\
\text { construction }\end{array}$ & FT diesel & 2013 \\
\hline ECN & $\begin{array}{l}\text { Alkmaar, } \\
\text { Netherlands }\end{array}$ & $12 \mathrm{MW}$ & Planned demo & SNG & 2014 \\
\hline $\begin{array}{l}\text { NSE Biofuels Oy, } \\
\text { Neste and Stora } \\
\text { Enso }\end{array}$ & $\begin{array}{l}\text { Varkaus, } \\
\text { Finland }\end{array}$ & $12 \mathrm{MW}$ & $\begin{array}{l}\text { Pilot, stopped after } \\
\text { successful trials }\end{array}$ & FT diesel & 2009 \\
\hline $\begin{array}{l}\text { CHOREN Fuel } \\
\text { Freiberg GmbH \& } \\
\text { Co KG }\end{array}$ & $\begin{array}{l}\text { Freiberg, } \\
\text { Germany }\end{array}$ & $45 \mathrm{MW}$ & $\begin{array}{l}\text { Demo, under } \\
\text { commissioning, } \\
\text { company closed }\end{array}$ & FT diesel & 2012 \\
\hline E.ON & $\begin{array}{l}\text { Landskrona or } \\
\text { Malmö, } \\
\text { Sweden }\end{array}$ & $200 \mathrm{MW}$ & $\begin{array}{l}\text { Semi-commercial, } \\
\text { plans put on hold }\end{array}$ & SNG & \\
\hline $\begin{array}{l}\text { CHOREN } \\
\text { Industries GmbH }\end{array}$ & $\begin{array}{l}\text { Schwedt, } \\
\text { Germany }\end{array}$ & $640 \mathrm{MW}$ & $\begin{array}{l}\text { Planned commercial } \\
\text { plant, company } \\
\text { closed }\end{array}$ & FT diesel & \\
\hline Chemrec & $\begin{array}{l}\text { Örnsköldsvik, } \\
\text { Sweden }\end{array}$ & $150 \mathrm{MW}$ & $\begin{array}{l}\text { Demo, plans put on } \\
\text { hold }\end{array}$ & DME & \\
\hline
\end{tabular}

\subsection{Integration of biomass gasification with industry}

Integration of biomass gasification with other processes could increase profitability and improve the overall energy system efficiency. This has been investigated in previous studies.

Hydrogen production for the oil refinery industry through biomass gasification has been studied, see for example (Johansson et al., 2012; Brau et al., 2013; Brau et al., 2012). These studies showed that integration of the gasifier with the oil refinery would result in increased energy efficiency, e.g. excess heat from the refinery could be used to dry biomass to the gasifier, while excess heat from the gasifier could be used to produce steam to the refinery. 
Arvidsson et al. (2012) studied integration of bio-SNG production with a chemical industry currently using natural gas as feedstock. Results showed that excess heat from the gasifier could be used to produce steam that would cover the steam demand at the chemical plant or to produce electricity for the bio-SNG production.

Integration of biomass gasification with pulp and paper industry has been analysed by several authors, see for example (Ljungstedt et al., 2013; Isaksson et al., 2012a; Isaksson et al., 2012b; Wetterlund et al., 2011). Ljungstedt et al. (2013) concluded that integration of biomass-based FT diesel production with a pulp and paper mill would result in higher energy efficiency and lower production cost compared to stand-alone operation. Colocation was shown to reduce global $\mathrm{CO}_{2}$ emissions if the electricity used in the processes was produced in natural gas combined cycle (NGCC) plants or with a technology emitting less than a NGCC plant. Isaksson et al. (2012b) analysed integration of biomass gasification for production of electricity, methanol or FT diesel with a thermo-mechanical pulp mill. Their results showed that excess heat from the gasifier could be used by the pulp mill. Both stand-alone operations and integrated operations were shown to reduce global $\mathrm{CO}_{2}$ emissions. Wetterlund et al. (2011) showed that integration of biomass gasification for production of transportation biofuels or electricity could be profitable for the pulp and paper mill. The impact on global $\mathrm{CO}_{2}$ emissions depended on alternative biomass use and marginal electricity generation technology.

There are a number of studies on biomass gasification in the iron and steel industry. Some of these studies are presented in Section 3.2. 


\section{Assessment of $\mathrm{CO}_{2}$ emissions}

This chapter describes different approaches for valuating $\mathrm{CO}_{2}$ consequences of new investments and changes in energy systems.

When evaluating how changes in energy systems, such as energy efficiency measures or fuel substitution, affect global $\mathrm{CO}_{2}$ emissions, the results may be very different depending on the method and system boundaries chosen. The $\mathrm{CO}_{2}$ consequences of fossil fuel utilisation are rather straightforward, but the $\mathrm{CO}_{2}$ emissions from utilising electricity and biomass are more difficult to estimate.

\section{$5.1 \mathrm{CO}_{2}$ assessment of electricity use}

There are different approaches for valuating electricity production and electricity use. One method for $\mathrm{CO}_{2}$ assessment of electricity production is the average electricity production method (Dotzauer, 2010). In this method, $\mathrm{CO}_{2}$ emissions are calculated for the average mix of fuels used in electricity production in the geographical area studied. The area could for example be a country and the average mix of fuels would be calculated from statistics of electricity production in that country. The results would of course differ significantly depending on which geographical area the calculations are based on.

However, when studying changes in electricity production and electricity use, the average electricity approach would not reflect the real consequences. In this case the marginal electricity method would be a better choice. According to the marginal electricity principle, changes in electricity use would affect the electricity production with the highest operational costs at a given time (Dotzauer, 2010). This is referred to as operating-margin electricity and increased or decreased electricity use in the system would result in increased or decreased production of marginal electricity. In a European perspective, it is commonly assumed that coal condensing power (CCP) plants are operating marginal electricity producers.

When studying changes in energy systems in longer time perspectives, base load buildmargin electricity rather than operating margin should be considered. The base load build-margin is the electricity production facility that will be built when a new generation capacity is installed (Broekhoff et al., 2007). To predict future base load build-margin electricity production is challenging. Therefore, in studies with longer time perspectives, scenario analysis could be used to evaluate different possible future energy markets (Dotzauer, 2010; Axelsson and Harvey, 2010). In the time frame of 2030, it is assumed that a likely base load build-margin technology for electricity production could be CCP 
plants or natural gas combined cycles (NGCC) (Sköldberg and Unger, 2008; Sköldberg et al., 2006).

\section{$5.2 \mathrm{CO}_{2}$ assessment of biomass use}

Biomass is the biodegradable fraction of products, waste and residues from agriculture (including vegetal and animal substances), forestry and related industries, as well as the biodegradable fraction of industrial and municipal waste (European Parliament, 2001). In a short time perspective, biomass use could be seen as $\mathrm{CO}_{2}$ neutral as long as harvesting is accompanied by replanting. However, as a result of policy measures for increasing the share of renewable resources in the energy system, the demand for biomass would increase (Kautto et al., 2012). Biomass is a limited resource and there would be both local and international competition for the resource in the future. Therefore analysis of future changes in biomass use should include alternative use of biomass. When the demand for biomass is increased in a process, there would be less biomass available for other users. The user that would use less biomass as a result of this competition is the marginal (pricesetting) biomass user. The biomass market of today consists of several local heterogeneous markets with diversified pricing, but there would probably be a European market in the future (Axelsson and Harvey, 2010). It is not easy to identify the marginal user of wood fuel, but there are two potential alternatives: (1) CCP plants with the capability of co-firing some wood fuel with the coal and (2) producers of transportation fuels (Axelsson and Harvey, 2010). These user categories are high volume users of biomass with a high willingness to pay. The wood fuel demand of these plants would be larger than the supply and hence they would be likely marginal users. The biofuels produced for the transport sector could for example be FT diesel, DME or ethanol. The marginal perspective on biomass implies that increased biomass use in a process would lead to more fossil coal or fossil transportation fuel being used. The increase in $\mathrm{CO}_{2}$ emissions originated from this additional use of fossil fuel should hence be allocated to the user of biomass. 


\section{Energy management in industry}

This chapter presents theory about energy management and energy management systems. Barriers that prevent improved energy efficiency in industry and driving forces that promote increased energy efficiency are also presented. The chapter ends with an overview of energy-related European policy instruments that affect the European iron and steel industry.

\subsection{Energy management}

Miles (2012) described management as the process of achieving an organisation's mission, strategies, goals, and objectives through the use of human, financial, physical, and informational resources. Energy management is the practice by which a company works strategically with energy issues, and an energy management system is a tool to be used by the company in order to implement energy management (Thollander and Palm, 2013). International energy experts have developed an international energy management standard, ISO 50001, which outlines best practices for energy management. ISO 50001 follows the Plan-Do-Check-Act (PDCA) process for continuous improvements, which was promoted by Deming (2000). Figure 10 illustrates the process of continuous improvements of energy management following the PDCA cycle.

The process of continuous improvement has its starting point in the company's energy policy. In the energy planning phase, an energy audit is performed and targets and action plans, which meet legal requirements and the company's energy policy, are set. The next step is implementation and operation of the action plan. This involves for example procurement, operational control, communication, documentation, and training of employees. The company's energy performance and energy management are then checked and verified. This involves actions such as energy monitoring and energy performance analysis, reporting of results, evaluation of compliance with legal requirements and the company's energy policy, and corrective and preventive actions. The management then performs a review where opportunities to improve energy performance are identified and the company's energy policy and targets are revised. The review ensures continual improvements in energy performance and the energy management system. 


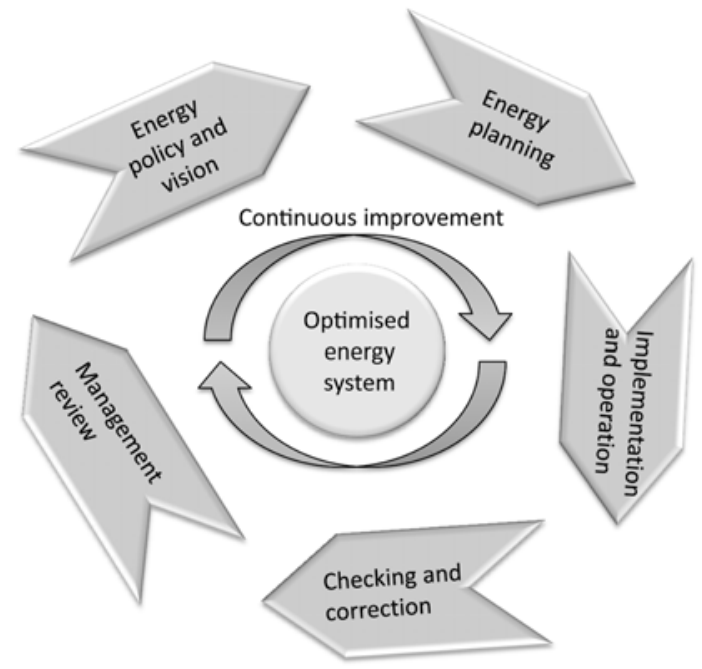

Figure 10. A cycle for continuous improvement of energy management and energy efficiency based on the Plan-Do-Check-Act approach (inspired by Deming (2000), International Organization for Standardization (2011), and the US Department of Energy - Advanced Manufacturing Office (2013)).

Caffall (1995) stated that successful energy management requires a strategic approach and he identified factors that are important for successful energy management:

1. an initial energy audit

2. senior management support

3. monitoring of energy use

4. recognition that management is as important as technology

5. an organised and ongoing programme of energy-saving projects

It has been shown that companies that practiced strategic energy management reduced their total energy use by up to $40 \%$ (Caffall, 1995). A key factor for accomplishing improvements in industrial energy efficiency is a long-term energy strategy (Apeaning and Thollander, 2013; Hasanbeigi et al., 2010; Rohdin et al., 2007; Thollander and Ottosson, 2008; Thollander et al., 2013) and an energy management system could be a tool, when establishing and maintaining such a strategy.

Thollander and Palm (2013) analysed and discussed improved energy efficiency and energy management in industry. Their interdisciplinary analysis integrated technical, economic, and behavioural aspects. They concluded, for example, that engaging and empowering individuals in an organisation to work with improving energy efficiency is a key factor for the establishment of an organisational culture of energy efficiency. 
Jørgensen et al. (2008) reviewed literature on human resource management and continuous improvements and they developed a theoretical framework which described the role of human resource management in successful continuous improvements. They pointed out the importance of designing work processes to facilitate and enable generation of ideas and suggestions for improvement, continuing education both internal and external, knowledge sharing, and cooperation across organisational levels and customers and suppliers.

Stephenson et al. (2010) developed an Energy Cultures framework which focuses on the behaviour of individuals within the system. The individuals' behaviour provides a foundation for analysing which aspects of the system affect the energy behaviour the most. The results could be used to consider interventions that would successfully achieve behaviour change.

Organisational behaviour and behaviour change with regard to energy efficiency in the UK non-domestic sector have been studied (CSE, 2012). A conceptual framework was developed and further used to draw common understandings from the extensive literature reviewed in the study. Examples of themes studied were policies to improve energy efficiency behaviours, organisational strategies for improving energy efficiency, business investments in energy efficiency, barriers to implementing energy efficiency, non-energy benefits and differences between organisations.

\subsection{Barriers}

The research on barriers to improving industrial efficiency is important for exploring why energy efficiency measures fail to be implemented and to develop action plans to overcome these barriers. Sorrell (2000) classified barriers to energy efficiency into the following three categories: economic (which can be further divided into market failure and non-market failure), behavioural, and organisational, see Table 4. Palm and Thollander (2010) analysed and discussed these categories further, and Cagno et al. (2013) and Sudhakara Reddy (2013) proposed novel taxonomies of barriers that could be used in empirical studies. The study by Palm and Thollander (2010) categorised the internal barriers into technology-related barriers, information barriers, economic barriers, behavioural barriers, organisational barriers, and barriers related to competencies and awareness. The external barriers were categorised into markets, governmental politics, technology and services suppliers, designers and manufacturers, energy suppliers, and capital suppliers. The study by Sudhakara Reddy (2013) associated barriers and drivers to the institutions that create it and the institutions that are influenced by it. The barriers were classified as micro (obstacles that are unique to a particular project), meso (obstacles related to the organisation working with a project), and macro (barriers at state, market and civil society level). Fleiter et al. (2011) reviewed the current status of bottom-up models for industrial energy demand, and they analysed how these models considered barriers to the adoption of new technologies. Empirical studies on barriers to improved industrial energy efficiency have been conducted in Ghana (Apeaning and Thollander, 2013), Greece (Sardianou, 2008), Sweden (Rohdin and Thollander, 2006; Rohdin et al., 2007; Thollander et al., 2007; Thollander and Ottosson, 2008; Trianni et al., 2013a), Italy (Trianni et al., 2013a; Trianni et al., 2013b), Germany (Trianni et al., 2013a), the UK (Walsh and Thornley, 2012), and the Netherlands (De Groot et al., 2001). 
Table 4. Classification of barriers to improved energy efficiency. Source: Sorrell (2000); Thollander and Palm (2013)

\begin{tabular}{|c|c|c|c|}
\hline Category & Sub-division & Theoretical barrier & Description \\
\hline \multirow[t]{8}{*}{ Economic } & $\begin{array}{l}\text { Market or } \\
\text { organisational } \\
\text { failure }\end{array}$ & Imperfect information & $\begin{array}{l}\text { Individual lacks sufficient } \\
\text { information to make } \\
\text { economically efficient } \\
\text { decisions }\end{array}$ \\
\hline & & Adverse selection & $\begin{array}{l}\text { Individual has limited } \\
\text { knowledge of energy } \\
\text { performance of technology } \\
\text { and may select goods on the } \\
\text { sole basis on price or design }\end{array}$ \\
\hline & & Split incentives & $\begin{array}{l}\text { The individual or } \\
\text { department cannot benefit } \\
\text { from the investment, e.g. } \\
\text { department not accountable } \\
\text { for energy costs }\end{array}$ \\
\hline & & $\begin{array}{l}\text { Principal-agent } \\
\text { relationships }\end{array}$ & $\begin{array}{l}\text { Board of directors } \\
\text { (principal) may impose strict } \\
\text { investment criteria to } \\
\text { compensate for imperfect } \\
\text { information }\end{array}$ \\
\hline & $\begin{array}{l}\text { Non-market } \\
\text { failure/Rational } \\
\text { behaviour }\end{array}$ & Heterogeneity & $\begin{array}{l}\text { Technology may not be cost- } \\
\text { effective in a particular } \\
\text { instance }\end{array}$ \\
\hline & & Hidden costs & $\begin{array}{l}\text { Engineering model does not } \\
\text { reflect extra costs or loss of } \\
\text { benefits, e.g. overhead for } \\
\text { staff, disruption, hassle and } \\
\text { inconvenience }\end{array}$ \\
\hline & & Risk & $\begin{array}{l}\text { Investment criteria. Energy } \\
\text { efficiency investments may } \\
\text { be a higher risk than others }\end{array}$ \\
\hline & & Access to capital & $\begin{array}{l}\text { Limited access to capital } \\
\text { may inhibit cost-effective } \\
\text { investments }\end{array}$ \\
\hline
\end{tabular}


Table 4. (continued)

\begin{tabular}{|c|c|c|c|}
\hline Category & Sub-division & Theoretical barrier & Description \\
\hline \multirow[t]{5}{*}{ Behavioural } & $\begin{array}{l}\text { Bounded } \\
\text { rationality }\end{array}$ & Bounded rationality & $\begin{array}{l}\text { Decisions are based on } \\
\text { routines and rules of thumb } \\
\text { rather than perfect } \\
\text { information and complete } \\
\text { rationality }\end{array}$ \\
\hline & \multirow[t]{4}{*}{$\begin{array}{l}\text { The human } \\
\text { dimension }\end{array}$} & Form of information & $\begin{array}{l}\text { The information is } \\
\text { inadequate }\end{array}$ \\
\hline & & Credibility and trust & $\begin{array}{l}\text { The source of information is } \\
\text { not trusted }\end{array}$ \\
\hline & & Inertia & $\begin{array}{l}\text { Individuals resist change } \\
\text { because they are committed } \\
\text { to what they are doing }\end{array}$ \\
\hline & & Values & $\begin{array}{l}\text { Lack of environmental } \\
\text { awareness results in neglect } \\
\text { of efficiency opportunities }\end{array}$ \\
\hline \multirow[t]{2}{*}{ Organisational } & & Power & $\begin{array}{l}\text { Energy managers lack status } \\
\text { and authority }\end{array}$ \\
\hline & & Culture & $\begin{array}{l}\text { Environmental awareness } \\
\text { and energy efficiency are not } \\
\text { incorporated in company } \\
\text { culture }\end{array}$ \\
\hline
\end{tabular}

Barriers to low-grade heat recovery in industry have been identified as a lack of infrastructure, a lack of financial support, capital costs and problems associated with location (Walsh and Thornley, 2012).

\subsection{Driving forces}

Research on driving forces for improving industrial energy efficiency has not been as extensive as the research on barriers. However, identification and analysis of driving forces are important for understanding the process of adopting successful energy management. The actor-oriented taxonomy on barriers, developed by Sudhakara Reddy (2013), could be extended to studies on driving forces for improving energy efficiency. Sudhakara Reddy (2013) discussed some examples of drivers: awareness of energy efficient technologies, decrease in technology price levels, increase in energy prices, appealing and fashionable technology, non-energy benefits (e.g. energy security, job 
creation, improved competitiveness, indoor environment, comfort, health, safety and productivity), and environmental regulations. Empirical studies on driving forces for improved industrial energy efficiency have been published by for example (Apeaning and Thollander, 2013; Rohdin and Thollander, 2006; Rohdin et al., 2007; Thollander and Ottosson, 2008; Cagno and Trianni, 2013; Trianni et al., 2013a; Thollander et al., 2013). The main driving forces studied in these studies are presented in Table 5. The driving forces varied somewhat between the studies, e.g., the driving force "improving working conditions" was only found to be of major importance in the studies from Ghana and Thailand and not in the European studies. However, long-term energy strategy, environmental company profile, people with real ambition, and the threat of rising energy prices were considered important driving forces in the majority of the studies.

Table 5. Driving forces for improving energy efficiency in industry studied in previous research. The driving forces are not ranked.

\section{Driving force}

Threat of rising energy prices

Cost reduction from lowered energy use

Long-term energy strategy

People with real ambition

Network within the company/group

Environmental management system

Environmental company profile

International competition

Improving working conditions

\section{Key references}

Hasanbeigi et al. (2010); Apeaning and Thollander (2013); Thollander et al. (2013); Thollander and Ottosson (2008)

Apeaning and Thollander (2013);

Thollander and Ottosson (2008);

Christoffersen et al. (2006)

Apeaning and Thollander (2013);

Hasanbeigi et al. (2010); Rohdin et al. (2007); Thollander et al. (2013);

Thollander and Ottosson (2008)

Apeaning and Thollander (2013); Cagno and Trianni (2013); Rohdin et al. (2007); Thollander and Ottosson (2008)

Apeaning and Thollander (2013); Thollander et al. (2013); Thollander and Ottosson (2008)

Apeaning and Thollander (2013); Rohdin et al. (2007); Thollander and Ottosson (2008)

Apeaning and Thollander (2013); Hasanbeigi et al. (2010); Rohdin et al. (2007); Thollander et al. (2013);

Thollander and Ottosson (2008);

Christoffersen et al. (2006)

Rohdin et al. (2007); Thollander et al. (2013); Thollander and Ottosson (2008)

Apeaning and Thollander (2013);

Hasanbeigi et al. (2010) 
Table 5. (continued)

\section{Driving force}

Compliance with regulatory issues

Investment subsidies or beneficial loans

Customer questions and demand

Energy performance contracts

\section{Key references}

Apeaning and Thollander (2013); Cagno and Trianni (2013); Thollander and Ottosson (2008)

Thollander et al. (2013); Thollander and Ottosson (2008)

Cagno and Trianni (2013); Thollander et al. (2013)

Thollander and Ottosson (2008); Cagno and Trianni (2013)

\subsubsection{European directives and policy instruments}

This section gives an introduction to European directives and European policy instruments which could serve as a driving force for improved energy efficiency and reduced $\mathrm{CO}_{2}$ emissions in the iron and steel industry. European directives specify certain end results that the member states must achieve. However, national authorities are free to decide on how to meet these goals. Policy instruments are used by a government to achieve a desired effect. There are e.g. regulatory instruments such as laws and regulations, and economic instruments such as taxes and fees, subsidies and tradable permits (Thollander et al., 2012). Table 6 shows an overview of different energy and environmental policy instruments.

Table 6. Overview of different energy and environmental policy instruments (Swedish Energy Agency, 2014; Thollander et al., 2012).

\begin{tabular}{|c|c|c|c|}
\hline Administrative & Economic & Informative & Research \\
\hline Regulations & Taxes & Information & Research support \\
\hline $\begin{array}{l}\text { Limit values on } \\
\text { emissions }\end{array}$ & Tax reductions & Advisory service & Development support \\
\hline $\begin{array}{l}\text { Fuel type and energy } \\
\text { efficiency } \\
\text { requirements }\end{array}$ & Fees & Training & Demonstration support \\
\hline Long-term agreements & Subsidies/grants & Opinion formation & $\begin{array}{l}\text { Commercialisation } \\
\text { support }\end{array}$ \\
\hline \multirow[t]{2}{*}{$\begin{array}{l}\text { Environmental } \\
\text { classification }\end{array}$} & Sureties & & $\begin{array}{l}\text { Technology } \\
\text { procurement }\end{array}$ \\
\hline & $\begin{array}{l}\text { Market-based trading } \\
\text { systems }\end{array}$ & & \\
\hline
\end{tabular}


One of the European directives is the industrial emissions directive (IED). IED is a successor of the integrated pollution prevention and control (IPPC) directive and was entered into force on January 2011 (European Parliament, 2010). IED regulates pollution from industrial processes; industrial operations covered by Annex I must have permits for their emission. The permits have to consider the whole environmental performance of the plant, e.g. emissions to air, water and land, energy efficiency and use of raw materials. The emission limit must be based on BAT.

Under the renewable energy directive, EU member states have committed themselves to national targets of increasing the share of renewable energy by 2020 (European Parliament, 2009). The targets are set individually for each member state taking their different starting points into account. Sweden has set a target of 49\% renewables in 2020. The EU renewable energy target of 2020 as a whole is $20 \%$, with a $10 \%$ share of renewable energy in the transport sector. To meet the target, all sectors must investigate options to replace fossil fuels with renewable energy.

The EU adopted the energy efficiency directive (EED) on 25 October 2012 (European Parliament, 2012). The directive replaces the energy end-use efficiency and energy services directive (ESD). The EED provides a common framework of measures for improving energy efficiency in EU member states. Its objective is to remove market barriers and market failures that hinder efficient supply and use of energy. The EED states for example that each member state is obliged to set a national energy efficiency target. The target shall express absolute levels of primary energy use and final energy use in 2020.

One of the European policy instruments is the European Union Emission Trading System (EU ETS) (European Commission, 2013). The objective of the EU ETS is to reduce emissions of fossil GHGs cost-effectively. The EU ETS has been in operation since 2005 and involves the 28 EU countries, and Iceland, Liechtenstein and Norway. The EU ETS sets a limit to the total amount of GHGs that are allowed to be emitted from industry, power plants and other fixed installations in the participating countries. Companies receive or buy emissions allowances which they can trade with each other. The cap of total emissions is reduced over time which will result in reduced GHG emissions. A third phase has been launched for the years 2013-2020. This period differs some from the previous time periods and the main changes are:

- The new period has a single EU-wide cap; the previous time periods had national caps.

- Auctioning is now the default method for allocating allowances. However, in 2013, manufacturing industry will be given $80 \%$ of its allowances for free. This share of free allowances will gradually decrease and reach 30\% in 2020.

Manufacturing industry exposed to competition with companies outside the EU, e.g. the steel industry, will get a higher share of free allowances.

- More sectors and GHGs are included in the trading scheme.

In addition to the European policy instruments there are several national energy and environmental policy instruments in Sweden, e.g. $\mathrm{CO}_{2}$ taxes, energy taxes, the 
programme for improving energy efficiency in energy-intensive industry (PFE), the electricity certificate system, the environmental code and the energy auditing programme. However, industries that participate in the EU ETS are exempted from national $\mathrm{CO}_{2}$ taxes. A description of the Swedish policy instruments can be found in Swedish Energy Agency (2013b). 


\section{Systems studied}

This chapter describes the systems studied in the appended papers of this thesis.

\subsection{Industry sector of Gävleborg County}

In Paper II, the recovery potential of excess heat from industry in Gävleborg County was studied. Gävleborg County is located in central Sweden on the Baltic Sea coast. It is Sweden's tenth most populated county out of 21 counties. The county has a large share of energy-intensive industry and in 2010 the energy use in its industrial sector totalled 11.2 TWh (SCB, 2013). This was about 67\% of the energy end-use in Gävleborg County (Statistics Sweden, 2013). Information about available industrial excess heat flows in the county was taken from a questionnaire previously designed and sent out by Sarah Broberg Viklund and Sandra Backlund, Linköping University. The web-based questionnaire had been sent to 58 industrial firms in spring 2012. All the firms were classified $^{6}$ as firms holding a high environmental impact. The questionnaire had been answered by the person in charge of energy issues at the firms and the response rate was $33 \%$. The firms completing the questionnaire accounted for approximately $85^{7} \%$ of the annual use of energy within the industrial sector in the county.

\subsection{Swedish iron and steel industry}

In Paper VI, energy management practices at Swedish steel plants were studied and energy managers at 11 steel plants were interviewed. In Sweden there are 13 steel producing companies. Two of these produce steel from iron ore in BF-BOF, ten produce steel from scrap in EAF, and one produces iron powder from iron ore through direct reduction. In addition, there are 16 steel processing plants with only rolling mills, wire drawing, tube mills, etc. (Jernkontoret, 2014c). The location of the steel producing plants can be seen in Figure 11. All three steel plants which produce steel from iron ore, four scrap-based steel producers and four steel processing steel plants were included in the interview study in Paper VI.

${ }^{6}$ The classification was defined in: Ministry of the Environment. (1998) Constitution on environmental hazardous activities and health. 1998:899.

${ }^{7}$ In Paper II, this share was incorrectly reported as $62 \%$. 


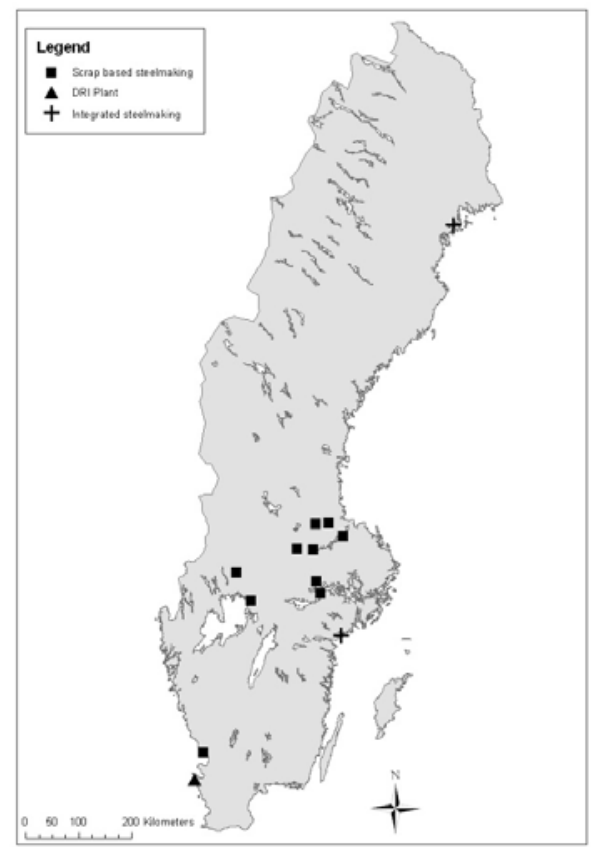

Figure 11. The location of Swedish steel plants. Pluses are iron ore based steel production in BF-BOF, the triangle is iron ore-based production of iron powder through direct reduction and squares are scrap-based steel production in EAF.

In 2013, 4.4 million tonnes of crude steel were produced in Sweden and about $60 \%$ of this was alloyed steel (Jernkontoret, 2014b). This is a high share compared to the situation in other countries. The Swedish Steel Producers' Association, Jernkontoret, is owned by Swedish steel companies and its main function is to "safeguard the interests of Swedish steel industry through working actively to ensure the best possible operating conditions for the industry in Sweden” (Jernkontoret, 2014a).

\subsection{SSAB in Luleå}

SSAB EMEA $^{8}$ is a leading producer of advanced high strength steel globally and Scandinavia's largest producer of strip products. SSAB EMEA has production facilities in Luleå, Borlänge and Oxelösund in Sweden. The facilities in Luleå and Oxelösund are the only iron ore-based steel plants with coke ovens and BF-BOF operation in Sweden. In Paper I, SSAB Luleå was used as an example in the study of energy efficiency measures and fuel substitution options for integrated steel plants. SSAB Luleå has a BF with capacity of 2.5 million tonnes crude iron per year. The steel plant has no rolling mill on

\footnotetext{
${ }^{8}$ SSAB's geographical business region in Europe, Middle East and Africa.
} 
site, but steel slabs are transported by train to the company's rolling mill in Borlänge. Excess process gases from SSAB Luleå are delivered to a CHP plant and used as fuel in the production of electricity and DH. In 2012, SSAB EMEA had 6,504 employees and annual turnover of MSEK 14,839 (SSAB, 2012). SSAB Luleå had 1,275 employees and annual turnover of MSEK 9,500 in 2012.

\subsection{Sandvik in Sandviken}

Sandvik AB is a high-technology engineering group with customers in more than 130 countries. One of its five business areas is Sandvik Materials Technology (SMT) with production facilities located in Sandviken in Gävleborg County, Sweden. SMT is a leading manufacturer globally of high value-added products such as tube, wire and strip in advanced materials. Sandvik in Sandviken produces steel from scrap in an EAF, an AOD converter and a ladle furnace, each with a charge-weight of 75 tonnes. In 2012, SMT had 7,300 employees and annual turnover of MSEK 15,366 (Sandvik AB, 2012). Sandvik in Sandviken had 4,600 employees. The company has a large production capacity and diversified production processes which offer several interesting cases to study. In Paper I, Sandvik in Sandviken was used as an example in the study of energy efficiency measures and fuel substitution options for scrap-based steel plants. In Paper IV and Paper V, the steel plant was used as a case company to analyse substitution of LPG with bio-syngas or bio-SNG as fuel in reheating furnaces. In this thesis, Sandvik in Sandviken is referred to as Sandvik.

\subsubsection{Gasification and methanation system at Sandvik in Sandviken}

In Paper IV, substitution of LPG with bio-syngas as fuel in reheating furnaces at Sandvik in Sandviken was studied. A partial fuel substitution and a full-scale fuel substitution were analysed. The gasification systems analysed were a $4 \mathrm{MW}_{\text {th }}$ fixed bed high temperature agent gasifier (HTAG) in the case of a partial fuel substitution and a 45 $\mathrm{MW}_{\text {th }}$ circulating fluidized bed gasifier (CFBG) in the case of a full-scale fuel substitution. Excess heat from the gasifier was assumed to be delivered to a DHS. Specifications of the gasifiers can be seen in Table 7 .

Table 7. Specifications of the biomass gasifiers used in the analysis in Paper IV.

\begin{tabular}{llllllll}
\hline Gasifier & $\begin{array}{l}\text { Biomass } \\
\text { input } \\
\left(\mathrm{MW}_{\text {th }}\right)\end{array}$ & $\begin{array}{l}\text { Operating } \\
\text { time, } \\
\text { (h/year })\end{array}$ & $\begin{array}{llll}\text { Oxidant } \\
\text { (hequired } \\
\text { moisture } \\
\text { content of } \\
\text { biomass }\end{array}$ & $\begin{array}{l}\text { Efficiency } \\
\text { Syngas }\end{array}$ & $\begin{array}{l}\text { Energy } \\
\text { DH } \\
\text { bio- } \\
\text { syngas } \\
\left(\mathrm{MJ} / \mathrm{Nm}^{3}\right)\end{array}$ \\
\hline HTAG & 4 & 8000 & Air & $<10 \%$ & 0.80 & $0.10-0.15$ & $6-8$ \\
CFBG & 45 & 8000 & Steam & $<10 \%$ & 0.80 & $0.10-0.15$ & $15-18$ \\
\hline
\end{tabular}

In Paper V, substitution of LPG with bio-SNG as fuel in Sandvik's reheating furnaces was studied. In the Biokombi Rya project (Chalmers Energy Centre, 2007), a gasification system had previously been designed to produce bio-SNG for export to a natural gas grid. Performance data for the gasifier in the Biokombi Rya project were used as input to the study in Paper V (Table 8). Figure 12 shows a schematic picture of the system with the 
steel plant and the gasification system. The gasifier studied was a pressurised, oxygenblown CFBG with a gas cleaning system comprised of a high temperature filter and catalytic tar reforming technology. CFBG is considered suitable for biomass gasification since it is rather insensitive to fuel quality. It was assumed that the gasifier operated $8000 \mathrm{~h} /$ year. The system studied included an air separation unit (ASU) for production of oxygen to the gasifier and a steam turbine for electricity production from excess heat from the gas cooling processes. It was assumed that excess heat from the gasification system could be delivered to a DHS all production hours.

Table 8. Performance data for the gasification and methanation system analysed in

Paper V. The capacity of the gasification system is $45 \mathrm{MW}_{\text {th }}$ and it operates at $43 \mathrm{MW}_{\text {th. }}$. The system includes a circulating fluidized bed gasifier, a gas cleaning system, a methanation reactor, an air separation unit (ASU) and a steam turbine. Data was based on (Chalmers Energy Centre, 2007).

\begin{tabular}{cclrllr}
\hline $\begin{array}{l}\text { Biomass input } \\
\left(\mathrm{MW}_{\text {th }}\right)\end{array}$ & $\begin{array}{l}\text { SNG output } \\
\left(\mathrm{MW}_{\text {bio-SNG }}\right)\end{array}$ & Electricity $\left(\mathrm{MW}_{\mathrm{e}}\right)$ & $\begin{array}{l}\text { DH production } \\
\left(\mathrm{MW}_{\text {heat }}\right)\end{array}$ & Efficiency & \\
\hline 43 & 27.6 & Demand: & 3.2 & 10.2 & SNG: & 0.64 \\
& & Production: & 2.4 & & Electricity: & -0.02 \\
& & Net production: & -0.8 & & DH: & 0.24 \\
\hline
\end{tabular}

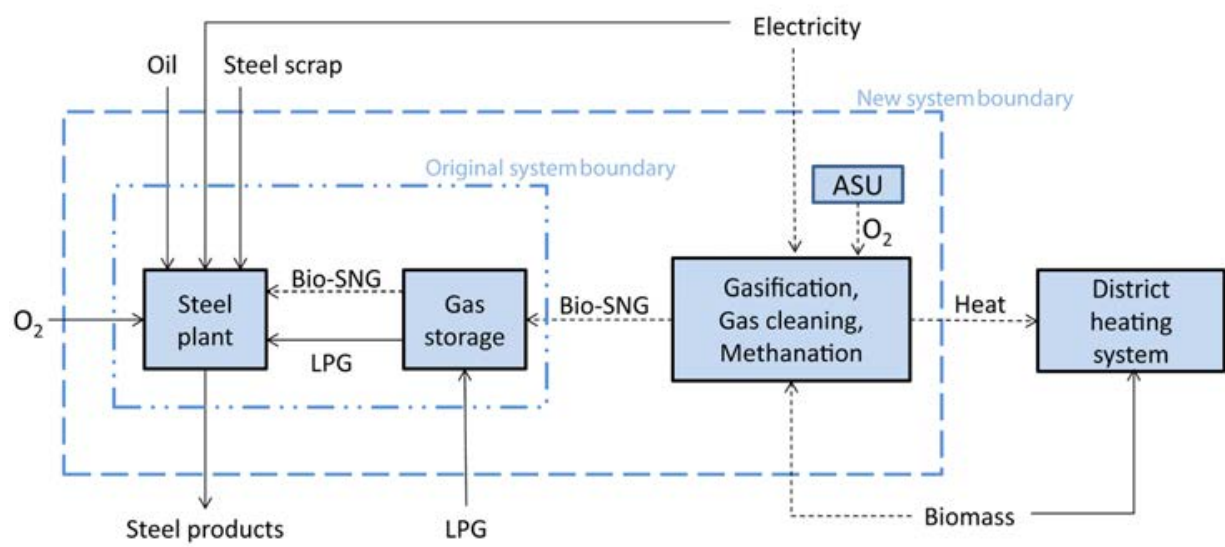

Figure 12. Schematic illustration of the system studied in Paper V. Dotted arrows are new energy flows introduced when the gasification system produces bio-SNG to the steel plant. 


\section{Methodology}

This chapter describes the methodologies and input data used in the analysis of this thesis.

Five of the papers in this thesis evaluate how energy recovery or fuel substitution would affect $\mathrm{CO}_{2}$ emissions. Paper I presents effects on direct fossil $\mathrm{CO}_{2}$ emissions, while the other papers analyse global $\mathrm{CO}_{2}$ emissions and include emissions from marginal electricity production. In Paper II, Paper IV and Paper V the fact that biomass can be seen as a limited resource is considered and alternative use of wood fuel is taken into consideration in the evaluation of global $\mathrm{CO}_{2}$ emissions. Sensitivity analysis of investment opportunity and effects on global $\mathrm{CO}_{2}$ emissions was conducted using future energy market scenarios (EMS). Table 9 shows an overview of which methodology is used in which of the appended papers.

Table 9. An overview of methodologies used in the appended papers.

\begin{tabular}{lcccccc} 
Methodology approach & Paper I & Paper II & Paper III & Paper IV & Paper V & Paper VI \\
\hline Economic analysis & & & $\mathrm{X}$ & & $\mathrm{X}$ & \\
Energy market scenarios & & $\mathrm{X}$ & & $\mathrm{X}$ & $\mathrm{X}$ & \\
$\mathrm{CO}_{2}$ emissions evaluation & $\mathrm{X}$ & $\mathrm{X}$ & $\mathrm{X}$ & $\mathrm{X}$ & $\mathrm{X}$ & \\
Interview & & & & & & $\mathrm{X}$ \\
\hline
\end{tabular}

\subsection{Energy market scenarios}

To assess profitability and net $\mathrm{CO}_{2}$ emissions reduction of future or long-term energyrelated investments it is important to consider possible developments of future energy market conditions. By using a number of different EMS that outline possible cornerstones of the future energy market, reliable results can be achieved. It is important that the energy market parameters within an EMS are consistent, i.e., the energy prices must be related to each other. The EMS used in Paper II, Paper IV and Paper V were generated by the Energy Price and Carbon Balance Scenarios tool (the ENPAC tool). The tool was developed at Chalmers University of Technology and a thorough description of the tool was presented by Axelsson and Harvey (2010) and Axelsson et al. (2009). The ENPAC tool proposes energy market prices for large-volume customers, based on European market fossil fuel prices and climate mitigation policy instruments. An overview of the 
ENPAC tool can be seen in Figure 13. Inputs to the tool are fossil fuel prices on the European commodity market and policy instruments. With these inputs, the potential marginal energy conversion technologies in the energy markets can be determined as well as end-user energy prices and $\mathrm{CO}_{2}$ emissions associated with marginal use of the energy carriers. The ENPAC tool has been used in a number of previous studies, see, for example, (Johansson et al., 2012; Wetterlund et al., 2011; Wetterlund and Söderström, 2010; Heyne and Harvey, 2013; Fahlén and Ahlgren, 2009).

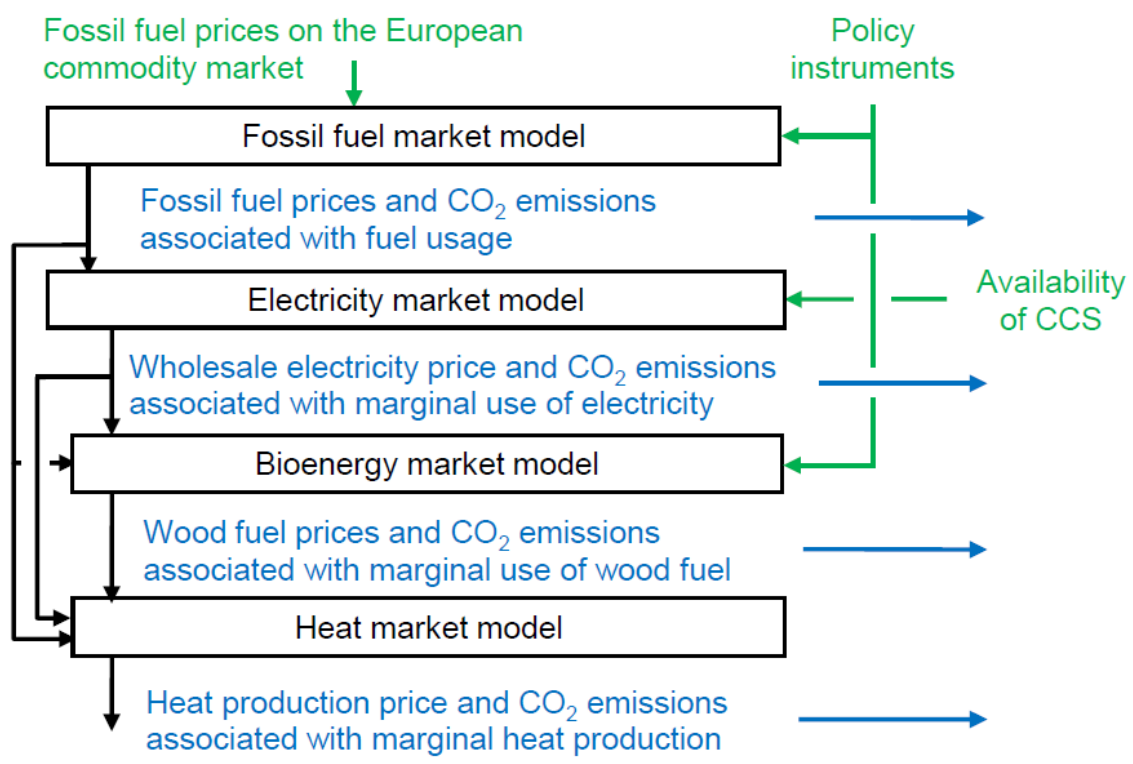

Figure 13. Overview of the ENPAC tool. Green arrows represent required input to the tool. Boxes represent calculation units for different energy markets. Black arrows represent information flow within the tool and blue arrows represent output from the tool, i.e., energy market. (Reprinted with the permission from Axelsson and Harvey (2010) p. 5)

In this thesis, it was assumed that in the time period analysed (2030) there would be a totally deregulated European market for electricity and biomass, while the market for DH would be determined by local conditions. In the ENPAC tool, build-margin technology for electricity generation was assumed to be CCP plants or natural gas combined cycle (NGCC) plants (Axelsson and Harvey, 2010). Biomass was limited to low and high grade wood fuels, e.g. forestry logging residues and wood pellets, and the ENPAC tool considered two potential marginal users of these wood fuels: CCP plants with wood fuel co-firing or producers of biofuels to the transport sector. Two types of Swedish DHS were considered: (1) DHS in which most of the heat was produced in bio-fuelled heat- 
only boilers ${ }^{9}$ (bio-HOB) and (2) DHS in which most of the heat was produced in biofuelled CHP (bio-CHP) plants ${ }^{10}$. The bio-HOB system and the bio-CHP system were assumed to represent small Swedish heat systems and large Swedish heat systems respectively. The value of delivering industrial excess heat to a DHS was set by the heat prices a new heat supplier would have to compete with.

\subsection{Economic evaluation}

In Paper III and Paper V, techno-economic evaluations have been performed. Investment data and technical performance of the electricity generating technologies analysed in Paper III have been attained through personal contact with manufacturers and suppliers and from supplier's websites. In Paper V, economic and technical specifications for the bio-SNG production plant were found in literature while information about the steel plant's productions processes, energy demand and energy costs were provided by personnel at the steel plant. Investment data for the gasification system was taken from Chalmers Energy Centre (2007) and was adjusted to the base year 2010 using the Chemical Engineering Plant Cost Index (CEPCI, 2011) and currency index. The gasification system was assumed to be scalable according to the general equation, Equation 1.

$$
\frac{C}{C_{\text {base }}}=\left[\frac{S}{S_{\text {base }}}\right]^{R}
$$

Equation 1

where $C$ is investment cost and $S$ is plant capacity for a new plant, and $C_{\text {base }}$ are known investment cost for a certain capacity, $S_{\text {base }}$. The scale up factor, $R$, was set to 0.7. This value is an average value for chemical processing plants (Remer and Chai, 1990).

Investment cost was discounted using the annuity method. For the electricity generating technologies in Paper III, a discount rate of $10 \%$ and a 15-year discount period were used, which generated a capital recovery factor (CRF) of 0.13 . For the gasification system in Paper V, a discount rate of $6 \%$ and a 20 -year discount period were used, which generated a CRF of 0.09. Investment in biomass gasification was seen as a strategic investment and therefore allowed to have a longer payback period. Paper V also contained a sensitivity analysis where the discount rate was increased to $12 \%$ (see Table 10).

In both papers net annual profit (NAP) was calculated for the investments. In Paper III, NAP for electricity production from low-temperature excess heat was calculated using Equation 2.

$$
\mathrm{NAP}=\mathrm{R}_{\mathrm{el}}-\mathrm{C}_{\mathrm{c}}-\mathrm{C}_{\mathrm{O} \& \mathrm{M}} \quad \text { Equation } 2
$$

where $R_{e l}$ is revenue for electricity production, $C_{c}$ is annual capital cost for the electricity production technology and $C_{O \& M}$ is annual operation and maintenance (O\&M) costs.

\footnotetext{
${ }^{9}$ Composition of heat production: $85 \%$ bio-HOB, $4 \%$ coal-HOB, $2 \%$ NG-HOB, $4 \%$ oil-HOB, $4 \%$ other renewables

${ }^{10}$ Composition of heat production: 54\% bio-CHP, 3\% coal-CHP, 28\% bio-HOB, $4 \%$ heat pumps, $6 \%$ NG-CHP, $1 \%$ coal-HOB, $1 \%$ NG-HOB, $1 \%$ oil-HOB, $1 \%$ other renewables
} 
In Paper V, two system costs were compared: (1) the existing system where the reheating furnaces are fuelled with LPG, and 2) a system where the steel plant has invested in a biomass gasifier and the reheating furnaces are fuelled with bio-SNG from the gasifier. NAP for the investment in a biomass gasifier and fuel substitution was calculated using Equation 3.

$$
\begin{aligned}
& \mathrm{NAP}=\mathrm{C}_{\text {system, } \mathrm{LPG}}-\mathrm{C}_{\text {system,SNG }}= \\
& \left(\mathrm{C}_{\mathrm{LPG}}+\mathrm{C}_{\text {el,vap }}\right)-\left(\mathrm{C}_{\text {invBG }}+\mathrm{C}_{0 \& \mathrm{M}, \mathrm{BG}}+\mathrm{C}_{\text {biomass }}+\mathrm{C}_{\mathrm{el}, \mathrm{BG}}-\mathrm{R}_{\mathrm{DH}}\right) \quad \text { Equation } 3
\end{aligned}
$$

where $C_{L P G}$ is annual cost for purchased LPG, $C_{e l \text {,vap }}$ is annual cost for electricity for vaporisation of LPG, $C_{i n v B G}$ is annual capital cost with regard to investment in a biomass gasification system, $C_{O \& M, B G}$ is annual O\&M costs for the biomass gasification system, $C_{\text {biomass }}$ is annual cost for biomass to the gasifier, $C_{e l, B G}$ is annual cost for electricity to the gasification system and $R_{D H}$ is annual revenue for sold heat to the DHS.

Additionally, net present value (NPV) was calculated for the electricity generation technologies studied in Paper III. NPV was calculated using Equation 4.

$$
\begin{array}{ll}
N P V=\sum_{t=0}^{T} \frac{R_{t}}{(1+i)^{t}} & \text { Equation } 4
\end{array}
$$

where $i$ is the discount rate and $R_{t}$ is the net cash flow during period $t$. Positive values for NPV infers that the investment would be profitable, and the higher the value, the more profitable the investment.

\subsubsection{Investment input data}

Economic data for the electricity generating technologies analysed in Paper III was taken from personal contact with suppliers of the technologies. Table 10 presents investment costs and O\&M costs used in the analysis.

Table 10. Economic data for three technologies that can be used to generate electricity from low-temperature excess heat.

\begin{tabular}{llll}
\hline & PCM engine & ORC & TEG \\
\hline Supplier & Exencotech AB & Opcon AB & TEG power \\
Size $(\mathbf{k W})$ & 750 & 750 & 0.200 \\
Investment cost & M€ 1.5 & M€ 1.2-1.3 & $€ 1,600$ \\
$\begin{array}{l}\text { O\&M costs } \\
\text { (€/year) }\end{array}$ & 27,000 & 11,300 & - \\
\hline
\end{tabular}

Economic data for the bio-SNG production plant analysed in Paper V was based on a report completed by Chalmers Energy Centre (2007). The investment costs and O\&M costs used in Paper V are presented in Table 11. The base case analysed was a $45 \mathrm{MW}_{\text {th }}$ gasification and methanation system, a discount rate of $6 \%$ and a discount period of 20 years. 
Table 11. Economic data for investment in a gasification system which produces bioSNG from wood pellets. The system includes a CFB gasifier, a gas cleaning system, a methanation reactor, an air separation unit (ASU) and a steam turbine. Data was based on Chalmers Energy Centre (2007). $1 €=8.88$ SEK

\begin{tabular}{|c|c|c|c|c|c|c|c|}
\hline $\begin{array}{l}\text { Biomass } \\
\text { input } \\
\text { capacity }\end{array}$ & $45 \mathrm{MW}_{\text {th }}$ & $45 \mathrm{MW}_{\text {th }}$ & $55 \mathrm{MW}_{\text {th }}$ & $55 \mathrm{MW}_{\text {th }}$ & $45 \mathrm{MW}_{\text {th }}$ & $45 \mathrm{MW}_{\text {th }}$ & \\
\hline $\begin{array}{l}\text { Discount } \\
\text { rate }\end{array}$ & 6 & 12 & 6 & 12 & 6 & 6 & $\%$ \\
\hline \multicolumn{8}{|l|}{ Investment } \\
\hline $\begin{array}{l}\text { TIC (total } \\
\text { investment } \\
\text { cost) }\end{array}$ & 75.5 & 75.5 & 86.9 & 86.9 & $60.4^{\mathrm{a}}$ & $45.3^{\mathrm{b}}$ & M€ \\
\hline Capital cost & 6.6 & 10.1 & 7.6 & 11.6 & 5.3 & 3.9 & M€/year \\
\hline \multicolumn{8}{|l|}{$\begin{array}{l}\text { Operation } \\
\text { and } \\
\text { maintenance }\end{array}$} \\
\hline $\begin{array}{l}\text { Fixed cost } \\
\text { (3.5\% of } \\
\text { TIC/year) }\end{array}$ & 2.6 & 2.6 & 3.0 & 3.0 & 2.1 & 1.6 & M€/year \\
\hline $\begin{array}{l}\text { Variable } \\
\text { cost }\end{array}$ & 3.6 & 3.6 & 3.6 & 3.6 & 3.6 & 3.6 & $\begin{array}{l}€ / \mathrm{MWh} \\
\text { biomass }_{\text {input }}\end{array}$ \\
\hline
\end{tabular}

\subsubsection{Data for energy markets scenarios}

In Paper V, EMS were used to evaluate future investments in a biomass gasifier and fuel substitution at the steel plant. The EMS were generated by the ENPAC tool and can be seen in Table 12. Inputs to the ENPAC tool were fossil fuel prices and $\mathrm{CO}_{2}$ emissions charges on the European commodity market, taken from World Energy Outlook 2011 (IEA, 2011) which represents the current policies (CP) scenario, the new policies (NP) scenario and the $450 \mathrm{ppm}^{11}$ scenario. The global scenarios in World Energy Outlook were developed by the International Energy Agency (IEA). The CP scenario assumes that no new policies are added to those in place in 2011, whereas the NP scenario assumes that recent policy commitments (made up to the year 2011) are supposed to be implemented. The $450 \mathrm{ppm}$ scenario is based on a global energy pathway that with a $50 \%$ chance could meet the goal of limiting the increase in global mean temperature to $2{ }^{\circ} \mathrm{C}$ above preindustrial levels. This goal could be reached if the long-term concentration of GHGs in the atmosphere is limited to $450 \mathrm{ppm}$ of $\mathrm{CO}_{2}$-eq.

\footnotetext{
${ }^{11} \mathrm{ppm}$ is abbreviation for parts per million
} 
Table 12. Prices used in the energy market scenarios (EMS) for 2030 with a monetary value of 2010. The prices that are output from the ENPAC tool are enduser prices, including $\mathrm{CO}_{2}$ charge. Input to the ENPAC tool was fossil fuel prices and $\mathrm{CO}_{2}$ emissions charges taken from World Energy Outlook 2011 (IEA, 2011) which represents the current policies scenario (input to EMS-1), the new policies scenario (input to EMS-2) and the 450 ppm scenario (input to EMS-3).

\begin{tabular}{|c|c|c|c|}
\hline \multicolumn{4}{|c|}{ Input data to the ENPAC tool } \\
\hline Scenario in World Energy Outlook 2011 & $\mathrm{CP}$ & NP & $450 \mathrm{ppm}$ \\
\hline \multicolumn{4}{|l|}{ Fossil fuel prices } \\
\hline Crude oil (\$/barrel) & 135 & 117 & 97 \\
\hline Natural gas (\$/Mbtu) & 13 & 12 & 10 \\
\hline Coal (\$/tonne) & 116 & 109 & 74 \\
\hline $\mathrm{CO}_{2}$ charge, EU-ETS (€/tonne) & 30 & 30 & 72 \\
\hline Support for renewable electricity ${ }^{\mathrm{a}}\left(€ / \mathrm{MWh}_{\mathrm{e}}\right)$ & 20 & 20 & 20 \\
\hline \multicolumn{4}{|l|}{ Support for renewable fuel ${ }^{\mathrm{a}}\left(€ / \mathrm{MWh}_{\text {fuel }}\right)$} \\
\hline Substitute for diesel & 26 & 26 & 26 \\
\hline Substitute for petrol & 35 & 35 & 35 \\
\hline \multicolumn{4}{|c|}{ Output from the ENPAC tool } \\
\hline Energy market scenario (EMS) & 1 & 2 & 3 \\
\hline Build-margin technology for electricity & $C C P^{b}$ & $C C P^{b}$ & $N G C C^{C}$ \\
\hline Marginal user of wood fuel & $F T^{d}$ & $F T^{d}$ & $C C P^{e}$ \\
\hline \multicolumn{4}{|l|}{ Energy prices } \\
\hline $\operatorname{LPG}\left(€ / M W h_{\text {fuel }}\right)$ & 103 & 94 & 94 \\
\hline Wood pellets ( $\left.€ / \mathrm{MWh}_{\text {fuel }}\right)$ & 52 & 47 & 57 \\
\hline Electricity $\left(€ / \mathrm{MWh}_{\mathrm{e}}\right)$ & 68 & 67 & 86 \\
\hline \multicolumn{4}{|l|}{ Industrial excess heat, sales price $\left(€ / \mathrm{MWh}_{\text {heat }}\right)$} \\
\hline Bio-HOB in Sweden & 43 & 39 & 47 \\
\hline Bio-CHP in Sweden & 18 & 12 & 15 \\
\hline
\end{tabular}

${ }^{a}$ European average value

${ }^{\mathrm{b}}$ Coal condensing power plant

${ }^{\mathrm{c}}$ Natural gas combined cycle

${ }^{\mathrm{d}}$ Producer of FT diesel

${ }^{\mathrm{e}}$ Coal condensing power plant with co-firing of wood fuel

\section{3 $\mathrm{CO}_{2}$ emissions evaluation and input data}

In Paper II-V effects on global $\mathrm{CO}_{2}$ emissions were investigated. Marginal electricity was assumed for changes in electricity production and use. Biomass was seen as a limited resource on the European market and alternative use of wood fuel was considered. Scenario analysis was used in Paper II, Paper IV and Paper V to be able to consider possible developments of future energy market conditions. Consistent EMS for the analysis were generated by the ENPAC tool and output from the tool was $\mathrm{CO}_{2}$ emissions factors for fossil fuels, wood fuel, electricity and heat. The emissions factors depend on the build-margin technology for electricity production, the marginal user of wood fuel and the type of heat production in the DHS. In Paper IV, an earlier version of the ENPAC tool was used and other price levels were used as input to the tool. Axelsson and Pettersson (2014) provide a summary of recent updates of the ENPAC tool during 
2011-2014. To facilitate a combined analysis of the results from all three abovementioned papers, the results from Paper IV have been recalculated using the same EMS as in Paper II and Paper V. The $\mathrm{CO}_{2}$ emissions factors used in the calculations of effects on global $\mathrm{CO}_{2}$ emissions can be seen in Table 13.

Table 13. $\mathrm{CO}_{2}$ emissions factors for the energy carriers analysed in Paper II, Paper IV and Paper V. Input to the ENPAC tool was fossil fuel prices and $\mathrm{CO}_{2}$ emissions charges taken from World Energy Outlook 2011 (IEA, 2011) which represents the current policies scenario (input to EMS-1), the new policies scenario (input to EMS-2) and the 450 ppm scenario (input to EMS-3). Prices are for year 2030 but in the monetary value of 2010 .

\begin{tabular}{|c|c|c|c|}
\hline \multicolumn{4}{|c|}{ Input data to the ENPAC tool } \\
\hline Scenario in World Energy Outlook 2011 & $\mathrm{CP}$ & NP & $450 \mathrm{ppm}$ \\
\hline \multicolumn{4}{|l|}{ Fossil fuel prices } \\
\hline Crude oil (\$/barrel) & 135 & 117 & 97 \\
\hline Natural gas (\$/Mbtu) & 13 & 12 & 10 \\
\hline Coal (\$/tonne) & 116 & 109 & 74 \\
\hline $\mathrm{CO}_{2}$ charge, EU-ETS (€/tonne) & 30 & 30 & 72 \\
\hline Support for renewable electricity ${ }^{\mathrm{a}}\left(€ / \mathrm{MWh}_{\mathrm{e}}\right)$ & 20 & 20 & 20 \\
\hline \multicolumn{4}{|l|}{ Support for renewable fuel ${ }^{\mathrm{a}}\left(€ / \mathrm{MWh}_{\text {fuel }}\right)$} \\
\hline Substitute for diesel & 26 & 26 & 26 \\
\hline Substitute for petrol & 35 & 35 & 35 \\
\hline \multicolumn{4}{|c|}{ Output from the ENPAC tool } \\
\hline Energy market scenario (EMS) & 1 & 2 & 3 \\
\hline Build-margin technology for electricity & $C C P^{b}$ & $C C P^{b}$ & $N G C C^{c}$ \\
\hline Marginal user of wood fuel & $F T^{d}$ & $F T^{d}$ & $C C P^{e}$ \\
\hline \multicolumn{4}{|l|}{$\mathrm{CO}_{2}$ emissions factor } \\
\hline LPG (kg CO $\left.2 / \mathrm{MWh}_{\text {fuel }}\right)$ & 245 & 245 & 245 \\
\hline Biomass (kg CO $\left./ \mathrm{MWh}_{\text {fuel }}\right)$ & 118 & 118 & 356 \\
\hline Electricity $\left(\mathrm{kg} \mathrm{CO}_{2} / \mathrm{MWh}_{\mathrm{e}}\right)$ & 714 & 714 & 340 \\
\hline \multicolumn{4}{|l|}{ District heating ( $\left.\mathrm{kg} \mathrm{CO} 2 / \mathrm{MWh}_{\text {heat }}\right)$} \\
\hline Bio-HOB in Sweden & 150 & 150 & 363 \\
\hline Bio-CHP in Sweden & -20 & -20 & 351 \\
\hline
\end{tabular}

\footnotetext{
${ }^{\mathrm{a}}$ European average value

${ }^{\mathrm{b}}$ Coal condensing power plant

${ }^{\mathrm{c}}$ Natural gas combined cycle

${ }^{\mathrm{d}}$ Producer of FT diesel

${ }^{\mathrm{e}}$ Coal condensing power plant with co-firing of wood fuel
}

Increased production of DH in a Swedish bio-CHP system would according to Table 12 reduce global $\mathrm{CO}_{2}$ emissions in EMS 1 and 2. The main reason for this is that the additional electricity produced in the system (electricity and heat are cogenerated) is assumed to replace electricity production in CCP plants, which has specific fossil $\mathrm{CO}_{2}$ emissions of $714 \mathrm{~kg} / \mathrm{MWh}_{\mathrm{e}}$. 


\subsection{Interviews}

The study in Paper VI is of explorative nature and aims to answer questions like 'How' and 'Why'. For that kind of study, a qualitative research method is appropriate. In-depth interviews are a qualitative research method that is suitable to use when eliciting detailed information from relatively few persons (Kvale, 1996). Therefore, in-depth interviews were used in Paper VI, to gain a deeper understanding of how energy managers at Swedish steel plants perceive their own and their companies' efforts to improve energy efficiency. The interviews were semi-structured and thus allowed for follow-up questions and discussion. Interviews with energy managers from 11 Swedish steel plants were conducted. The interviews were completed in Swedish, face-to-face at the respondents' companies and lasted on average 60 minutes. All interviews were audio-recorded and transcribed in full and the interviewees are anonymised in the thesis. An English translation of the interview guide can be found in Appendix 1. The interviewees were members of the Energy Council at Jernkontoret and they were selected due to this membership and the fact that they were responsible for energy issues at their companies. The council serves as a meeting place for energy managers at Swedish steel plants and one of the objectives of the study was to investigate the importance of networking between energy managers. Of the selected steel plants, seven had their own steel production and four only performed forming and shaping processes. The number of employees at the plants ranged between 65 and 4,600, and the annual energy use ranged between $4 \mathrm{GWh}$ and $11 \mathrm{TWh}$. The respondents had been employed at their companies between 4 and 40 years and the majority were engineers.

Analysis of the interviews was performed by identifying themes and categories that could answer the research questions. By finding common themes and categories it was possible to compare and analyse the interview data. Some of the categories found were: implemented measures, barriers, future prospects, energy vision, organisation with regard to energy issues, resources, authority of the energy manager, information to employees, awareness, and cooperation.

In the interviews, the respondents gave subjective views on the subjects discussed, and other persons at the company might have a different opinion. At the same time, the positions of the interviewees and the fact that they influenced the company's work with energy efficiency measures made them interesting actors to interview. Results from the study could not be generalised to the whole iron and steel industry, but could serve as an indication of how energy management in Swedish steel industry is performed. Moreover, results from the study could be used to give recommendations on how to accomplish efficient energy management. 


\section{Results and analysis}

This chapter presents the main findings of the appended papers. It starts with an overview of energy recovery and fuel substitution options for the iron and steel industry. Then the chapter continues with a study on recovery of industrial excess heat and in particular excess heat from the steel industry. Options to convert from fossil fuels to bio-syngas or bio-SNG are presented and analysed and the importance of efficient energy management for improving energy efficiency in the Swedish iron and steel industry are analysed.

\subsection{Energy recovery and fuel substitution}

There are several options for the iron and steel industry to utilise its energy flows more efficiently and to substitute fossil fuels with renewable alternatives and hence become more climate neutral. Paper I presents opportunities for integrated steel plants and scrapbased steel plants to improve their energy efficiency and to substitute fossil fuels with biomass. Paper II and III analyse technologies for the recovery and utilisation of industrial excess heat. Table 14 presents results from Paper I and Paper II and gives an overview of different measures that could be implemented at a steel plant to improve energy efficiency and reduce $\mathrm{CO}_{2}$ emissions. Integrated steel plants have more options to consider as the processes of integrated iron and steelmaking are more complex than scrap-based steelmaking. Both integrated and scrap-based steel plants have excess heat flows in flue gases, cooling water and hot materials. Industrial excess heat could be utilised for heating purposes or converted into other energy forms. When considering how excess heat recovery affects global $\mathrm{CO}_{2}$ emissions, it is not obvious which would be the most efficient recovery measure. This depends on the energy market, i.e., the marginal electricity producer and the marginal user of wood fuel. This is analysed in Section 9.2.2.

Integrated steel plants are more fossil fuel dependent than scrap-based steel plants, but have more options to convert to renewable alternatives. For example, large amounts of fossil coal are used as reducing agent in the blast furnace and part of that coal can be replaced with charcoal. However, as the coke acts as a physical support material and ensures gas permeability and process drainage it is not possible to substitute all the coke in large blast furnaces. The fossil pulverised injection coal could be substituted with pulverised charcoal. However, the charcoal is more porous than fossil coal which may hinder high injection rates through the tuyères (Feliciano-Bruzual and Mathews, 2013). Both integrated and scrap-based steel plants have the opportunity to substitute fossil fuels in reheating furnaces with syngas or SNG produced from biomass. It is not obvious that substitution of fossil fuels with biomass in the steel industry results in reduced global $\mathrm{CO}_{2}$ emissions. Again, this depends on the energy market (see Section 9.3.2). 
Table 14. Energy efficiency and fuel substitution options for integrated and scrapbased steel plants.

\begin{tabular}{|c|c|c|c|c|c|}
\hline Measure & $\begin{array}{l}\text { Integrated } \\
\text { steel } \\
\text { plant }\end{array}$ & $\begin{array}{l}\text { Scrap- } \\
\text { based } \\
\text { steel } \\
\text { plant }\end{array}$ & Resource & Product/Effect & Efficiency \\
\hline $\begin{array}{l}\text { Process gases for } \\
\text { CHP production }\end{array}$ & $x$ & & $\begin{array}{l}\text { COG, BFG, } \\
\text { BOFG }^{\mathrm{a}}\end{array}$ & $\begin{array}{l}\text { Electricity/Steam/District } \\
\text { heating }\end{array}$ & $\begin{array}{l}28 \% \text { electricity } \\
\text { efficiency, } 71 \% \\
\text { total efficiency, } \\
\alpha=0.66^{b}\end{array}$ \\
\hline $\begin{array}{l}\text { Hot water from } \\
\text { cooling beds }\end{array}$ & $x$ & $x$ & Heat & $\begin{array}{l}\text { Hot tap water, heat to } \\
\text { production processes, } \\
\text { local space heating } \\
\text { and/or district heating } \\
\text { systems }\end{array}$ & $\begin{array}{l}\text { Depends on the } \\
\text { configuration }\end{array}$ \\
\hline Absorption cooling & $x$ & $x$ & Heat & Cooling & $\begin{array}{l}\text { Coefficient of } \\
\text { performance } \\
\text { (COP) } 0.5-0.8^{c}\end{array}$ \\
\hline $\begin{array}{l}\text { Organic Rankine } \\
\text { cycle (ORC) }\end{array}$ & $x$ & $x$ & Heat & Electricity & $\begin{array}{l}5-20 \%{ }^{d} \\
\text { electricity } \\
\text { efficiency }\end{array}$ \\
\hline Kalina cycle & $x$ & $x$ & Heat & Electricity & $\begin{array}{l}12-17 \%{ }^{\mathrm{e}} \\
\text { electricity } \\
\text { efficiency }\end{array}$ \\
\hline $\begin{array}{l}\text { Thermoelectric } \\
\text { generator (TEG) }\end{array}$ & $x$ & $x$ & Heat & Electricity & $\begin{array}{l}1-5 \%{ }^{f} \text { electricity } \\
\text { efficiency }\end{array}$ \\
\hline Stirling engine & $x$ & $x$ & Heat & Electricity & $\begin{array}{l}13-36 \%^{\mathrm{g}} \\
\text { electricity } \\
\text { efficiency }\end{array}$ \\
\hline $\begin{array}{l}\text { Phase change } \\
\text { material (PCM) } \\
\text { engine }\end{array}$ & $x$ & $x$ & Heat & Electricity & $\begin{array}{l}2.5-9 \%{ }^{\mathrm{f}} \\
\text { electricity } \\
\text { efficiency }\end{array}$ \\
\hline $\begin{array}{l}\text { Thermophotovoltaic } \\
\text { (TPV) }\end{array}$ & $x$ & $x$ & $\begin{array}{l}\text { Heat } \\
\text { (Infrared } \\
\text { radiation) }\end{array}$ & Electricity & $\begin{array}{l}4.7-20 \%{ }^{\mathrm{h}} \\
\text { electricity } \\
\text { efficiency }\end{array}$ \\
\hline $\begin{array}{l}\text { Top pressure } \\
\text { recovery turbine } \\
\text { (TRT) }\end{array}$ & $x$ & & $\begin{array}{l}\text { Heat and } \\
\text { pressure }\end{array}$ & Electricity & $\begin{array}{l}40-60 \mathrm{kWh} \\
\text { electricity/tonne } \\
\text { of iron }\end{array}$ \\
\hline $\begin{array}{l}\text { Coke dry quenching } \\
\text { (CDQ) }\end{array}$ & $x$ & & Heat & $\begin{array}{l}\text { Heat recovery (Steam, } \\
\text { electricity) }\end{array}$ & $\begin{array}{l}35 \%{ }^{\mathrm{j}} \text { heat } \\
\text { recovery }\end{array}$ \\
\hline
\end{tabular}




\begin{tabular}{|c|c|c|c|c|c|}
\hline Measure & $\begin{array}{l}\text { Integrated } \\
\text { steel } \\
\text { plant }\end{array}$ & $\begin{array}{l}\text { Scrap- } \\
\text { based } \\
\text { steel } \\
\text { plant }\end{array}$ & Resource & Product/Effect & Efficiency \\
\hline $\begin{array}{l}\text { Methane reforming } \\
\text { of coke oven gas }\end{array}$ & $x$ & & $\mathrm{COG}^{\mathrm{a}}$ & Syngas (Methanol) & $\begin{array}{l}56-67 \%^{k} \\
\text { methanol } \\
\text { conversion } \\
\text { efficiency }\end{array}$ \\
\hline $\begin{array}{l}\text { Biomass as reducing } \\
\text { agent }\end{array}$ & $x$ & & $\begin{array}{l}\text { Charcoal, } \\
\text { biomethane } \\
\text { etc. }\end{array}$ & $\mathrm{CO}_{2}$ emission mitigation & $N / A$ \\
\hline $\begin{array}{l}\text { Biomass as fuel in } \\
\text { reheating furnaces }\end{array}$ & $x$ & $x$ & $\begin{array}{l}\text { Syngas/SNG } \\
\text { from } \\
\text { biomass }\end{array}$ & $\mathrm{CO}_{2}$ emission mitigation & $\mathrm{N} / \mathrm{A}$ \\
\hline $\begin{array}{l}\text { Direct reduced iron } \\
\text { (DRI) production }\end{array}$ & $x$ & $x$ & $\begin{array}{l}\text { Iron ore, } \\
\text { syngas/COG }\end{array}$ & DRI & N/A \\
\hline $\begin{array}{l}\text { Thermal energy } \\
\text { storage (TES) }\end{array}$ & $x$ & $x$ & Heat & Heat & $\mathrm{N} / \mathrm{A}$ \\
\hline Industrial symbiosis & $x$ & $x$ & $\begin{array}{l}\text { Energy, } \\
\text { materials, } \\
\text { water, } \\
\text { information }\end{array}$ & $\begin{array}{l}\text { Efficient use of resources } \\
\text { and } \mathrm{CO}_{2} \text { emission } \\
\text { mitigation }\end{array}$ & $N / A$ \\
\hline
\end{tabular}

${ }^{\mathrm{a}} \mathrm{COG}=$ Coke oven gas, $\mathrm{BFG}=$ Blast furnace gas, $\mathrm{BOFG}=$ Basic oxygen furnace gas.

${ }^{\mathrm{b}}$ Energy input in this example is 12\% COG, 68\% BFG, 17\% BOFG and 3\% oil (Lulekraft AB, 2010)

${ }^{\mathrm{c}}$ Lindmark (2005); Rydstrand et al. (2004); Srikhirin et al. (2001)

${ }^{\mathrm{d}}$ Velez et al. (2012)

${ }^{\text {e }}$ Asp et al. (2008); Ogriseck (2009)

${ }^{\mathrm{f}}$ Johansson and Söderström (2013)

${ }^{\mathrm{g}}$ Persson and Olsson (2002); Rogdakis et al. (2012); Chen et al. (2012); Cool Energy Inc (2013)

${ }^{\mathrm{h}}$ Bauer et al. (2004); Qiu and Hayden (2014)

${ }^{\mathrm{i}} \mathrm{Xu}$ and Cang (2010)

${ }^{\mathrm{j}}$ Zeng et al. (2009)

${ }^{\mathrm{k}}$ Lundgren et al. (2008)

Implementation of one of the technologies listed in Table 14 may affect the implementation potential of another. As an example, process gases for CHP production reduce the amount of COG available for methane reforming and vice versa. COG could also be used as reducing agent in a DRI process and the DRI could be charged into the BF as high-quality iron feedstock, into the BOF as cooling agent or into an EAF, substituting scrap. In conclusion, the three above-mentioned technologies compete for process gases as a resource. The technologies using heat as source of energy could compete or coexist. TPV systems could use heat sources with temperatures higher than $1000^{\circ} \mathrm{C}$ (e.g. hot flue gases, hot material such as steel products and slag) and heat losses from this system (e.g. cooling water) could serve as input to DHS, thermal energy storage (TES), absorption cooling, ORC, Kalina cycle, PCM engine, Stirling engine or TEG. Coke dry quenching (CDQ) and top pressure recovery turbine (TRT) do not compete with other technologies 
presented here. The most common practice is to cool hot coke from coke ovens with water in quenching towers, but in the CDQ process the coke is cooled with an inert gas in dry cooling plants. The hot quenching gas could then be used to generate steam, electricity and DH. TRT uses heat and pressure in BFG to produce electricity. TRT systems are installed at BF after gas cleaning equipment. Conventionally, the pressure of the BFG is reduced at a septum valve without any energy recovery. However, with the TRT the BFG expands in a turbine to reduce the pressure. The mechanical energy from the turbine generates electricity in a generator. Thermal solar panels or arrays of waterfilled copper pipes could be placed at cooling beds to recover radiation heat from hot steel products (Nilsson, 2003; Tarrés et al., 2014). The hot water produced could be used to heat buildings at the steel plant or be delivered to DHS. Heat recovery with thermal solar panels could prevent heat recovery with TPV. However, often steel beams and tubes on cooling beds have temperatures below $1000^{\circ} \mathrm{C}$, which means that in these cases TPV is not applicable. The electricity generating technologies ORC, Kalina cycle and PCM engine can all use cooling water with temperatures below $100^{\circ} \mathrm{C}$ as heat source, which means that implementation of one of these may affect the implementation potential of the other. However, the PCM engine is the only technology (of the above mentioned) which can use heat sources with temperatures down to $25^{\circ} \mathrm{C}$ to produce electricity. Utilising excess heat from the steel plant as $\mathrm{DH}$ means that there would be less heat available for electricity production and vice versa. The iron and steel industry has large amounts of cooling water with temperatures around $40^{\circ} \mathrm{C}$. The temperature is too low for $\mathrm{DH}$, but the cooling water could be used to heat e.g. greenhouses.

\subsection{Recovery of industrial excess heat}

In Paper II, untapped industrial excess heat potential in Gävleborg County was investigated and different options for recovery and utilisation of the heat were analysed. Measures for the recovery of industrial excess heat were grouped into four categories: heat harvesting, heat storage, heat utilisation and heat conversion. Heat harvesting equipment (heat exchangers, heat pumps and heat radiation collectors) can be used to transfer the excess heat from the heat source to another medium more suited for subsequent heat storage or heat utilisation. Heat exchangers and heat pumps are commercial technologies but heat radiation collectors have not commonly been used in applications for industrial excess heat recovery. There are a few examples of thermal collectors that have been used to recover heat radiation from cooling beds in steel industry, see for example Nilsson (2003) and Tarrés et al. (2014).

When the dynamics of the excess heat production do not match the dynamics of the heat demand or when the excess heat generation is larger than the heat demand, heat storage technologies can be used to store the heat for later use or to transport the heat to suitable heat sinks in other areas. There are three mechanisms for thermal energy storage (TES) (Tian and Zhao, 2013): sensible heat storage, latent heat storage and chemical heat storage. In sensible heat storage the temperature of the storage material (solid or liquid) is elevated when storing heat. An example of a simple sensible heat storage system is an insulated water tank. Latent heat storage involves phase changes of a PCM. During heat storage the PCM melts without any significant temperature increase of the material. Examples of PCMs are paraffin and inorganic salts. In chemical heat storage, heat is 
stored as chemical energy through endothermic chemical reactions and can be released in the reverse exothermic reaction.

The excess heat can be used for heating purposes at the industry or be transported to DHS outside the industry or to other industries and facilities with a heat demand. Excess heat is considered a very low-cost source of energy, which implies that energy conversion to electricity could be advantageous despite low conversion efficiencies. The heat-driven electricity generation technologies analysed in this thesis (see Table 13 in Section 9.1) are at different stages of development ${ }^{12}$, from research and development to commercial.

The untapped excess heat potential in Gävleborg County, reported by the firms answering the questionnaire, totalled approximately $0.8 \mathrm{TWh} /$ year. This potential represents $8.4 \%$ of the energy use among the firms that completed the questionnaire and $7.1 \%$ of the energy use in the industrial sector in Gävleborg County. Reported industrial excess heat sources were hot flue gases, hot air, cooling water and hot material, see Figure 14. Although these heat sources were reported by different industry sectors, they could also be found in the iron and steel industry and the recovery options could therefore be of interest for this industry sector. Because not all the firms completed the questionnaire, the excess heat potential in Gävleborg County is probably underestimated. Moreover, it is likely that some of the firms that completed the questionnaire did not report all their excess heat flows, but only those which they had quantified. As an example, steel companies in the county did not report heat in hot materials as a source of excess heat. These companies have steel production in EAF and obviously there are hot materials such as hot steel slabs, ingots and slag. If these heat sources would have been included in the analysis the potential would probably be much larger.

\footnotetext{
${ }^{12}$ Research and development scale is the first stage of development in which a method is experimentally tested. The next stage, the pilot scale, is a small production facility operating at a modest throughput, designed to prove or test a method. Demonstration scale is bigger in operation than a pilot plant, but smaller than a commercial plant. It is designed to demonstrate the commercial feasibility of a process.
} 


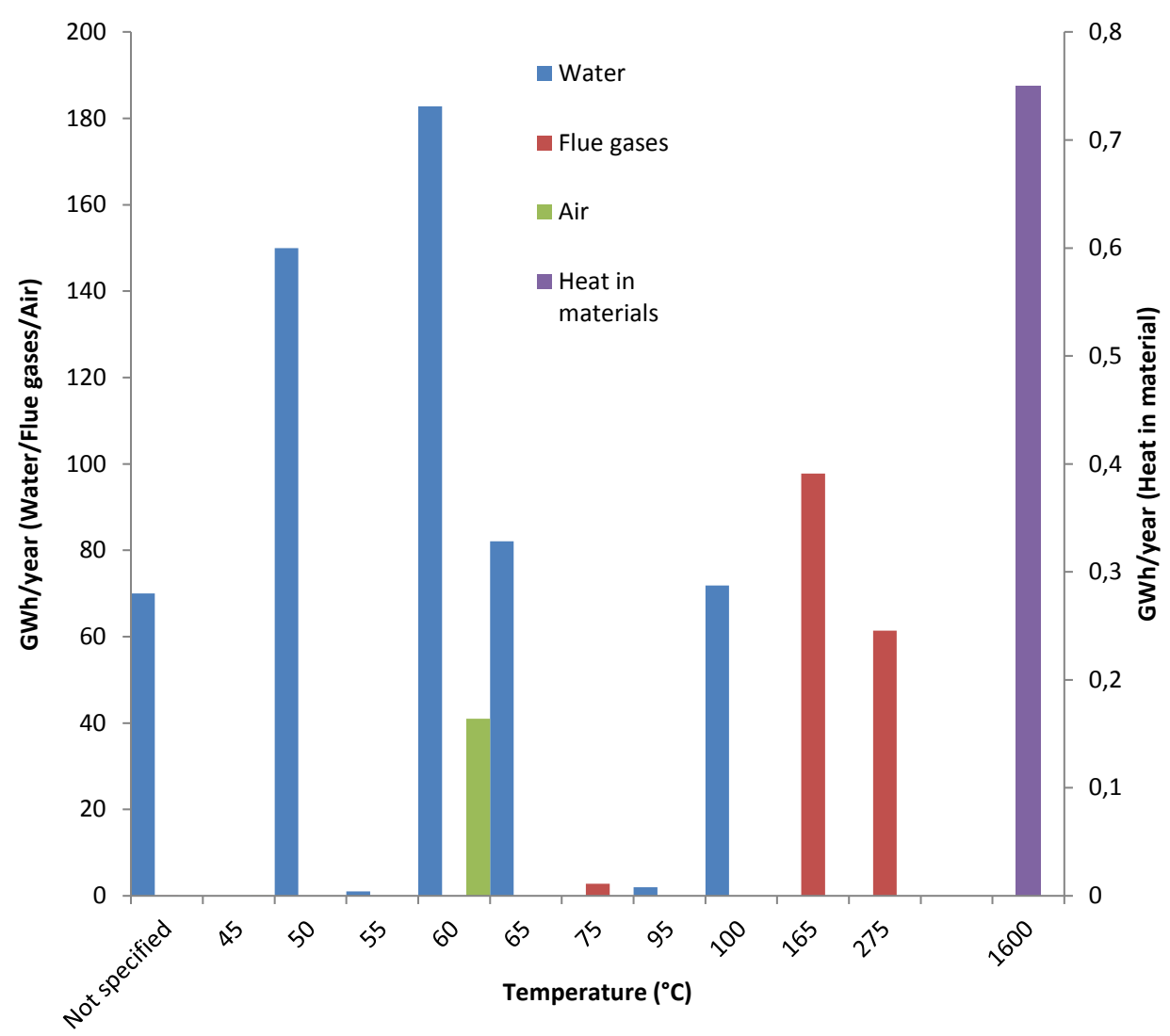

Figure 14. Untapped industrial excess heat potential ${ }^{13}$ in Gävleborg County in Sweden. Input to the calculations of potential was taken from a questionnaire. The response rate was $33 \%$ which means that the potential is probably underestimated.

As can be seen in Figure 14, the largest excess heat potential reported was carried in water, while the highest temperatures were found as heat carried in materials. Two options for recovery and external use of the industrial excess heat in Gävleborg County were considered in the study: heat delivery to DHS, and electricity production. The recovery output can be seen in Figure 15 . Heat sources with temperatures below $95^{\circ} \mathrm{C}$ were considered unfeasible for DH delivery. However, all heat sources with temperatures higher than $25^{\circ} \mathrm{C}$ were included in the calculations of electricity generation. Consequently, a larger amount of the excess heat was utilised in the case of electricity generation. However, the energy recovery output was larger for DH delivery, due to low conversion efficiencies of the electricity generation technologies. Heat pumps could be

\footnotetext{
${ }^{13}$ Some excess heat potentials are (or are almost) rounded to zero in the graph. These are: water $\left(55^{\circ} \mathrm{C}\right) 1 \mathrm{GWh} /$ year; water $\left(95^{\circ} \mathrm{C}\right) 2 \mathrm{GWh} /$ year; flue gases $\left(75^{\circ} \mathrm{C}\right) 2.8 \mathrm{GWh} /$ year; flue gases (not specified) $0.1 \mathrm{GWh} /$ year; and air $\left(45^{\circ} \mathrm{C}\right) 1 \mathrm{MWh} /$ year.
} 
used to increase temperatures of heat sources and consequently increase the amount of heat suitable for DH delivery, but that was not investigated in this thesis. Heat recovery for $\mathrm{DH}$ delivery leaves excess heat sources with temperatures below $95^{\circ} \mathrm{C}$ unutilised. These heat sources could be used to generate electricity in e.g. a PCM engine. Adding this electricity production to the DH delivery would give a recovery potential where all heat sources are utilised. This would give a total recovery potential of about $104 \mathrm{GWh} / \mathrm{year}$ which corresponds to $13 \%$ of the reported available industrial excess heat in Gävleborg County.

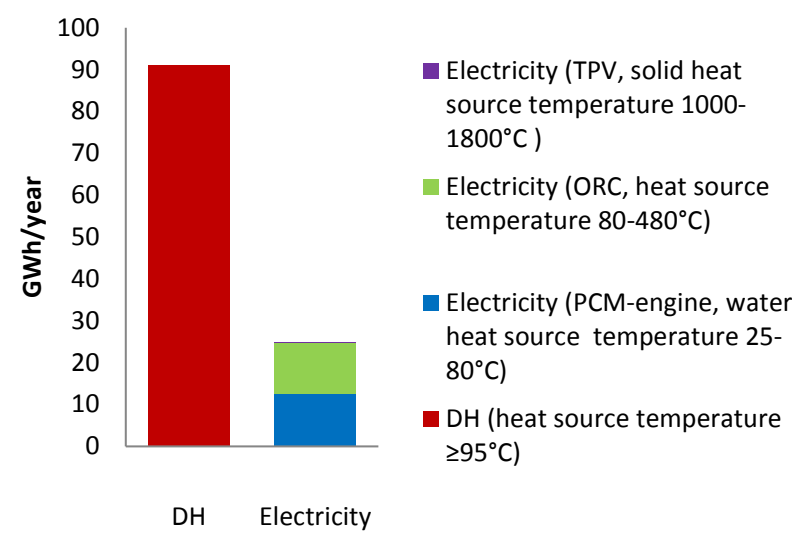

Figure 15. Recovery of industrial excess heat in Gävleborg County for use as DH or electricity generation.

\subsubsection{Economic evaluation of electricity production from low-temperature excess heat}

In Paper III, three technologies for the generation of electricity from low-temperature industrial excess heat were evaluated in more detail with regard to temperature range of heat source, capacity and economy. The technologies studied were TEG, ORC and PCM engine.

Because TEG, ORC and PCM engine use heat of different temperature ranges, there is potential for concurrent implementation of two or more of these. TEG based on bismuth telluride can utilise heat sources with temperatures from 150 to $300^{\circ} \mathrm{C}$, ORC designed for low-temperature heat sources can utilise heat sources with temperatures between 55 and $300^{\circ} \mathrm{C}$ and the PCM engine can generate electricity from heat sources with temperatures between 25 and $95^{\circ} \mathrm{C}$. Figure 16 shows the range of available sizes of the technologies and in what temperature range the technologies operate. 


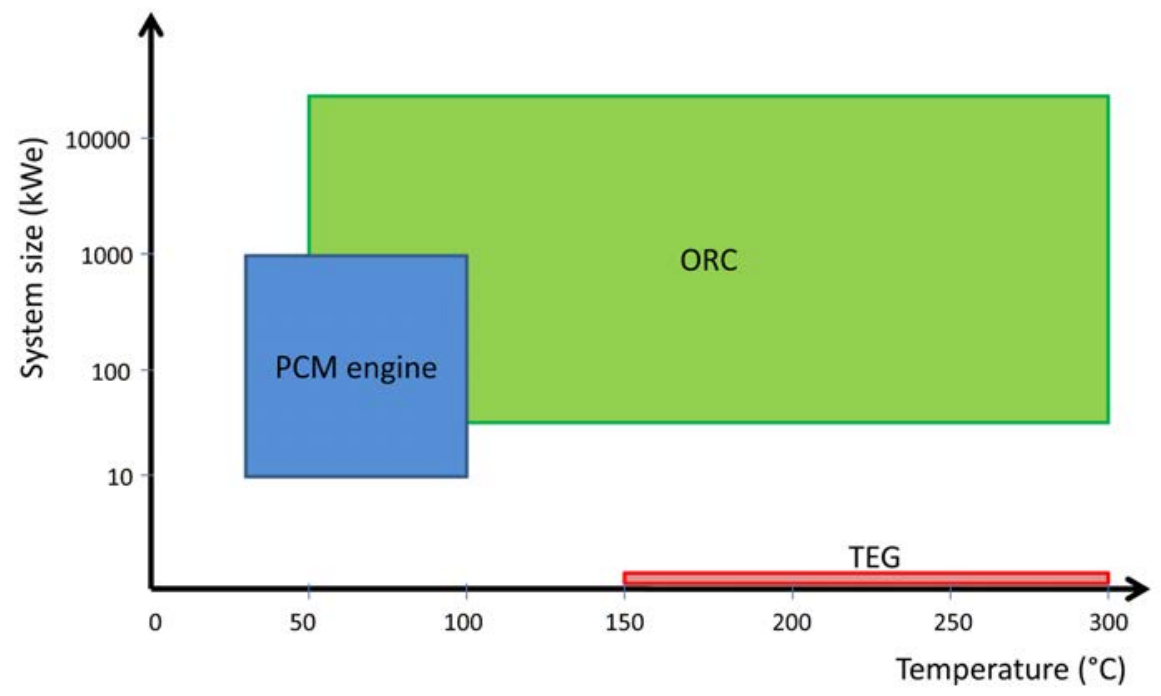

Figure 16. Available sizes of the electricity generation systems and temperature range of utilised heat source.

Results in Paper III show that with a discount rate of $10 \%$ and an economic lifetime of 20 years, TEG would not be feasible and profitable for large-scale low-temperature industrial heat recovery. However, the analysis indicated that heat recovery with ORC and PCM engine system could be profitable. As shown in Figure 17, ORC would be more profitable than PCM engine if the heat source temperature was higher than $80^{\circ} \mathrm{C}$ while the $\mathrm{PCM}$ engine system would be more cost-effective if the heat source was below $80^{\circ} \mathrm{C}$. However, profitability is site-specific and costs for auxiliary equipment, such as pipes and pumps for transportation of excess heat and cooling water, were not included in the calculations and has to be considered from case to case. 


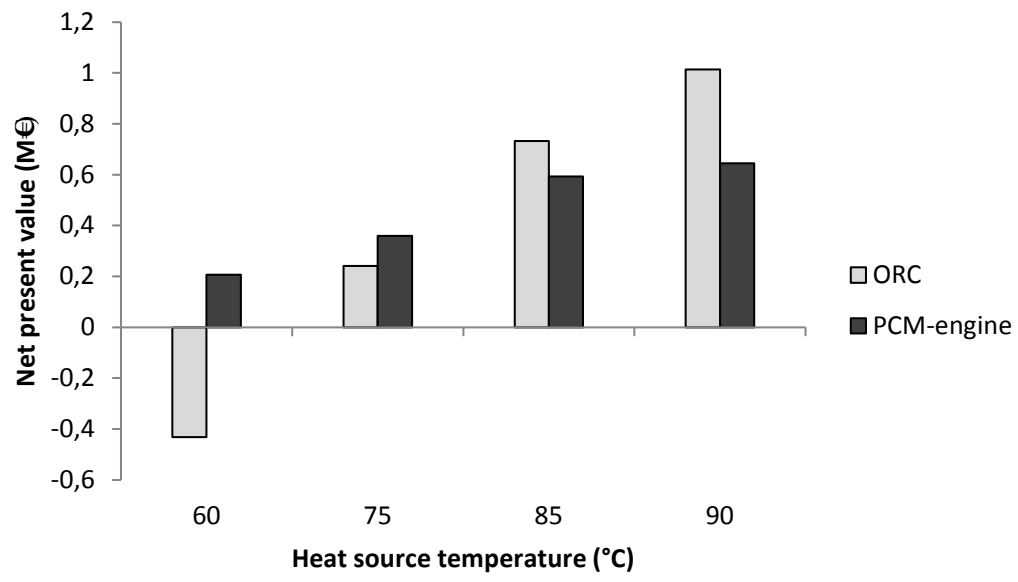

Figure 17. The net present value of an ORC system and a PCM engine system, operating $8000 \mathrm{~h} /$ year with a heat source flow rate of $350 \mathrm{~m}^{3} / \mathrm{h}$. For $4000 \mathrm{~h} /$ year, the cooling water has a temperature of $5^{\circ} \mathrm{C}$ and $4000 \mathrm{~h} /$ year the cooling water temperature is $20^{\circ} \mathrm{C}$. Electricity price was set at $61 € / \mathrm{MWh}$ during winter (6 months/year) and $45 € / \mathrm{MWh}$ during summer (6 months/year). Discount rate was $10 \%$ and economic lifetime was 20 years.

\subsection{2 $\mathrm{CO}_{2}$ emissions evaluation}

The results are based on the assumptions that wood fuel is a limited resource on the European market and increased or reduced electricity production affects marginal electricity production in Europe.

When industrial excess heat is delivered to a DHS the fuel demand in the DHS is reduced and this affects global $\mathrm{CO}_{2}$ emissions. If the DHS is based on biomass utilisation, biomass would then be available for the marginal user of biomass. Effects on global $\mathrm{CO}_{2}$ emissions depend on the type of heat production being replaced. Figure 18 shows reductions in global $\mathrm{CO}_{2}$ emissions if industrial excess heat in Gävleborg County ${ }^{14}$ would be recovered and used for $\mathrm{DH}$ delivery or electricity production. When the heat producer is a Swedish bio-HOB system, excess heat delivery would reduce global $\mathrm{CO}_{2}$ emissions in all scenarios studied. The reduction would be larger if the marginal user of wood fuel is a CCP plant with co-firing of wood fuel (EMS-3) than a producer of FT diesel (EMS-1 and EMS-2). When excess heat replaces heat production in a Swedish bio-CHP system, emissions would decrease when the marginal user of wood fuel is a CCP plant with cofiring of biomass (EMS-3), but when the marginal user of biomass is a producer of FT diesel (EMS-1 and EMS-2) emissions would increase. This can be explained by the fact that the bio-CHP system co-produces heat and electricity and when the demand for heat production is reduced, electricity production is also reduced. The reduced electricity production is compensated for with marginal electricity production. Fossil $\mathrm{CO}_{2}$ reductions

\footnotetext{
${ }^{14}$ The excess heat potential is based on a questionnaire with a response rate of $33 \%$.
} 
as a result of substituting fossil transportation fuel with FT diesel could not compensate for the increased emissions derived from increased marginal electricity production. If the excess heat would instead be used to produce electricity, the result would be reduced $\mathrm{CO}_{2}$ emissions in all scenarios studied. The reductions are larger if the marginal electricity producer is a CCP plant (EMS-1 and EMS-2) than if it is a NGCC plant (EMS-3).

When comparing the results of DH delivery and electricity production in the case of Gävleborg County, it is important to remember that in the calculations, all heat sources were utilised to produce electricity, but only heat sources with temperatures of $95^{\circ} \mathrm{C}$ or higher were used for DH delivery. However, an analysis of $\mathrm{CO}_{2}$ emissions reductions if only heat sources with temperatures of $95^{\circ} \mathrm{C}$ or higher would be recovered, shows that the emissions reductions would be larger when the heat is used for DH than for electricity generation in all scenarios except EMS-1 (bio-CHP) and EMS-2 (bio-CHP). This shows the advantages of CHP production in terms of effects on global $\mathrm{CO}_{2}$ emissions.

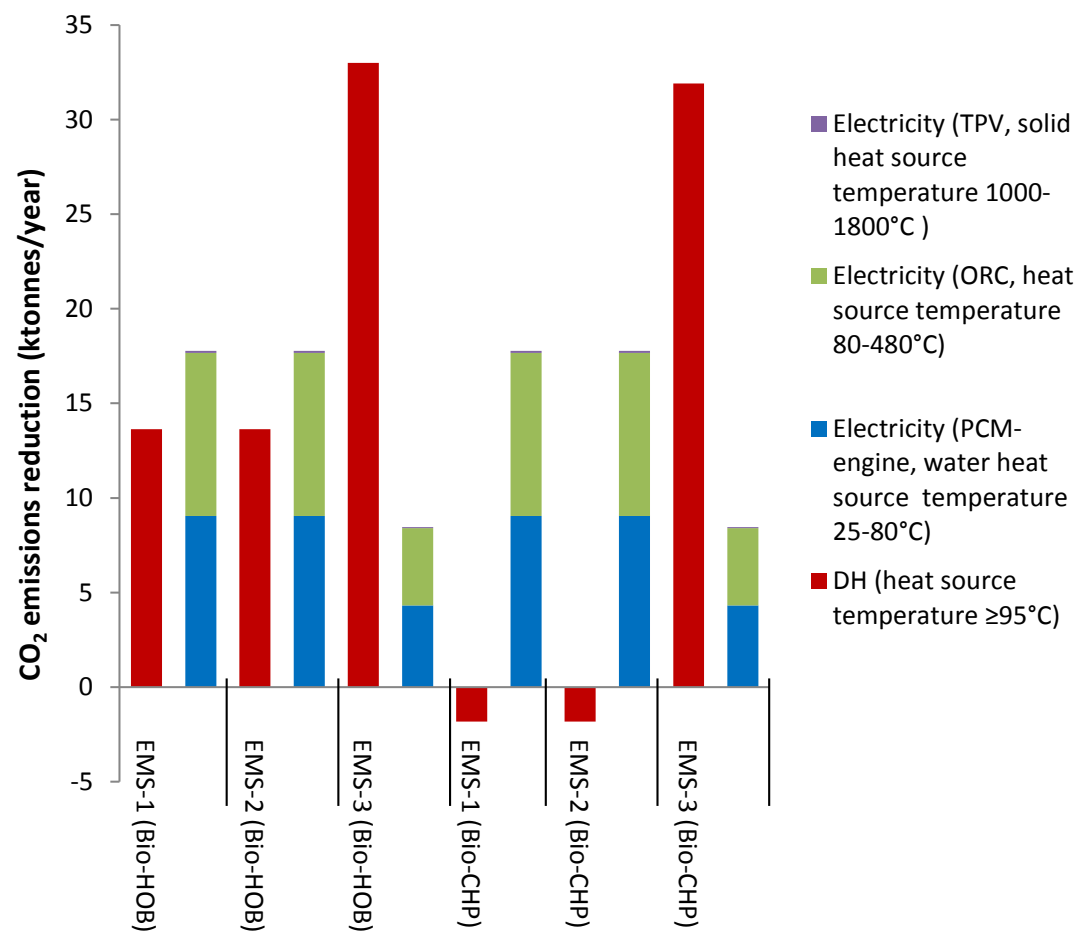

Figure 18. Reductions in global $\mathrm{CO}_{2}$ emissions if industrial excess heat in Gävleborg County is recovered and (1) delivered to a DHS or (2) used to generate electricity in a phase change material (PCM) engine, an organic Rankine cycle (ORC) and with thermophotovoltaics (TPV). Bio-HOB: DHS based on heat-only boilers fuelled with wood fuel. Bio-CHP: DHS based on wood fuel fuelled combined heat and power production. The excess heat potential is derived from a questionnaire and is probably underestimated. 


\subsection{Bio-syngas and bio-SNG as fuel in reheating furnaces}

LPG used as fuel in steel industry reheating furnaces can be substituted with syngas and SNG produced through gasification of wood fuel. Paper IV and V analyse these options. The introduction of bio-syngas or bio-SNG can be done by (1) partially substituting the LPG or (2) performing a full-scale substitution. In the first alternative, the biofuel could be mixed with LPG and the mixture could be used as fuel. Another solution for a partial fuel substitution would be to use LPG as fuel in the heating zone and bio-syngas in the soaking zone (temperature equilibration) in continuous furnaces. However, a full-scale fuel substitution would be the most viable solution, where furnaces and gas handling systems could be adjusted to one fuel. In this case natural gas or liquefied natural gas (LNG) (when there are no pipelines for natural gas) could be used as back-up fuel in case of productions disruption in the gasifier. Bio-SNG and fossil natural gas have in principle the same chemical gas property.

Before a fuel switch, modifications have to be done in furnaces and gas distribution systems, and an automatic control system which can compensate for fluctuations in fuel gas heating value has to be installed. As bio-syngas and bio-SNG have lower heating values than LPG, burners in the furnaces have to be replaced with burners designed for fuels with lower heating value and larger gas flows would be needed to satisfy the energy demand. Hence, a fuel gas distribution system with larger dimensions must be built. Moreover, the size of the steel plant's existing exhaust gas cleaning system can be a limiting factor as there would be larger volumes of exhaust gas. Another important consideration is that the fuel gas must not contain impurities, which can react with the steel and be deposited on the steel surface or damage furnace equipment. Such critical impurities are tar and sulphur, which means that the bio-syngas and the bio-SNG have to be cleaned from these elements before being used as fuel.

\subsubsection{Economic evaluation of bio-SNG as fuel in reheating furnaces}

In Paper V, the economy of a full-scale fuel switch from LPG to bio-SNG as fuel in reheating furnaces at Sandvik $A B$ in Sandviken was evaluated. The system cost for business as usual where the steel plant uses LPG as fuel was compared with the system cost where the steel plant has invested in a biomass gasification and methanation system and uses bio-SNG as fuel (see Equation 3 in Section 8.2). All of Sandvik's major LPGfuelled reheating furnaces were included in the analysis. These furnaces consumed approximately $80 \%$ of Sandvik's annual demand for LPG in reheating furnaces. Consistent EMS, generated by the ENPAC tool, were used to evaluate future economic potential for Sandvik in Sandviken to invest in a gasification and methanation system and to substitute LPG with bio-SNG as fuel in reheating furnaces.

Results from Paper V show that investments in a $45 \mathrm{MW}_{\text {th }}$ gasification and methanation system and a fuel substitution would not be profitable in any of the scenarios studied. Sensitivity analysis were performed where the discount rate was increased from $6 \%$ to $12 \%$; Sandvik's fuel demand was increased by $20 \%$ and the size of the gasifier was increased from $45 \mathrm{MW}_{\text {th }}$ to $55 \mathrm{MW}_{\text {th }}$; the period of excess heat delivery from the gasifier to the DHS was reduced from $8000 \mathrm{~h} /$ year to $5000 \mathrm{~h}$ /year; and the investment cost was reduced by $20 \%$ and $40 \%$ respectively. The sensitivity analysis shows (see Figure 19 ) that a reduction of the investment cost by at least $40 \%$ could make the fuel substitution 
profitable for Sandvik in Sandviken in EMS-1 and EMS-2. All other cases resulted in a negative NAP.

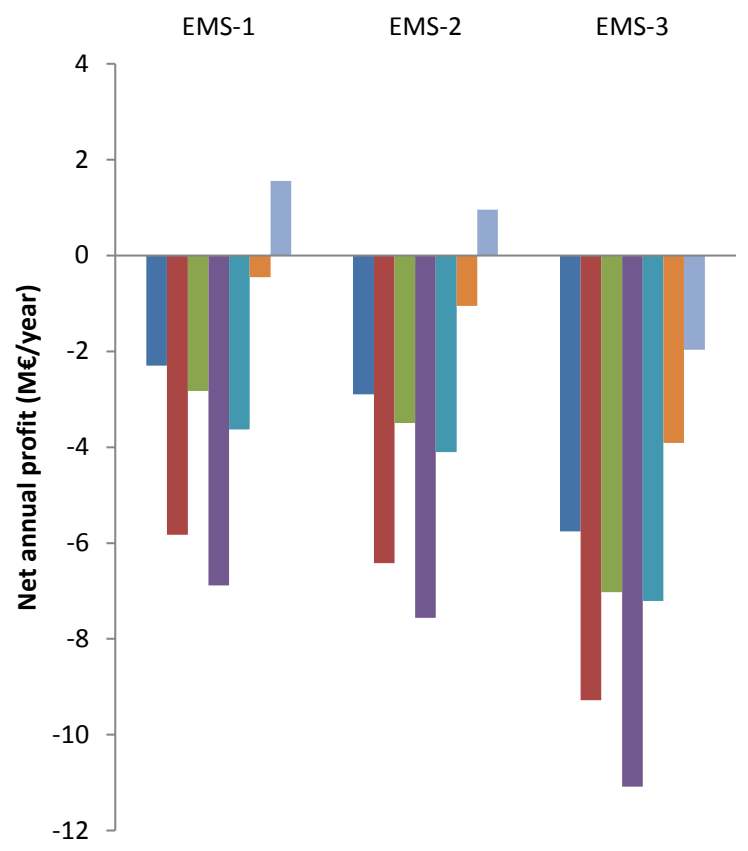

\author{
$45 \mathrm{MW}$ th gasifier, discount rate \\ $6 \%$ \\ $45 \mathrm{MW}$ th gasifier, discount rate \\ $12 \%$ \\ $55 \mathrm{MW}$ th gasifier, discount rate \\ $6 \%$ \\ $55 \mathrm{MW}$ th gasifier, discount rate \\ $12 \%$ \\ $45 \mathrm{MWth}$ gasifier, discount rate \\ 6\%, DH 5000h/year \\ $45 \mathrm{MWth}$ gasifier, discount rate \\ $6 \%, 20 \%$ reduced investment \\ cost \\ $45 \mathrm{MW}$ th gasifier, discount rate \\ $6 \%, 40 \%$ reduced investment \\ cost
}

Figure 19. Sensitivity analysis of net annual profit for investment in a biomass gasification and methanation system and substitution of LPG with bio-SNG as fuel in reheating furnaces at Sandvik $A B$ in Sandviken, The base case is investment in a $45 \mathrm{MW}_{\text {th }}$ gasifier, a discount rate of $6 \%$ and a discount period of 20 years. The discount rate is increased to $12 \%$ and/or the fuel demand is increased by $20 \%$ (55 $\mathrm{MW}_{\text {th }}$ gasifier). Additionally, the heat delivery to a DH system, based on bio$\mathrm{HOB}$, is reduced from $8000 \mathrm{~h} /$ year to $5000 \mathrm{~h} /$ year and the investment cost is reduced by $20 \%$ and $40 \%$ respectively.

To get a positive NAP and consequently an investment opportunity for site-specific investments, such as new burners in reheating furnaces, new gas distribution system and exhaust gas cleaning system, a policy support for renewable fuel or an investment grant for investing in a gasification and methanation system would be required. Table 15 presents the lowest levels of policy support required to achieve a positive NAP at Sandvik in Sandviken. 
Table 15. Lowest levels of policy support to achieve a positive net annual profit for production of bio-SNG and substitution of LPG with bio-SNG in reheating furnaces at Sandvik in Sandviken, Sweden.

\section{EMS-1 EMS-2 $\quad$ EMS-3}

Policy support for renewable fuel

$\left(€ / \mathrm{MWh}_{\text {bio-SNG }}\right)$

11

14

27

Policy support for renewable fuel

(\% of total bio-SNG production costs)

10

13

Investment grant (\% of total investment cost) 35

44

87

Figure 20 shows the costs for bio-SNG and LPG in the EMS investigated. It can be seen that the lowest production cost for bio-SNG occurred in EMS-2. This is the scenario with the lowest wood fuel price. It can also be noted that EMS-1 had the biggest difference between LPG price and biomass price. In conclusion, profitability is highly dependent on biomass and LPG prices. A low biomass price in relation to a high LPG price would favour substitution of LPG with bio-SNG. If the price of wood pellets was as specified in the scenarios, the LPG price would have to be at least 60-65 $€ / M W h$ higher than the price of wood pellets to get a positive NAP.

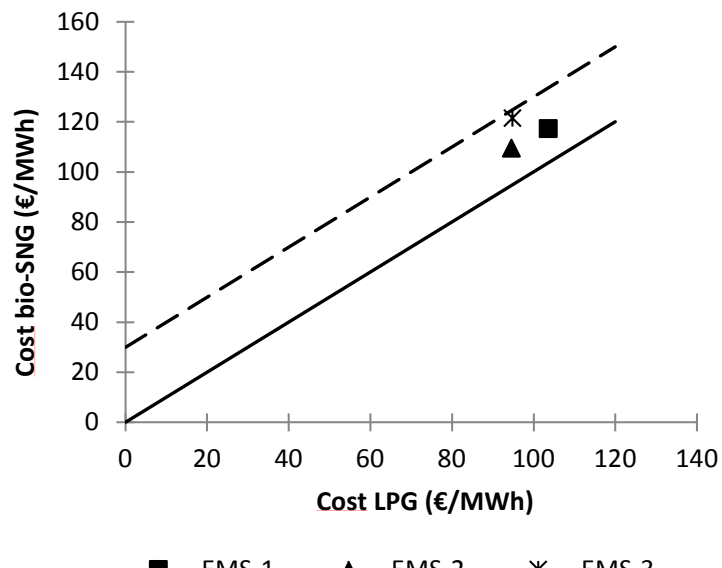

Figure 20. Cost for LPG (including cost for vaporisation of the gas and $\mathrm{CO}_{2}$ emission permits) and production cost for bio-SNG. Symbols above the solid diagonal line represent scenarios where the production cost for bio-SNG is higher than the cost for LPG. The dashed line shows the impact of a policy support of $30 € / \mathrm{MWh}_{\text {bio-sNG. }}$. 


\subsection{2 $\mathrm{CO}_{2}$ emissions evaluation}

Substitution of fossil fuels with biomass would result in reduced local fossil $\mathrm{CO}_{2}$ emissions. However, the effects on global $\mathrm{CO}_{2}$ emissions depend on the energy market. In Paper IV and Paper V, effects on global $\mathrm{CO}_{2}$ emission in case of Sandvik $\mathrm{AB}$ in Sandviken substituting LPG with bio-syngas or bio-SNG as fuel in reheating furnaces were studied. Three cases were studied: (1) no excess heat delivery from the gasifier to the DHS; (2) excess heat delivery from the gasifier to a bio-HOB system; and (3) excess heat delivery from the gasifier to a bio-CHP system. To facilitate comparison and evaluation in this thesis, the results from the two papers were recalculated with the same biofuel output and $\mathrm{CO}_{2}$ emissions factors (see Section 8.3). Figure 21 shows reductions in global $\mathrm{CO}_{2}$ emissions in case of a fuel switch. Under the assumptions that wood fuel is a limited resource on the European market and increased or reduced electricity production affects marginal electricity production in Europe, it would not be advantageous to substitute LPG with bio-syngas or bio-SNG in reheating furnaces if the marginal wood fuel user is a CCP plant with wood fuel co-firing (EMS-3). However, when the marginal wood fuel user is a producer of FT diesel (EMS-1 and EMS-2), a fuel switch at Sandvik in Sandviken would result in reduced global $\mathrm{CO}_{2}$ emissions; the largest reductions would be achieved if LPG is substituted with bio-syngas and excess heat from the gasifier is delivered to a bio-HOB system. In conclusion, from a $\mathrm{CO}_{2}$ emission perspective, the options for wood fuel utilisation considered in this thesis should be prioritised accordingly: (1) as fuel in CCP plants; (2) to produce bio-syngas or bio-SNG and substitute LPG as fuel in reheating furnaces; and (3) to produce FT diesel to the transport sector. Bio-SNG is produced from bio-syngas and the conversion efficiency from feedstock to final biofuel product is consequently lower for bio-SNG production compared to bio-syngas production. This explains why it would be more favourable to use bio-syngas than bio-SNG as fuel (see Figure 21). More excess heat is generated when producing bioSNG compared to bio-syngas. Therefore, the possibility to deliver heat to the DHS has a larger impact on the results for the case with bio-SNG than the case with bio-syngas.
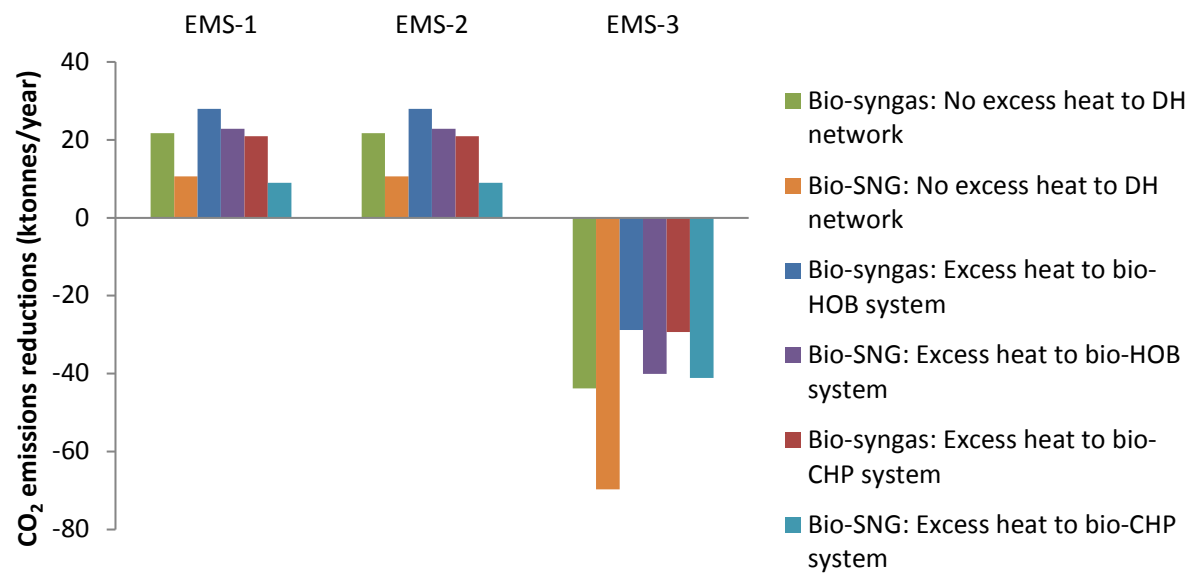

Figure 21. Reductions in global $\mathrm{CO}_{2}$ emissions when LPG is substituted with bio-syngas or bio-SNG as fuel in reheating furnaces at Sandvik AB in Sandviken. 
To show the impact of the perspective where biomass is seen as a limited resource and alternative use of wood fuel is considered, additional calculations have been done for the reverse perspective where biomass is regarded available for all potential users. Figure 22 shows a comparison of the two perspectives.

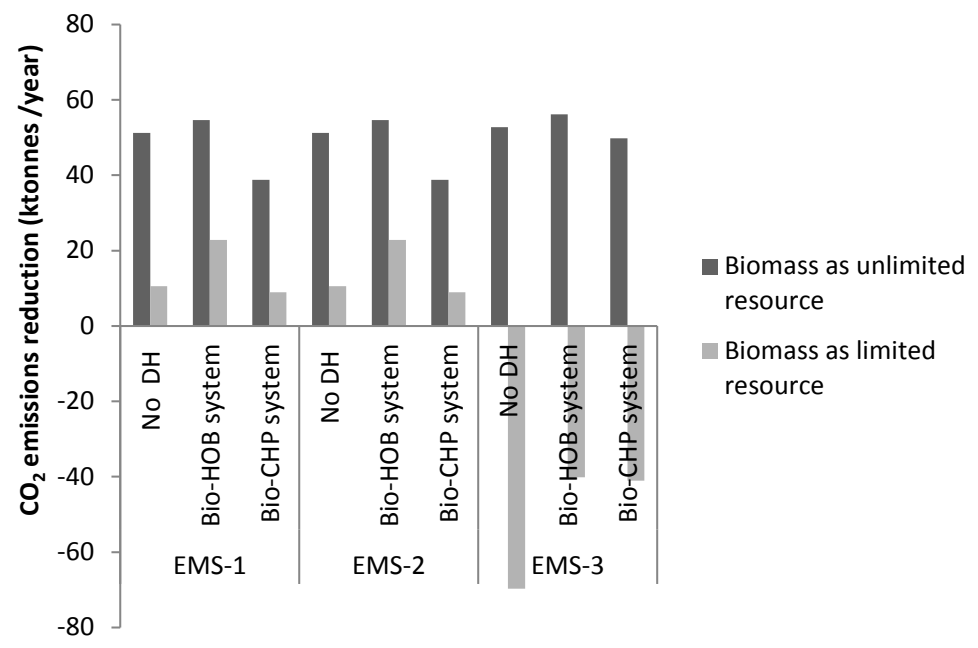

Figure 22. Reductions in global $\mathrm{CO}_{2}$ emissions when LPG is substituted with bioSNG as fuel in reheating furnaces at Sandvik AB in Sandviken. Two perspectives on biomass use are compared: 1) biomass is seen as an unlimited resource, and 2) biomass is seen as a limited resource and alternative use of wood fuel is considered. Positive values means reduced global $\mathrm{CO}_{2}$ emissions.

As can be seen in Figure 22, considering alternative use of wood fuel has a large impact on the evaluation of effects on global $\mathrm{CO}_{2}$ emissions. When biomass is seen as an unlimited resource, a fuel switch at Sandvik in Sandviken would result in reduced global $\mathrm{CO}_{2}$ emissions in all EMS studied. The largest differences between the two perspectives can be found in EMS-3, where build-margin technology for electricity is NGCC and CCP plants are regarded as the alternative users of wood fuel.

\subsection{Energy management}

In Paper VI, energy management practices at eleven iron and steel companies in Sweden were investigated. Energy managers at the steel mills were interviewed and the analysis focused on how they perceived their own and their companies' efforts to improve energy efficiency. The study identified measures the companies had implemented for improved energy efficiency. Results showed a range of measures which could be classified into five groups: maintenance, new equipment, optimisation of processes, energy recovery, and new working routines. However the energy managers interviewed had experienced 
barriers to improved energy efficiency, e.g. too long a payback period, measures not being profitable, lack of personnel, low willingness to invest due to recession, risk of production disruption, lack of time, territorialism with a fear of other people at the company interfering with the management, inability of suppliers, lack of personnel with higher education in the energy field, and people without commitment to energy issues. In general, the respondents considered lack of time a bigger barrier to improved energy efficiency than lack of access to capital. The reported barriers are similar to those found in previous research.

The study also analysed how energy management was organised at the companies. Only three out of the eleven companies had assigned a person to work full time with energy management, and the majority of the part-time energy managers were frustrated with not having enough time to work with the issues. This finding can be correlated to the fact that lack of time was seen as a bigger barrier than lack of access to capital. In general, the energy managers interviewed thought that they had support from senior management, which has previously been shown to be a criterion for successful energy management. Only three of the energy managers had the authority to make decisions about energysaving projects, but some companies had energy committees with decision-making power. The energy committees discussed potential projects and strategies and could support the energy manager with supplementary skills.

The companies' prioritising of energy efficiency practices was also analysed. A majority of the respondents thought their companies prioritised energy issues, and energy investments were usually prioritised as number three or four in budget planning. The respondents who said their companies did not prioritise energy efficiency were not directly subordinate to the CEO and felt that their proposals did not reach the CEO. Some energy managers thought that their companies sometimes put all the effort on improvements in production quantity and quality and neglected measures for improving energy efficiency.

Furthermore, the companies' activities with regard to engaging employees were investigated. Educating personnel is part of an effective energy management, but only half of the companies offered organised energy education to their employees. By increasing the employees' awareness, one company had decreased energy use. Two companies had positive experiences with the use of energy hosts, finding they motivated employees to become involved in improving energy efficiency. However, the majority of the respondents believed their companies could do better at engaging employees in improving energy efficiency. The study confirmed earlier research that recognised the importance of committed people in effective energy management practices. Another finding was that people without commitment to energy savings could be a barrier to improving energy efficiency, even opposing efforts to introduce efficient energy management.

Networking and its effects on the steel plants' energy management were investigated. Jernkontoret, the Swedish steel producers' association, administers networking among its members. At network meetings, energy managers could exchange information and find ideas and inspiration for energy-saving projects. The interviewed energy managers especially appreciated meetings with site visits where "good examples" of implemented measures were presented. However, lack of time often made inspiration fade and 
prevented the respondents from implementing ideas. Networking with other sectors was also seen as important.

Based on the results of the interview study, the following recommendations for a successful energy management are given:

- Employ a full-time energy manager.

- Employ more energy engineers with a holistic view on the company's energy use so that interdependencies between different systems are taken into account.

- Appoint an energy committee and let the energy manager be the convener. The committee should have representatives from all departments. Give the committee a mandate to decide on measures for improving energy efficiency.

- Prioritise initiation and completion of pre-studies of potential energy-saving projects. A well prepared pre-study provides a good basis for a robust investment decision.

- Energy aspects should be incorporated in every investment decision. The energy manager should, when needed, be consulted before the decision.

- The company should strive for a culture where every employee is working energyefficiently and seeks measures for improvement. This can be achieved through training, continuous information and visualization of energy use and presentation of good examples. Good role models and interested and committed employees should be encouraged. Each energy-saving measures should be promoted, even if they seem small related to the company's total energy use. This could introduce a common practice of energy-efficient behaviour.

- Networking between energy managers from different companies should be encouraged. Besides the energy managers, employees in decision-making positions should attend organised meetings, such as Jernkontoret's energy network meetings, to be inspired and find new energy visions. 
Maria Johansson 


\section{Discussion}

This chapter discusses the results of this thesis.

In this thesis, energy efficiency measures and fuel substitution in the iron and steel industry were studied. These are two opportunities for the steel industry to reduce global $\mathrm{CO}_{2}$ emission and one approach does not exclude the other.

Excess heat can be carried in different media such as water, air, exhaust gas and hot material. The challenge is to recover the heat and transfer it to a heat sink or convert it to other energy forms without complex and expensive installations and unnecessary energy losses. The excess heat that requires least effort and is cheapest to recover would be the first to be utilised. It is important that any energy recovery equipment does not interfere with the steel production in a negative way. For example, equipment for heat recovery from hot material must not hinder overhead cranes. On the other hand heat recovery from hot material could offer a means to control the cooling rate of the material. One barrier for heat recovery could be that the heat demand is lower than the available excess heat. In the case of heat delivery to DHS, the industry may be located in a municipality with a low heat demand. The heat could be transferred to another municipality if the DHS are connected, but in reality this is quite uncommon. Moreover, in Sweden, subsidies for renewable electricity production have resulted in that many municipalities decided to invest in biomass fuelled CHP plants to produce electricity and heat to the DHS. As a consequence, they rejected import of excess heat from industry. They calculated a better profitability with a biomass fuelled CHP plant compared to the utilisation of industrial excess heat. In the example of Gävleborg County, studied in Paper II, the untapped industrial excess heat recovery potential for DH delivery was estimated at $91 \mathrm{GWh} /$ year. This potential is probably underestimated as not all firms completed the questionnaire and the firms which completed the questionnaire most likely only reported heat flows which they had quantified. The total heat supply in the DHS in Gävleborg County was $2 \mathrm{TWh} /$ year (Statistics Sweden, 2013) and about 11\% (Swedish District Heating Association, 2010) of this supply originated from industrial excess heat. Therefore, there should be potentials for additional supply of industrial excess heat. However, one concern is the distance between the heat source and the heat sink. One must keep in mind that the excess heat potential presented in this thesis was not generated at one location, but the industries were located all over Gävleborg County. Investment in heat distribution networks and distribution costs must be considered and evaluated in comparison to the heat generation costs. Investment cost for pipeline construction depends on where the pipeline would be situated, e.g. inner city areas have a higher construction cost than outer city areas (Frederiksen and Werner, 2013; Swedish District Heating Association, 2007). 
In the case of electricity generation from excess heat it would probably be economically unfeasible for a steel plant to invest in more than one electricity generation system and the system with best performance for the specific site should be chosen. Electricity generation from heat could be an alternative if for some reason the heat demand is low or the excess heat is not suitable for $\mathrm{DH}$. Even if conversion efficiencies of the electricity generating systems are low, investments could be profitable as the heat is "free of charge". However, the economy depends not only on investment costs for the electricity generating equipment but also on distribution costs for excess heat flows and cooling water. Future electricity prices also determine if the investment would be profitable. It would be hard to predict the future, but in a functioning deregulated European electricity market, price differences in electricity between countries would be evened out. Policy instruments that promote electricity production from industrial excess heat could provide incentives for steel plants to invest in electricity generation technologies. A system similar to the Swedish system of green certificates for renewable electricity production could be applied. However, restrictions have to be made so that only electricity production from excess heat from thermodynamically optimised industrial processes would be granted such certificates.

The development of fossil fuel prices is uncertain. The increased production of shale gas in the USA has resulted in lower prices for natural gas and oil than previously predicted. IEA (2012b) forecast that shale gas production in the USA will increase from 200 billion $\mathrm{m}^{3}$ in 2011 to 450 billion $\mathrm{m}^{3}$ in 2040. To consider uncertainties in future price trends, different future energy markets with different price levels, marginal electricity production technologies and marginal biomass users could be studied. In this thesis, the ENPAC tool has been used to generate possible future energy markets. The ENPAC tool generates consistent end-user prices on fuels as well as factors for $\mathrm{CO}_{2}$ emissions. Moreover, the fact that scenarios from World Energy Outlook (IEA, 2011) were used as input to the tool makes the analysis even more consistent.

Fuel substitution in the iron and steel industry could result in substantial $\mathrm{CO}_{2}$ mitigation. However, as there would be competition for the biomass resource in the future, alternative use of biomass has to be considered. Co-firing wood fuel with coal in CCP plants have been shown to significantly reduce GHG emissions (Loeffler and Anderson, 2014), and when only considering $\mathrm{CO}_{2}$ emissions, it would be better to substitute coal in a CCP plant than to substitute fossil fuels in the iron and steel industry. In this thesis, other environmental impacts such as air acidification and water eutrophication were not analysed. However, Muench and Guenther (2013) performed a review of bioenergy LCAs. They did a quantitative analysis of the environmental impact (global warming, acidification and eutrophication) of electricity and heat generation from biomass and concluded that differences in results depended on methodological choices and system boundaries.

It may be controversial to say that delivering industrial excess heat to DHS would result in increased global $\mathrm{CO}_{2}$ emissions. However, under the assumptions that biomass is a limited resource on the European market and increased or reduced electricity production affects marginal electricity production in Europe this could be true. Results in this thesis show that if heat production in bio-CHP plants is replaced with industrial excess heat, global $\mathrm{CO}_{2}$ emissions would increase when the marginal electricity producer is a CCP 
plant and the marginal user of woof fuel is a producer of FT diesel to the transport sector. Similar results were presented by Ivner and Helgstrand (2011) who performed an LCA of replacing conventional DH production with industrial excess heat. They analysed GHGs, acidifying gases and eutrophic substances. They found that under the premises defined in their study it would always be beneficial to replace heat produced in HOB. In regard to heat systems with DH production in CHP plants, their results depended on how the system boundaries for electricity production were defined; if reduced electricity production would be replaced by European electricity mix, import of industrial excess heat to the DH system would result in adverse environmental effects. It could be argued that these results imply that industrial excess heat should not be recovered. However, using the excess heat in applications other than replacing heat production in bio-CHP plants would be advantageous for the environment. Moreover, new bio-CHP plants should perhaps not be built in municipalities where industrial excess heat is available to cover the municipality's heat demand, but should be located in other places with heat demand.

Without policy support for renewable energy in industrial processes, it would not be economically feasible to convert from LPG to bio-SNG in steel industry reheating furnaces. In this thesis, detailed economic analysis of bio-syngas as substitute was not performed. However, production cost for bio-syngas is lower compared to bio-SNG as the methanation unit is a large investment. Large-scale biomass gasification is not a commercial technology, but when commercialized the investments costs may probably be lower. An important aspect to consider is the construction area of a gasification plant. There has to be available land for the plant to be built on. Furthermore, bio-syngas has lower heating value than bio-SNG and hence larger gas flows would be required to fulfil the energy demand. Today, integrated steel plants fire reheating furnaces with COG, which has a heating value of $4.7 \mathrm{kWh} / \mathrm{Nm}^{3}$ (16.9 MJ/ $\mathrm{Nm}^{3}$ ) (Jernkontoret, 2007). This heating value is in the range of heating values for bio-syngas produced with steam or oxygen as gasifying agent. The possibility of using solid biomass, in the form of wood powder, as fuel in reheating furnaces has been experimentally studied (Niska et al., 2013). The results showed that wood pellets ash contained alkali compounds that could react with silica in furnace refractories and form a glassy phase on furnace bricks. Therefore, it was recommended to gasify the solid biomass into syngas and fire the reheating furnaces with cleaned bio-syngas.

Energy management is important for achieving improvements in energy efficiency. The results from the interview study in this thesis reflect the current situation experienced by the respondents at the steel plants studied. Even if the results cannot be generalized to a larger sample, they provide knowledge of how the work with improved energy efficiency at Swedish steel works proceed and can be used to develop recommendations for successful energy management. 


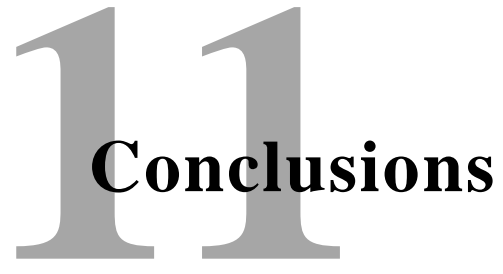

In this chapter conclusions from the research in the appended papers are drawn. Conclusions are given for each of the research questions posed.

\section{Which technologies could be used to recover excess energy from the steel industry?}

There are more energy recovery options for integrated steel plants compared to scrapbased steel plants. This is reasonable as integrated steelmaking includes the energyintensive production of iron from iron ore, in which energy-rich process gases are generated. These process gases could be used as fuel in CHP plants and COG could be reformed to syngas. Excess heat from the iron and steel industry, could be used in-house at the steel mill or exported and used externally. The two main utilisation options for the recovered heat are heating purposes and electricity generation. When the excess heat is used for space heating, the heat could be used locally by heat exchanging with incoming ventilation air or distributed in a local heat distribution system. It could also be distributed by a municipal DHS and used externally. There are several technologies that could be used to generate electricity from excess heat; each technology operates within a specified temperature range of the heat source. Power cycles, such as Rankine cycle, ORC, Kalina cycle, PCM engine and Stirling cycle, convert heat into mechanical energy and the mechanical energy is converted into electricity. Solid state energy converters are e.g. TPV, which produces electricity from heat radiation in PV cells, and TEG, which produces electricity from heat by the Seebeck effect. One drawback for electricity generation from low-temperature heat is the low electricity conversion efficiencies. However, the higher the heat source temperature (within the operating temperature range of the conversion technology) the higher the electricity output. Industrial firms in Gävleborg County reported an untapped excess heat potential of 0.8 TWh in 2012 . Analysis in this thesis showed that about $90 \mathrm{GWh}$ of this heat could be recovered as DH and if the heat instead was used to generate electricity by TPV, ORC, and PCM engine, 25 GWh electricity could be produced. In conclusion, the recovery output would be more than three times higher if the excess heat is used in a DHS than if generating electricity.

\section{Could electricity generation from low-temperature excess heat be profitable?}

Economic analysis of electricity production from low-temperature excess heat showed that, at current price levels and technical maturity, it could be profitable to convert the heat into electricity in an ORC or a PCM engine, but not in a TEG. The PCM engine would be more profitable than the ORC when the heat source temperature is lower than $80^{\circ} \mathrm{C}$. However, the analysis did not include site-specific costs for piping and pumping 
excess heat and cooling water. Investment opportunity for such equipment was, for the specific cases studied in this thesis, estimated at 14,000-114,000 €/year, depending on the technology and the temperature of the heat source. The ORC is the most established and proven technology and the choice of working medium determines the efficiency of the installation. Increased market penetration of the electricity generation technologies and development of new TE materials could reduce investment costs and increase profitability. In case of rising energy prices the economic situation for investment in electricity generation technologies from excess heat would improve. Moreover, introduction of a policy instrument similar to the green certificates for renewable electricity production could be applied for electricity production from industrial excess heat (from thermodynamically optimised industrial processes). This would create economic incentives for steel plants to invest in such electricity production technology.

\section{Would it be technically and economically feasible for a steel plant to substitute fossil fuels with biomass?}

For the systems studied in this thesis, it can be concluded that it would be technically feasible to convert from fossil fuels to biomass. Today, many integrated steel plants have reduced the coke demand in the BF by injecting coal powder. It would be possible to substitute this injection coal with pulverised charcoal without any major adjustments in the BF process. Another fuel substitution option is substitution of LPG with bio-syngas or bio-SNG as fuel in reheating furnaces. This option requires some modifications at the steel plant, e.g. burners designed for low-calorific gases, gas distribution systems with larger dimensions and exhaust gas cleaning systems dimensioned for larger gas flows. In the case of a substitution to bio-SNG, steel plants currently using natural gas as fuel do not have to do these modifications. Though technically feasible, it can be concluded that it would not be economically feasible for Sandvik AB in Sandviken to produce bio-SNG and to substitute LPG with bio-SNG in reheating furnaces. For the fuel substitution to be profitable, investment grants or production support for renewable fuel have to be implemented. Another consideration is the large amounts of biomass required to substitute the fossil fuels and logistics for biomass handling.

\section{How would recovery and utilisation of excess heat, and a fuel substitution affect global $\mathrm{CO}_{2}$ emissions?}

It can be concluded that the development of the energy market plays a vital role for the outcome of the analysis of effects on global $\mathrm{CO}_{2}$ emissions. Table 16 presents the results for the energy markets studied in this thesis. Electricity production from industrial excess heat would reduce global $\mathrm{CO}_{2}$ emission. However, in the case of industrial excess heat delivered to the DHS the effects on global $\mathrm{CO}_{2}$ emissions would depend on which heat production it replaces. Large DHS are more likely to have CHP production than small systems. Excess heat delivered to large DHS with bio-CHP plants would make biomass available for other users, but at the same time reduce renewable electricity production. This emphasises the value of co-producing heat and electricity, especially when the marginal producer of electricity is a CCP plant. In small DHS, with a large share of heat production in bio-HOBs, delivery of industrial excess heat would make wood fuel available for the marginal wood fuel user, but not significantly affect electricity production. Hence, the result would be reduced emissions in all scenarios. 
The effects of a fuel substitution from LPG to bio-syngas or bio-SNG depend on who is the alternative user of wood fuel. Substitution of LPG with bio-syngas or bio-SNG would reduce global $\mathrm{CO}_{2}$ emissions when the marginal user is a producer of FT diesel to the transport sector, but the emissions would increase if the marginal user of wood fuel is a CCP plant. In conclusion, wood fuel utilisation should be prioritised in the following order: (1) in CCP plants; (2) to be converted to bio-syngas and replace LPG in steel industry; (3) to be converted to bio-SNG and replace LPG in the steel industry; and (4) to be converted to FT diesel and replace fossil fuels in the transport sector.

Table 16. The table shows how fuel substitution and excess heat recovery would affect global $\mathrm{CO}_{2}$ emissions in different future energy market scenarios. $\downarrow$ reduced global $\mathrm{CO}_{2}$ emissions, $\uparrow$ increased global $\mathrm{CO}_{2}$ emissions. $\mathrm{BM}=$ marginal user of wood fuel, El=build-margin electricity production, $\mathrm{DH}=$ heat production to the DHS

\begin{tabular}{l|lll}
\hline & $\begin{array}{l}\text { Fuel } \\
\text { substitution }\end{array}$ & $\begin{array}{l}\text { Excess heat } \\
\text { to DHS }\end{array}$ & $\begin{array}{l}\text { Electricity } \\
\text { production } \\
\text { from excess } \\
\text { heat }\end{array}$ \\
& & $\downarrow$ & $\downarrow$ \\
BM: FT diesel production & $\downarrow$ & $\downarrow$ & $\downarrow$ \\
El: CCP plant & & & \\
DH: bio-HOB & & $\uparrow$ & $\downarrow$ \\
BM: FT diesel production & $\downarrow$ & & $\downarrow$ \\
El: CCP plant & & & \\
DH: bio-CHP & & & $\downarrow$ \\
BM: CCP plant & & & \\
El: NGCC & & & \\
DH: bio-HOB & $\uparrow$ & & \\
BM: CCP plant & & & \\
El: NGCC & & & \\
DH: bio-CHP & & & \\
\hline
\end{tabular}

5. Why are energy efficiency measures implemented or why are they not implemented in the Swedish iron and steel industry?

Results from the interviews showed that measures for improved energy efficiency often were implemented because of an employee with a commitment for energy savings. In several of these cases this employee was the energy manager interviewed, but it could also be a person that did not have these assignments in his/her job description. This finding shows that people with real ambition and commitment for energy savings are an important resource for the company and they should be valued as such. By identifying them, listening to their ideas and even assigning them authority to start projects for improved energy efficiency the company could achieve more effective energy management. By recognizing energy as important and making employees aware of the energy issue, one of the companies in the study had recorded a decrease in energy use. Increasing the awareness of employees and introducing a culture of energy efficiency could help to reduce behavioural barriers. Networking among energy managers at 
Swedish steel plants was seen as valuable for their profession and they especially appreciated meetings with site visits where "good examples” were presented.

The energy managers interviewed expressed that barriers ${ }^{15}$ to improving energy efficiency at their companies were too long a payback period, measures not being profitable, lack of personnel, low willingness to invest due to recession, risk of production disruption, lack of time, fear of other people interfering with the management, suppliers that lacked larger system perspectives, lack of personnel with higher education, and people without commitment to energy issues. The energy managers working full-time with energy issues did not experience lack of time as a barrier, but the energy managers working part-time with energy issues often found that lack of time, rather than lack of financing, prevented them from successful energy management. It is therefore recommended that steel companies employ a full-time energy manager and/or more personnel assigned to work with energy issues. However, it was expressed during the interviews that there was a lack of personnel with higher education in the energy field, who could see the energy system from a larger system perspective. This finding implies that universities should educate more energy engineers with a comprehensive view on energy and that steel companies, suppliers of equipment and energy consultancies should employ such engineers.

In conclusion, Swedish steel companies regard improved energy efficiency as important, but have much work to do in this area. For example, large amounts of excess heat are not recovered and more efforts could be put into engaging employees to introduce a culture of energy efficiency at the company. Lack of time seems to be a major barrier for efficient energy management as well as for productive networking.

\footnotetext{
${ }^{15}$ In this study, barriers were not limited to barriers to cost-effective energy efficiency measures.
} 


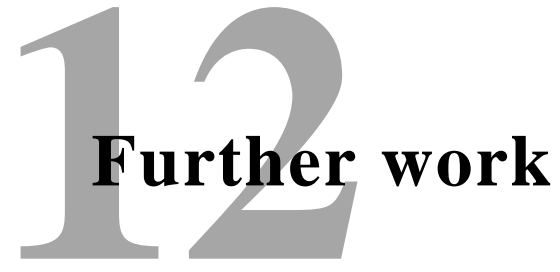

During the work with this thesis, additional ideas were raised that would be interesting to study. The suggestions for further work would provide additional information which could guide decision-makers in steel industry and policy-makers to take action to improve the steel industry's competiveness and to reduce anthropogenic global $\mathrm{CO}_{2}$ emissions.

It would be of interest to perform a detailed techno-economic analysis of bio-syngas as fuel in reheating furnaces. India, with its large coal deposits, has built several coal gasifiers at steel mills and substituted oil in the reheating furnaces with syngas. This syngas is of fossil origin, but proves the feasibility of using the low calorific syngas as fuel. Further studies could examine a suitable configuration of a biomass gasifier and how the gasifier could be integrated with the steel plant. Under what conditions could a fuel substitution to bio-syngas be profitable? The questions could be analysed as a case study and compared to the results from the techno-economic analysis of bio-SNG as a fuel substitute.

Another interesting issue to study is heat recovery from excess heat sources such as EAF, continuous casting and slag. Heat recovery from slag would have a large potential and there would be no risk of affecting the quality of a steel product. In the case of heat recovery from steel products, the possibility of controlling the cooling rate of hot steel would enable production of specified steel qualities. Repeated heating and cooling operations is one way of attaining steel with desired qualities and to install equipment that controls the heat loss and at the same time recovers the heat would be very interesting.

One important issue to analyse is what policy measures would be required to realize a fuel substitution in the iron and steel industry. Such a study could include interviews with policy makers and steel industry board of directors. The interviews could be supplemented with mathematical modelling of a steel plant with the possibility to integrate a biomass gasifier or to import bio-SNG from external producers. Optimization of the model, with the objective function to minimize total system costs, would give the most cost-effective solution under specified boundaries. Introducing policy instruments into the model and varying them would enable a study of required policy instruments for fuel substitution.

The study of energy management, where energy managers were interviewed, could be complemented with additional interviews with employees at other positions at the steel companies, from CEOs to operators. It would be interesting to analyse if the interviewees' experiences and opinions differ depending on job assignments. Additional interviews would give a more comprehensive view of the subject studied. 
Jernkontoret's Energy Research Programme was completed in 2011, after five years of research. The objective of the research programme was to investigate options to reduce the steel industry's total energy use, the use of fossil fuels, and $\mathrm{CO}_{2}$ emissions. An interesting future study could be to investigate if the options identified in the research programme are implemented at Swedish steel plants. Have the research results reached the management of Swedish steel companies? What was the reason for choosing a specific measure for implementation and what was the reason for rejecting another? How could enhanced implementation of the options identified in the research programme be realized? 


\section{References}

AISI. (2013) American iron and steel institute. Available at: www.steel.org/en/Making\%20Steel/Research\%20and\%20Development.aspx. (accessed 14 May, 2013).

Ammar Y, Joyce S, Norman R, et al. (2012) Low grade thermal energy sources and uses from the process industry in the UK. Applied Energy 89: 3-20.

Apeaning RW and Thollander P. (2013) Barriers to and driving forces for industrial energy efficiency improvements in African industries - a case study of Ghana's largest industrial area. Journal of Cleaner Production 53: 204-213.

Arvidsson M, Heyne S, Morandin M, et al. (2012) Integration opportunities for Substitute Natural Gas (SNG) production in an industrial process plant. Chemical Engineering Transactions 29: 331-336.

Asp B, Wiklund M and Dahl D. (2008) Use of the steel industry's residual energies for power generation - an efficient resource utilization for electricity generation [Användning av stålindustrins restenergier för elproduktion - Ett effektivt resursutnyttjande för elproduktion]. Report No JK98400, Jernkontorets forskning D826, Stockholm, Sweden: Jernkontoret. Available at:

www.jernkontoret.se/ladda_hem_och_bestall/publikationer/stalforskning/rapporte r/d_826.pdf. [in Swedish]

Axelsson E and Harvey S. (2010) Scenarios for assessing profitability and carbon balances of energy investments in industry - Pathways to sustainable European energy systems. AGS Pathways report 2010:EU1, Gothenburg: AGS, The alliance for global sustainability.

Axelsson E, Harvey S and Berntsson T. (2009) A tool for creating energy market scenarios for evaluation of investments in energy intensive industry. Energy 34: 2069-2074.

Axelsson E and Pettersson K. (2014) Energy price and Carbon Balances Scenarios tool (ENPAC) - a summary of recent updates. Chalmers University of Technology, Gothenburg, Sweden. Available at:

https://publications.lib.chalmers.se/publication/194812-energy-price-and-carbonbalances-scenarios-tool-enpac-a-summary-of-recent-updates.

Bacovsky D, Dallos M and Wörgetter M. (2010) Status of 2nd Generation Biofuels Demonstration Facilities in June 2010: A report to IEA bioenergy Task 39. Report T39-P1b: Available at: http://www.isesitalia.it/docfrm/areasoci/documenti/Status\%20of\%202nd\%20gen \%20Biofuel\%20Demonstration\%20Facilities\%20\%20IEA\%20Bioenergy\%20Task\%2039.pdf.

Bacovsky D, Ludwiczek N, Ognissanto M, et al. (2013) Status of Advanced Biofuels Demonstration Facilities in 2012: A report to IEA Bioenergy Task 39 T39-P1b: 
Available at:

http://demoplants.bioenergy2020.eu/files/Demoplants_Report_Final.pdf.

Barati M, Esfahani S and Utigard TA. (2011) Energy recovery from high temperature slags. Energy 36: 5440-5449.

Basu P. (2010) Biomass gasification and pyrolysis: practical design and theory, Norwood: Burlington, Mass. : Academic Press.

Bauer T, Forbes I and Pearsall N. (2004) The potential of thermophotovoltaic heat recovery for the UK industry. International Journal of Ambient Energy 25: 19-25.

Bendig M, Maréchal F and Favrat D. (2013) Defining "Waste Heat” for industrial processes. Applied Thermal Engineering 61: 134-142.

Birat J-P. (2010) Global Technology Roadmap for CCS in Industry: Steel Sectoral Report. Version 5 of 09/09/2010: ArcelorMittal, United Nations Industrial Development Organization (UNIDO). Available at: http://cdn.globalccsinstitute.com/sites/default/files/publications/15671/globaltechnology-roadmap-ccs-industry-steel-sectoral-report.pdf.

Birat J-P, Borlée J, Lavelaine H, et al. (2012) ULCOS Programme: an update in 2012. SCANMET IV - 4th International Conference on Process Development in Iron and Steelmaking.

Boerrigter H and Rauch R. (2005) Syngas production and utilisation. In: Knoef HAM (ed) Handbook: Biomass gasification. The Netherlands: BTG biomass technology group.

Brau JF, Morandin M and Berntsson T. (2012) Integration of a biomass-to-hydrogen process in an oil refinery. Chemical Engineering Transactions 29: 1087-1092.

Brau JF, Morandin M and Berntsson T. (2013) Hydrogen for oil refining via biomass indirect steam gasification: Energy and environmental targets. Clean Technologies and Environmental Policy 15: 501-512.

Bridgwater AV. (2012) Review of fast pyrolysis of biomass and product upgrading. Biomass and Bioenergy 38: 68-94.

Broekhoff D, McCormick M, Murtishaw S, et al. (2007) The Greenhouse Gas Protocol Guidelines for Quantifying GHG Reductions from Grid-Connected Electricity Projects. World Resources Institute. Available at: http://www.ghgprotocol.org/files/ghgp/electricity_final.pdf.

Buergler T and Di Donato A. (2009) Biomass gasification for DRI production. Revue de Metallurgie. Cahiers D'Informations Techniques 106: 429-433.

Caffall C. (1995) Learning form experience with Energy Management in Industry. CADDET Analyses Series No. 17: CADDET Sittard, the Netherlands.

Cagno E and Trianni A. (2013) Exploring drivers for energy efficiency within small- and medium-sized enterprises: First evidences from Italian manufacturing enterprises. Applied Energy 104: 276-285.

Cagno E, Worrell E, Trianni A, et al. (2013) A novel approach for barriers to industrial energy efficiency. Renewable and Sustainable Energy Reviews 19: 290-308.

CEPCI. (2011) Chemical Engineering Plant Cost Index. Available at: www.che.com/pci/.

Chalmers Energy Centre. (2007) Biokombi Rya biomass gasification project - Final report [Biokombi Rya - Slutrapport från ingående delprojekt]. CEC Report No 2007:3, Gothenburg: Chalmers University of Technology [in Swedish].

Chen CL, Ho CE and Yau HT. (2012) Performance Analysis and Optimization of a Solar Powered Stirling Engine with Heat Transfer Considerations. Energies 5: 35733585. 
Christoffersen LB, Larsen A and Togeby M. (2006) Empirical analysis of energy management in Danish industry. Journal of Cleaner Production 14: 516-526.

Chubb D. (2007) Fundamentals of Thermophotovoltaic Energy Conversion, Amsterdam, NLD Elsevier Science \& Technology.

Cool Energy Inc wcc. (2013) Available at: www.coolenergyinc.com. (accessed 25 April, 2013).

Council of the European Union. (1996) Council directive 96/61/EC. Official Journal L 257.

Crook AW. (1994) Profiting from Low-grade Heat. The Watt Committee on Energy, Report No. 26, London, United Kingdom: The Institution of Electrical Engineers.

CSE. (2012) What are the factors influencing energy behaviours and decision-making in the non-domestic sector? - A Rapid Evidence Assessment. Oxford, U.K.: Centre for Sustainable Energy, Department of Energy and Climate Change. Available at: https://www.gov.uk/government/uploads/system/uploads/attachment_data/file/656 01/6925-what-are-the-factors-influencing-energy-behaviours.pdf.

De Groot HLF, Verhoef ET and Nijkamp P. (2001) Energy saving by firms: Decisionmaking, barriers and policies. Energy Economics 23: 717-740.

Deming WE. (2000) Out of the crisis: The MIT Press, Massachusetts.

Dotzauer E. (2010) Greenhouse gas emissions from power generation and consumption in a nordic perspective. Energy Policy 38: 701-704.

EEA. (2012) Energy efficiency and energy consumption in industry (ENER 025) Assessment. Available at: http://www.eea.europa.eu/data-andmaps/indicators/energy-efficiency-and-energy-consumption-6/assessment. (accessed 15 November, 2013).

EIA. (2013) International Energy Outlook 2013. DOE/EIA-0484(2013): U.S. Energy Information Administration.

Eichhammer W. (2004) Industrial Energy Efficiency. In: Cutler J (ed) Encyclopedia of Energy. San Diego, California: Elsevier Academic Press, 383 -393.

Ekerot S. (2000) Jernkontoret's educational package part 2 - Iron and steelmaking: Iron ore based process metallurgy. [Jernkontorets utbildningspaket del 2 - Järn- och stålframställning: Malmbaserad processmetallurgi.]. Jernkontoret. Available at: www.jernkontoret.se/ladda_hem_och_bestall/publikationer/stal_och_stalindustri/i ndex.php [in Swedish].

Electropaedia. (2014) Available at: http://www.mpoweruk.com/stirling_engine.htm. (accessed 5 February, 2014).

Engvall K, Kusar H, Sjöström K, et al. (2011) Upgrading of raw gas from biomass and waste gasification: Challenges and opportunities. Topics in Catalysis 54: 949-959.

EPA. (2011) Climate Change - Overview of Greenhouse Gases. Available at: http://www.epa.gov/climatechange/ghgemissions/gases.html. (accessed 19 November, 2013).

Ericsson K. (2009) Introduction and development of the Swedish district heating system Critical factors and lessons learned. Report as a part of the IEE project "Policy development for improving RES-H/C penetration in European Member States”, Lund, Sweden: Lund University. Available at: http://lup.lub.lu.se/luur/download?func=downloadFile\&recordOId=1384351\&file OId $=1384353$.

European Commission. (2010) Final Report of the SET-Plan workshop on Technology Innovations for Energy Efficiency and Greenhouse Gas (GHG) emissions reduction in the Iron and Steel Industries in the EU27 up to 2030. Available at: 
http://setis.ec.europa.eu/newsroom-items-folder/report-of-set-plan-workshop-oniron-and-steel-1/Final\%2520\%2520Report\%2520of\%2520SET-

Plan\%2520workshop\%2520on\%2520Iron\%2520and\%2520Steel.pdf/view.

European Commission. (2013) Climate action - the EU emissions trading system.

Available at: http://ec.europa.eu/clima/policies/ets/. (accessed 11 october, 2013).

European Parliament. (2001) EU Directive 2001/77/EC.

European Parliament C. (2009) Directive 2009/28/EC on the promotion of the use of energy from renewable sources. L140: Official Journal of the European Union.

Available at: http://eur-

lex.europa.eu/LexUriServ/LexUriServ.do?uri=CELEX:32009L0028:EN:NOT.

European Parliament C. (2010) Directive 2010/75/EU on industrial emissions (integrated pollution prevention and control). Official Journal of the European Union Available at: http://eur-

lex.europa.eu/LexUriServ/LexUriServ.do?uri=CELEX:32010L0075:EN:NOT.

European Parliament C. (2012) Directive 2012/27/EU on energy efficiency. L315:

Official Journal of the European Union. Available at: http://eur-

lex.europa.eu/JOHtml.do?uri=OJ:L:2012:315:SOM:EN:HTML.

Eurostat. (2013) Europe 2020 indicators. Available at:

http://epp.eurostat.ec.europa.eu/portal/page/portal/europe_2020_indicators/headlin e_indicators. (accessed 19 November, 2013).

Fahlén E and Ahlgren EO. (2009) Assessment of integration of different biomass gasification alternatives in a district-heating system. Energy 34: 2184-2195.

Feliciano-Bruzual C and Mathews JA. (2013) BIO-PCI, charcoal injection in blast furnaces: State of the art and economic perspectives. Revista de Metalurgia 49: 458-468.

Ferrari C, Melino F, Pinelli M, et al. (2014) Thermophotovoltaic energy conversion: Analytical aspects, prototypes and experiences. Applied Energy 113: 1717-1730.

Fleiter T, Worrell E and Eichhammer W. (2011) Barriers to energy efficiency in industrial bottom-up energy demand models-A review. Renewable and Sustainable Energy Reviews 15: 3099-3111.

Frederiksen S and Werner S. (2013) District heating and cooling: Studentlitteratur AB, Lund.

Ghanbari H, Helle M, Pettersson F, et al. (2011) Optimization Study of Steelmaking under Novel Blast Furnace Operation Combined with Methanol Production. Industrial \& Engineering Chemistry Research 50: 12103-12112.

Ghanbari H, Helle M and Saxen H. (2012) Process integration of steelmaking and methanol production for suppressing CO2 emissions-A study of different auxiliary fuels. Chemical Engineering and Processing 61: 58-68.

Goswami DY and Kreith F. (2007) Energy Conversion: CRC Press.

Gupta RC. (2003) Woodchar as a sustainable reductant for ironmaking in the 21st century. Mineral Processing \& Extractive Metallurgy Review 24: 203-231.

Gutiérrez Trashorras AJ, Álvarez EÁ, Río González JL, et al. (2013) Design and evaluation of a heat recuperator for steel slags. Applied Thermal Engineering 56: 11-17.

Hasanbeigi A, Menke C and du Pont P. (2010) Barriers to energy efficiency improvement and decision-making behavior in Thai industry. Energy Efficiency 3: 33-52.

Hasanbeigi A, Morrow W, Sathaye J, et al. (2013) A bottom-up model to estimate the energy efficiency improvement and $\mathrm{CO} 2$ emission reduction potentials in the Chinese iron and steel industry. Energy 50: 315-325. 
Held J. (2012) Gasification - Status and technology. Report No. SGC 240: Swedish Gas Centre. Available at: http://www.sgc.se/ckfinder/userfiles/files/SGC240.pdf.

Helle H, Helle M, Pettersson F, et al. (2010) Optimisation study of ironmaking using biomass. Ironmaking \& Steelmaking 37: 590-598.

Helle H, Helle M, Saxén H, et al. (2009) Mathematical optimization of ironmaking with biomass as auxiliary reductant in the blast furnace. Isij International 49: 13161324.

Hellsmark HRA. (2010) Unfolding the formative phase of gasified biomass in the European Union:The role of system builders in realising the potential of secondgeneration transportation fuels from biomass. Environmental System Analysis, Department of Energy and Environment. Gothenburg, Sweden: Chalmers University of Technology.

Heyne S and Harvey S. (2013) Assessment of the energy and economic performance of second generation biofuel production processes using energy market scenarios. Applied Energy 101: 203-212.

IEA. (2010) Energy Technology Perspectives 2010 - Scenarios \& Strategies to 2050, France: International Energy Agency.

IEA. (2011) World Energy Outlook 2011.

IEA. (2012a) CO2 emissions from fuel combustion: Highlights. International Energy Agency.

IEA. (2012b) Energy in brief: What is shale gas and why is it important? Available at: http://www.eia.gov/energy_in_brief/article/about_shale_gas.cfm.

IEA. (2013a) Energy Technology Perspectives: Scenarios \& Strategies to 2050, Fact Sheet Industry. Available at:

http://www.iea.org/publications/freepublications/publication/industry.pdf. (accessed 18 November, 2013).

IEA. (2013b) Key World Energy Statistics. The International Energy Agency.

International Organization for Standardization. (2011) Win the energy challenge with ISO 50001. Available at: www.iso.org/iso/iso_50001_energy.pdf. (accessed 12 June, 2013).

Isaksson J, Pettersson K, Mahmoudkhani M, et al. (2012a) Corrigendum to “Integration of biomass gasification with a Scandinavian mechanical pulp and paper mill Consequences for mass and energy balances and global CO2 emissions” [Energy 44 (2012) 420-428]. Energy 47: 636.

Isaksson J, Pettersson K, Mahmoudkhani M, et al. (2012b) Integration of biomass gasification with a Scandinavian mechanical pulp and paper mill - Consequences for mass and energy balances and global CO 2 emissions. Energy 44: 420-428.

Ivner J and Helgstrand A. (2011) Environmental aspects on substitution of conventional heat production with industrial excess heat-an analysis of potentials in Östergötland and Örebro county [Miljöaspekter på ersättning av konventionell värmeproduktion med industriell restvärme - analys av potential i Östergötland och Örebro län]. Report No. LIU-IEI-R-11/0146-SE, Linköping University. Available at: http://liu.divaportal.org/smash/get/diva2:452742/FULLTEXT01.pdf. [in Swedish]

Jaffe AB and Stavins RN. (1994) The energy-efficiency gap What does it mean? Energy Policy 22: 804-810.

Janssen R, Turhollow AF, Rutz D, et al. (2013) Production facilities for secondgeneration biofuels in the USA and the EU - current status and future perspectives Biofuels, Bioproducts and Biorefining 7: 647-665. 
Jernkontoret. (2007) Jernkontoret's Energy handbook: Table of heating value and density for some common fuels [Jernkontorets Energihandbok: Tabell över värmevärde och densitet för några vanliga bränslen]. Available at:

http://www.energihandbok.se/x/a/d/tabell+\%C3\%B6ver+v\%C3\%A4rmev\%C3\% A4rde+och+densitet/Tabell-over-varmevarde-och-densitet-for-nagra-vanligabranslen.html [in Swedish]. (accessed 17 November, 2013).

Jernkontoret. (2013a) Energy Research Programme 2006-2011. Available at: http://www.jernkontoret.se/english/research/energy_research_programme/index.p hp. (accessed 27 November, 2013).

Jernkontoret. (2013b) Energy, Energy supply. Available at: http://www.jernkontoret.se/english/energy_and_environment/Energy_energy_sup ply/index.php. (accessed 15 November, 2013).

Jernkontoret. (2014a) Jernkontoret - the Swedish Steel Producers' Association. Available at: www.jernkontoret.se/english/index.php. (accessed 12 February, 2014).

Jernkontoret. (2014b) Production. Available at: http://www.jernkontoret.se/english/steel_industry/statistics/_Production/index.php . (accessed 7 February, 2014).

Jernkontoret. (2014c) Production plants. Available at: http://www.jernkontoret.se/english/steel_industry/Companies/Production_plants/i ndex.php. (accessed 7 February, 2014).

JISF. (2011) Japan iron and steel federation. Available at: www.jisf.or.jp/course50/outline/index_en.html (accessed 14 May, 2013).

Johansson D. (2013) System studies of different CO2 mitigation options in the oil refining industry: Post-combustion $\mathrm{CO} 2$ capture and biomass gasification. Heat and Power Technology, Department of Energy and Environment. Gothenburg, Sweden: Chalmers University of Technology.

Johansson D, Franck PT and Berntsson T. (2012) Hydrogen production from biomass gasification in the oil refining industry - A system analysis. Energy 38: 212-227.

Johansson MT and Söderström M. (2013) Electricity generation from low temperature industrial excess heat - an opportunity for the steel industry. Energy Efficiency.

Jørgensen F, Hyland P and Busk Kofoed L. (2008) Examining the role of human resource management in continuous improvement. International Journal of Technology Management 42: 127-142.

Kautto N, Arasto A, Sijm J, et al. (2012) Interaction of the EU ETS and national climate policy instruments - Impact on biomass use. Biomass and Bioenergy 38: 117-127.

Keveney M. (2013) Animated engines. Available at: http://www.animatedengines.com/index.html. (accessed 20 November, 2013).

Knoef H and Ahrenfeldt J. (2005) Handbook biomass gasification Enschede : BTG Biomass Technology Group.

Kvale S. (1996) Interviews: An introduction to qualitative research interviewing, California: Sage Publications Inc.

Laudal Iversen H and Gøbel B. (2005) Update on gas cleaning technologies. In: Knoef HAM (ed) Handbook: Biomass Gasification. The Netherlands: BTG biomass technology group.

Law R, Harvey A and Reay D. (2013) Opportunities for low-grade heat recovery in the UK food processing industry. Applied Thermal Engineering 53: 188-196.

Lindeström L, Löfblad G and Löfblad E. (2008) Environmental impact assessment report with regard to increased production at SSAB Luleå [Miljökonsekvensbeskrivning gällande ökad produktion vid SSAB Luleå]. Svensk MKB and Profu. Available at: 
http://www.ssab.com/global/documents/environment/bilaga\%20d\%20mkb\%20me d\%20bilagor\%20081104.pdf. [in Swedish]

Lindmark S. (2005) The Role of Absorption Cooling for Reaching Sustainable Energy Systems. Stockholm, Sweden: Royal Institute of Technology.

Ljungstedt H, Pettersson K and Harvey S. (2013) Evaluation of opportunities for heat integration of biomass-based Fischer-Tropsch crude production at Scandinavian kraft pulp and paper mill sites. Energy 62: 349-361.

Loeffler D and Anderson N. (2014) Emissions tradeoffs associated with cofiring forest biomass with coal: A case study in Colorado, USA. Applied Energy 113: 67-77.

Lulekraft AB. (2010) Available at: www.lulekraft.se/index.php?PAGEID=1\&SUBPAGEID=11. (accessed 30 April, 2010).

Lundgren J, Asp B, Larsson M, et al. (2008) Methanol production at an integrated steel mill. 18th International Congress of Chemical and Process Engineering. Prague, Czech Republic.

Lundgren J, Ekbom T, Hulteberg C, et al. (2013) Methanol production from steel-work off-gases and biomass based synthesis gas. Applied Energy 112: 431-439.

Minea AA. (2012) Advances in Industrial Heat Transfer: CRC Press.

Ministry of the Environment. (1998) Constitution on environmental hazardous activities and health. 1998:899.

Moriarty P and Honnery D. (2012) What is the global potential for renewable energy? Renewable and Sustainable Energy Reviews 16: 244-252.

Morrow Iii WR, Hasanbeigi A, Sathaye J, et al. (2013) Assessment of energy efficiency improvement and CO2 emission reduction potentials in India's cement and iron \& steel industries. Journal of Cleaner Production.

Moya JA and Pardo N. (2013) The potential for improvements in energy efficiency and $\mathrm{CO} 2$ emissions in the EU27 iron and steel industry under different payback periods. Journal of Cleaner Production 52: 71-83.

Muench S and Guenther E. (2013) A systematic review of bioenergy life cycle assessments. Applied Energy 112: 257-273.

Nilsson J. (2003) Heat recovery from cooling beds in the iron and steel industry: heat from the cooling beds-100 times better than solar [Värmeåtervinning från svalbäddar inom järn- och stålindustrin: Värme från svalbäddar-100 gånger bättre än solvärme!]. Report No D809, Stockholm, Sweden: Jernkontoret. [in Swedish]

Niska J, Grip C-E and Mellin P. (2013) Investigating Potential Problems and Solutions of Renewable Fuel Use in Steel Reheating Furnaces. The Finnish and Swedish National Committees: Finnish - Swedish Flame Days 17th-18th April, 2013. Jyväskylä, Finland: International Flame Research Foundation.

Ogriseck S. (2009) Integration of Kalina cycle in a combined heat and power plant, a case study. Applied Thermal Engineering 29: 2843-2848.

Palm J and Thollander P. (2010) An interdisciplinary perspective on industrial energy efficiency. Applied Energy 87: 3255-3261.

Pardo N and Moya JA. (2013) Prospective scenarios on energy efficiency and CO2 emissions in the European Iron \& Steel industry. Energy 54: 113-128.

Persson C and Olsson J. (2002) Comparison of various co-generation technologies [Jämförelse mellan olika kraftvärmeteknologier]. Report No SGC 128, Malmö, Sweden: Swedish Gas Technology Centre. [in Swedish] 
POSCO. (2013) Climate Change Policy. Available at: http://www.posco.co.kr/homepage/docs/eng2/html/sustain/environ/s91d1050150c. jsp. (accessed 18 November, 2013).

Qiu K and Hayden ACS. (2014) Direct thermal to electrical energy conversion using very low bandgap TPV cells in a gas-fired furnace system. Energy Conversion and Management 79: 54-58.

Remer D and Chai L. (1990) Design cost factors for scaling-up engineering equipment. Chemical Engineering and Processing 86: 77-82.

Remus R, Aguado-Monsonet MA, Roudier S, et al. (2013) Best Available Techniques (BAT) Reference Document for Iron and Steel Production. Report No. EUR 25521, Luxemburg: European Commission. Available at: Available at: http://eippcb.jrc.ec.europa.eu/reference/BREF/IS_Adopted_03_2012.pdf.

Rezaie B and Rosen MA. (2012) District heating and cooling: Review of technology and potential enhancements. Applied Energy 93: 2-10.

Rezaiyan J and Cheremisinoff NP. (2005) Gasification Technologies: A Primer for Engineers and Scientists, Boca Raton, USA: CRC Press, Taylor \& Francis Group.

Rogdakis ED, Antonakos GD and Koronaki IP. (2012) Thermodynamic analysis and experimental investigation of a Solo V161 Stirling cogeneration unit. Energy 45: 503-511.

Rohdin P and Thollander P. (2006) Barriers to and driving forces for energy efficiency in the non-energy intensive manufacturing industry in Sweden. Energy 31: 15001508.

Rohdin P, Thollander P and Solding P. (2007) Barriers to and drivers for energy efficiency in the Swedish foundry industry. Energy Policy 35: 672-677.

Rowe DM. (1995) CRC Handbook of thermoelectrics: CRC Press.

Rydstrand M, Martin V and Westermark M. (2004) Heat-driven cooling [Värmedriven kyla]. FOU 2004:112, Stockholm, Sweden: Swedish District Heating Association. [in Swedish]

Sandvik AB. (2012) Sandvik årsredovisning 2012. Available at: http://www.sandvik.com/Global/Local\%20files/Sweden/Investerare/\%C3\%85rsre dovisningar/\%C3\%85rsredovisning\%202012.pdf [in Swedish].

Sardianou E. (2008) Barriers to industrial energy efficiency investments in Greece. Journal of Cleaner Production 16: 1416-1423.

SCB. (2013) Kommunal och regional energistatistik [Municipal and regional energy statistics]. Available at: http://www.scb.se/Pages/ProductTables 24632.aspx [in Swedish]. (accessed 7 November, 2013).

Sköldberg H and Unger T. (2008) Effects of changes in electricity use/electricity production [Effekter av förändrad elanvändning/elproduktion]. Report No. 08:30 Elforsk [in Swedish].

Sköldberg H, Unger T and Olofsson M. (2006) Marginal electricity and environmental evaluation of electricity [Marginalel och miljövärdering av el]. Elforsk rapport 06:52, Stockholm, Sweden: Elforsk. Available at: http://www.elforsk.se/Rapporter/?rid=06_52_[in Swedish].

Sorrell S, Schleich, J., Scott, S., O’Malley, E., Trace, F., Boede, E., Ostertag, K., Radgen, P. (2000) Reducing barriers to energy efficiency in public and private organizations. Available at: www.sussex.ac.uk/Units/spru/publications/reports/barriers/final.html (accessed 12 June, 2013). 
Spellman FR. (2011) Forest-Based Biomass Energy: Concepts and Applications: CRC Press.

Srikhirin P, Aphornratana S and Chungpaibulpatana S. (2001) A review of absorption refrigeration technologies. Renewable \& Sustainable Energy Reviews 5: 343-372.

SSAB. (2012) SSAB Årsredovisning. Available at: http://mb.cision.com/Main/980/9390079/105885.pdf [in Swedish]

Statistics Sweden. (2013) Energy. Available at: www.scb.se [in Swedish]. (accessed 30 September, 2013).

Stephenson J, Barton B, Carrington G, et al. (2010) Energy cultures: A framework for understanding energy behaviours. Energy Policy 38: 6120-6129.

Stålkretsloppet. (2012) The Steel Eco-Cycle: Closing the loop in the manufacture and use of steel in society. Scientific Report D 853: The Steel Eco-Cycle

Environmental Research Programme for the Swedish Steel Industry 2004 - 2012.

Available at:

http://www.jernkontoret.se/ladda_hem_och_bestall/publikationer/stalforskning/ra pporter/D_853.pdf.

Sudhakara Reddy B. (2013) Barriers and drivers to energy efficiency - A new taxonomical approach. Energy Conversion and Management 74: 403-416.

Suopajärvi H and Fabritius T. (2012) Effects of biomass use in integrated steel plant Gate-to-gate life cycle inventory method. Isij International 52: 779-787.

Suopajärvi H and Fabritius T. (2013) Towards more sustainable ironmaking-an analysis of energy wood availability in finland and the economics of charcoal production. Sustainability (Switzerland) 5: 1188-1207.

Suopajärvi H, Pongrácz E and Fabritius T. (2013) The potential of using biomass-based reducing agents in the blast furnace: A review of thermochemical conversion technologies and assessments related to sustainability. Renewable and Sustainable Energy Reviews 25: 511-528.

Swedish District Heating Association. (2007) The district heating pipe cost report [Kulvertkostnadskatalog]. Report No. 2007:1: The Swedish district heating association, Stockholm [in Swedish].

Swedish District Heating Association. (2010) Excess heat 2010 [Överskottsvärme 2010] Excel sheet accessed through personal communication. [in Swedish] (accessed, 2010).

Swedish Energy Agency. (2009) Energy in Sweden 2008. Available at: http://213.115.22.116/System/TemplateView.aspx?p=Energimyndigheten\&view= default\&id=76dc15c9a8344575bbb75704487723ef.

Swedish Energy Agency. (2013a) Energiläget 2013 [Energy in Sweden 2013]. Available at: https://energimyndigheten.a-w2m.se/Home.mvc?ResourceId=2785 [in Swedish].

Swedish Energy Agency. (2013b) Energy in Sweden 2012. ET2012:75: Swedish Energy Agency.

Swedish Energy Agency. (2014) Different types of policy instruments [Olika typer av styrmedel]. Available at: http://www.energimyndigheten.se/Om-oss/Energi--ochklimatpolitik/Styrmedel/Olika-typer-av-styrmedel/ [in Swedish]. (accessed 21 March, 2014).

Swedish Environmental Protection Agency. (2013a) Detailed data support and diagrams [Detaljerade dataunderlag och diagram]. Available at: http://www.naturvardsverket.se/Sa-mar-miljon/Statistik-A-O/Vaxthusgaserutslapp-fran-industrins-forbranning/ [in Swedish] 
Swedish Environmental Protection Agency. (2013b) National Inventory Report Sweden 2013, Greenhouse Gas Emission Inventories 1990-2011 - Submitted under the United Nations Framework Convention on Climate Change and the Kyoto Protocol. Available at: http://www.naturvardsverket.se/upload/sa-marmiljon/statistik-a-tillo/vaxthusgaser/2013/NIR_SE_Submission_2013_Report_15_mar.pdf.

Tarrés J, Maas S, Scholzen F, et al. (2014) Simulated and experimental results on heat recovery from hot steel beams in a cooling bed applying modified solar absorbers. Journal of Cleaner Production.

Thollander P, Backlund S, Trianni A, et al. (2013) Beyond barriers - A case study on driving forces for improved energy efficiency in the foundry industries in Finland, France, Germany, Italy, Poland, Spain, and Sweden. Applied Energy 111: 636643.

Thollander P, Danestig M and Rohdin P. (2007) Energy policies for increased industrial energy efficiency: Evaluation of a local energy programme for manufacturing SMEs. Energy Policy 35: 5774-5783.

Thollander P and Ottosson M. (2008) An energy efficient Swedish pulp and paper industry - Exploring barriers to and driving forces for cost-effective energy efficiency investments. Energy Efficiency 1: 21-34.

Thollander P and Palm J. (2013) Improving Energy Efficiency in Industrial Energy Systems: An Interdisciplinary Perspective on Barriers, Energy Audits, Energy Management, Policies, and Programs, London, The U.K.: Springer.

Thollander P, Rohdin P and Moshfegh B. (2012) On the formation of energy policies towards 2020: Challenges in the Swedish industrial and building sectors. Energy Policy 42: 461-467.

Tian Y and Zhao CY. (2013) A review of solar collectors and thermal energy storage in solar thermal applications. Applied Energy 104: 538-553.

Trianni A, Cagno E, Thollander P, et al. (2013a) Barriers to industrial energy efficiency in foundries: a European comparison. Journal of Cleaner Production 40: 161-176.

Trianni A, Cagno E, Worrell E, et al. (2013b) Empirical investigation of energy efficiency barriers in Italian manufacturing SMEs. Energy 49: 444-458.

ULCOS. (2013) Available at: www.ulcos.org. (accessed 14 May, 2013).

US Department of Energy - Advanced Manufacturing Office. (2013) DOE eGuide for ISO 150001 Available at: ecenter.ee.doe.gov/EM/SPM/Pages/Step1.aspx. (accessed 4 June, 2013).

US Department of Energy. (2008) Waste Heat Recovery: Technology and Opportunities in U.S. Industry. US Department of Energy, Industrial Technologies Program. Available at:

http://www1.eere.energy.gov/manufacturing/intensiveprocesses/pdfs/waste_heat_r ecovery.pdf.

Walsh C and Thornley P. (2012) Barriers to improving energy efficiency within the process industries with a focus on low grade heat utilisation. Journal of Cleaner Production 23: 138-146.

van der Stelt MJC, Gerhauser H, Kiel JHA, et al. (2011) Biomass upgrading by torrefaction for the production of biofuels: A review. Biomass and Bioenergy 35: 3748-3762.

Velez F, Segovia JJ, Martin MC, et al. (2012) A technical, economical and market review of organic Rankine cycles for the conversion of low-grade heat for power generation. Renewable \& Sustainable Energy Reviews 16: 4175-4189. 
Wetterlund E, Pettersson K and Harvey S. (2011) Systems analysis of integrating biomass gasification with pulp and paper production - Effects on economic performance, CO2 emissions and energy use. Energy 36: 932-941.

Wetterlund E and Söderström M. (2010) Biomass gasification in district heating systems the effect of economic energy policies. Applied Energy 87: 2914-2922.

Widmark H. (2000) Jernkontoret's educational package part 3 - Iron and steelmaking: Scrap-based process metallurgy. [Jernkontorets utbildningspaket del 3 - Järn- och stålframställning: Skrotbaserad processmetallurgi.]. Jernkontoret. Available at: www.jernkontoret.se/ladda_hem_och_bestall/publikationer/stal_och_stalindustri/i ndex.php [in Swedish].

Villar A, Arribas JJ and Parrondo J. (2012) Waste-to-energy technologies in continuous process industries. Clean Technologies and Environmental Policy 14: 29-39.

WMO. (2013) The State of Greenhouse Gases in the Atmosphere Based on Global Observations through 2012. No. 9: WMO Greenhouse Gas Bulletin. Available at: http://www.wmo.int/pages/prog/arep/gaw/ghg/documents/GHG_Bulletin_No.9_e n.pdf.

World Energy Council. (2008) Energy Efficiency Policies around the World: Review and Evaluation Available at:

http://www.worldenergy.org/documents/energyefficiency_final_online.pdf.

World Steel Association. (2008) Fact Sheet - Energy. Available at: http://www.worldsteel.org/dms/internetDocumentList/fact-sheets/Factsheet_Energy/document/Fact\%20sheet_Energy.pdf. (accessed 15 November, 2013).

World Steel Association. (2012a) Statistics. Available at: www.worldsteel.org. (accessed 2 October, 2013).

World Steel Association. (2012b) Sustainibility indicators. Available at: http://www.worldsteel.org/steel-by-topic/sustainable-steel/sustainabilityindicators.html. (accessed 15 November, 2013).

Worldsteel Association. (2014) Crude steel production. Available at: http://www.worldsteel.org/statistics/crude-steel-production.html. (accessed 7 February, 2014).

Worrell E, Blinde P, Neelis M, et al. (2010) Energy efficiency improvement and cost saving opportunities for the U.S. iron and steel industry - An ENERGY STAR guide for energy and plant managers Report No. LBNL-4779E: Ernest Orlando Lawrence Berkeley National Laboratory, University of California. Available at: http://www.energystar.gov/ia/business/industry/Iron_Steel_Guide.pdf.

Xu CB and Cang DC. (2010) A Brief Overview of Low CO2 Emission Technologies for Iron and Steel Making. Journal of Iron and Steel Research International 17: 1-7.

Zeng SJ, Lan YX and Huang J. (2009) Mitigation paths for Chinese iron and steel industry to tackle global climate change. International Journal of Greenhouse Gas Control 3: 675-682.

Zhang H, Dong L, Li HQ, et al. (2013a) Investigation of the residual heat recovery and carbon emission mitigation potential in a Chinese steelmaking plant: A hybrid material/energy flow analysis case study. Sustainable Energy Technologies and Assessments 2: 67-80.

Zhang H, Wang H, Zhu X, et al. (2013b) A review of waste heat recovery technologies towards molten slag in steel industry. Applied Energy 112: 956-966.

Åbyhammar T and Östergård K. (2001) Mapping the energy use and energy efficiency potential at Sandvik Steel AB, Sandviken [Kartläggning av energianvändning och 
energieffektiviseringspotential vid Sandvik Steel AB, Sandviken]. Vattenfall AB. [in Swedish] 


\section{Appendix 1}

\section{Interview guide: Energy managers at Swedish iron and steel companies}
A. How many employees does your company have?
B. How much energy does your company use every year?
C. How much do you produce every year?
D. What distinguishes your company from other steel companies in Sweden?
a) Products
b) Production process
c) Energy utilisation

E. How long have you been an employee at this company?

a) What did you do before?

F. What education do you have?

\section{Energy work at the company}

2) First, can you describe your job assignments?

a) What does it mean exactly?

b) Do you work full time with energy issues?

3) How many at your company work with energy issues?

a) Give examples of what they are working with.

b) In summary, how many full-time positions are working with energy issues?

4) Can you tell me about energy efficiency measures that your company has done?

a) In the production processes

b) In the support processes

c) Information to change behaviour of employees

5) In what way does your company work with energy issues?

a) Do you think the company prioritizes these issues?

i) Can you give examples of how the company prioritizes/does not prioritize energy issues? 
6) At your company, can you describe the process of decision-making with regard to energy efficiency operations?

a) Who provides proposals for energy efficiency measures?

b) Who decides what measures should be implemented?

c) Is there a specific quantity (sum) of money reserved for energy efficiency measures or do you have to ask for money every time?

d) Is it always the same people who initiates decisions or does it vary? Give examples.

e) Is it always the same people who makes decisions or does it vary? Give examples.

f) Are employees encouraged to make suggestions for energy efficiency measures?

i) How? Why or why not?

7) Do you think that the company puts a reasonable amount of resources on energy issues?

a) Do you have resources to implement your ideas?

b) In what way?

c) What do you miss?

8) Do you feel that the management listens to you?

a) Tell me about an energy efficiency measure that you have carried through?

i) Why do you choose this?

b) Tell me about an action that you think should be introduced, but which has been rejected by the management.

i) What was the motivation for rejection?

9) What barriers to improved energy efficiency have you experienced?

10) If you look generally, what energy efficiency measures do you think could be done at your company?

11) What is your company's “energy vision”?

a) At your company, how does the future in the energy field look like?

12) Can you influence long-term strategic investments?

13) Do you feel that there is a difference in how energy issues are prioritised now, compared to when you started working at the company?

a) In what way?

14) Do you think suppliers can deliver energy-efficient equipment and systems?

a) In what way?

b) Why not?

\section{Jernkontoret: Energy council}

15) How long have you been a member of the Energy Council?

16) Can you describe the Energy Council's function?

17) Can you describe a typical meeting?

a) Are all members always invited?

b) Where do you meet?

c) What does the meeting agenda look like? 
i) Fixed/Varies

ii) Who decides the agenda?

d) What issues do you discuss at the meeting?

e) How often do you have meetings?

18) Do you find it satisfying to be a member?

a) In what way?

\section{Jernkontoret: Energy Network}

19) Are you a member of the Energy Network "ENET-Steel”?

a) For how long have you been a member?

b) Are you active in the network?

i) In what way?

20) Can you describe the network's function?

21) How often does the network get together?

22) Can you tell me something about how such a get-together may appear?

a) How many people usually come?

b) What do you do on the get-together?

c) Where do you meet?

23) Does the network have other activities besides these get-togethers?

a) Study visits?

b) Do you visit each other's companies?

24) How do you feel that the network works?

a) Is it possible to share information and experience?

i) Are there times when this is impossible due to confidentiality?

25) Can you tell me about an occasion when you experienced that you were helped by being a member of the network?

a) In what way were you helped?

26) Are there occasions when you think that the network has being a barrier in your work?

27) Do you use the chat-site on the internet?

a) In what way?/Why not?

b) How often?

c) Do you think that you get help and advice here?

28) Do you meet with other energy managers/coordinators in other contexts?

a) Why is that?

b) Who initiates this?

29) Do you have energy-related cooperation with companies outside Jernkontoret?

a) What kind of cooperation?

30) Is there anything else that you wish to add? Anything that you think that I should have asked you? 



\section{Appended Papers}

The articles associated with this thesis have been removed for copyright reasons. For more details about these see:

http://urn.kb.se/resolve?urn=urn:nbn:se:liu:diva-105849 